ks. Tadeusz Matras

\title{
BIBLIOGRAFIA ZAWARTOŚCI „RUCHU BIBLIJNEGO I LITURGICZNEGO" W LATACH 1948-1998
}

\begin{abstract}
ARTYKUŁY
ABRAMEK Rufin Józef OSPPE, Nowy akcent we współczesnej interpretacji Magnifikat (Łk 1, 46-55). 4 (1987) 342-354

ALICKI Wiesław ks., Internet dla biblisty. 1 (1998) 50-57

ALSTEENS André OSB, Liturgia i teologia a wyczucie teraźniejszości. 4-5 (1969) 226-239
\end{abstract}

ALTBAUER Moshé, Nieznany wariant tekstowy Łk 24, 9.4 (1980) 216-219

ARNDT Marian OFM, Lokalizacja biblijnego Mefaat. 1 (1988) 59-74

- Nowe odkrycia archeologiczne w rejonie Góry Nebo. 1 (1989) 42-51

AUGUSTYNEK Władysław SJ, „Arena sportowa” w listach św. Pawła. 1 (1953) 172174

BAJEROWA Irena, Bronię „Bogurodzicy”. 6 (1959) 551-558

BAKSIK Sylwester ks., Geneza nowohebrajskiego języka. 4-6 (1956) 301-302

- Religie na Bliskim Wschodzie w cyfrach. 1 (1959) 71

— Śp. ks. dr Paweł Szczygieł MSC. 2 (1951) 230-233

BALTER Lucjan SAC, Nadzwyczajny szafarz Eucharystii. 4 (1978) 207-214

B[AŁTOWSKI] ks., Gdzie apostołowie byli w czasie męki Jezusa? 1-3 (1956) 82-92

BANAK Jerzy ks., „Tak bowiem czyniąc, węgle żarzące zgromadzisz na jego głowę” (Rz 12, 20). 4-5 (1971) 205-209

BAR Joachim Roman OFMConv, Droga do beatyfikacji królowej Jadwigi. 1 (1987) 58-63

- Polskie procesy kanonizacyjne i beatyfikacyjne. 5 (1958) 418-447

BARCKI Kazimierz ks., Pojęcie Boga w księdze Daniela. 4 (1957) 241-247

— Wykopaliska w Nazaret. 4-5 (1956) 295-298

B[ARDECKI] A[ndrzej] ks., Postulaty w nauczaniu liturgiki. 1 (1954) 41-44

BARTEL Władysław, Z dziejów kanonistyki na Wydziale Prawa Uniwersytetu Jagie 1lońskiego w XVIII wieku. 2 (1966) 114-131 
BARTKOWICZ Izabela, Między historią a Biblią — O „Legionie” S. Wyspiańskiego. 3 (1995) 200-209

BARTKOWSKI Bolesław SDB, Pamięci księdza profesora Hieronima Feichta. 3 (1967) 183-185

BARTNICKI Roman ks., Eucharystia w Bożym planie zbawienia. 1 (1997) 2-16; 2 (1997) 119-127

- Najnowsze rozwiązania problemu synoptycznego. 1 (1989) 28-41

- Prorok z Nazaretu w Galilei (Mt 21, 11). 4-5 (1972) 213-218

- Redakcyjna praca Mateusza w Mt 9, 35-11, 1.4 (1987) 280-288

- Strukturalizm i semiotyka w badaniach nad Ewangeliami. 1 (1992) 6-20

BEDYCHE Małgorzata, Jerozolima w przepowiadaniu Trito-Izajasza. 3 (1996) 170177

BEDNARZ Michał ks., Ks. Walerian Serwatowski - wybitny biblista polski XIX wieku. 3 (1986) 274-278

- Odkrycia Jerycha Heroda Wielkiego. 6 (1980) 325-331

- O. Roland de Vaux OP (1903-1971). 2-3 (1973) 148-149

BEISSER Friedrich, Marcina Lutra rozumienie Pisma świętego. 5 (1983) 406-411

BERWALDT Jacek, W 250. rocznicę śmierci Grzegorza Gerwazego Gorczyckiego. 4 (1984) 335-337

BIALIC Dominik ks., Niektóre zboczenia liturgii mszalnej w świetle reformy Soboru Trydenckiego. 1 (1949) 49-57

Bibel und Kirche. 4 (1952) 376

BIEDA Ignacy SJ, Skuteczność „ex opera operato” Mszy świętej i sakramentów i jej stosunek do „opus operantis”. 3 (1967) 135-145

BIELAS Lucjan ks., Dziecko przed urodzeniem w starożytnym świecie pogańskim. 13 (1991) 37-41

BIELAWSKI Maciej OSB, Pico della Mirandola i Henri Lubac (zapis procesu lektury i rozpoznawania). 4 (1995) 285-290

BIELECKI Stanisław ks., Nowotestamentalne ujęcie terminu kairos. 2-6 (1992) 57-65

BISTA Stanisław ks., Przepisy prawa kanonicznego w zakresie budownictwa ko ścielnego. 3 (1984) 217-225

BLACHNICKI Franciszek ks., Katecheza o Mszy świętej w świetle soborowej odnowy liturgii. 4-5 (1966) 243-254

- Pastoralne założenia Dyrektorium a nasze możliwości. 2-3 (1977) 146148

BŁASZKIEWICZ Tadeusz bp, Słowo na zakończenie sympozjum. 5 (1986) 430-433 
BÖCHER Otto, Niebiańskie Jeruzalem. Spostrzeźenie na temat eklezjologii i eschatologii Apokalipsy św. Jana. 4 (1988) 330-336

BOGACZ Roman ks., Ks. prof. Józef Archutowski (1879-1944) — życie i działalność na tle epoki. 1 (1995) 34-38

BOGUNIOWSKI Józef Waclaw SDS, Błogosławieństwo wody. 2 (1993) 78-85

- Collectarium breviario - rituale Ecclesiae cathedralis cracoviensis. 4 (1995) 271-274

— Kongres wykładowców liturgiki w Holandii (1988). 5-6 (1989) 398

- Mensa Domini et ecclesiae. Refleksje nad terminologią ołtarza katolickiego. 2-6 (1992) 86-90

- Międzynarodowa sesja naukowa wykładowców liturgiki w Brixen (1992). 2 (1993) 103-104

— Sympozjum liturgiczne w Bambergu (1995). 1 (1996) 55

- Zjazdy liturgistów obszaru języka niemieckiego (AKL) w latach 19641988. 1-2 (1990) 89-91

BOJKO Stanisław SJ, Sesja poświęcona ks. J. Wujkowi w Wagrowcu (1991). 1 (1993) 35-36

BOLCZYK Henryk ks., Charyzmatyczny wymiar posługi kapłańskiej ks. Wojciecha Danielskiego. 5 (1986) 454-458

BOLIŃSKI Henryk SJ, CHOLEWIŃSKI Alfred SJ, PAWLICKI Tadeusz SJ, Komentarz liturgiczny na okres Wielkiego Postu. 4-5 (1966) 261-296

BOMBA Władysław CM, Chrzest wielu dzieci w czasie Mszy świętej (Próba rozwiązania praktycznego). 1 (1973) 41-44

- Duszpasterskie aspekty obrzędu chrztu dzieci. 1 (1973) 39-41

BORKOWSKI Aureliusz OFM, O Grobie Bożym. (1149-1949). 3 (1949) 165-168

BOROWICZ Kazimierz ks., Canticum Moysi et canticum Agni (Ap 15, 3). 2 (1964) $81-87$

— „Drzewa” i „rzeki” w ogrodzie Eden w świetle egzegezy mistycznej hebrajskiej (Gen II-III). 3 (1951) 250-267

- Hebrajska etymologia słowa „Missa”. 5-6 (1952) 445-469

- Mistyka hebrajska u św. Pawła i w Apokalipsie św. Jana. 3-4 (1950) 187206

- Obraz Chrystusa na tzw. Świętym Całunie z Turynu. 5-6 (1948) 287-305

- Resurectio prima - resurectio secunda (Ez 37, 1-14; Iz 26, 13-21). 5-6 (1963) 235-251

BOROWSKI Władysław CRL, Ciemięzcy zostaną ukarani (Iz 3, 1-15). 4-5 (1972) $242-248$ 
- Dwie godziny biblijne pt. Proroctwo Izajasza (1, 1-31). 4-5 (1967) 266278

— Dzień Jahwe (Iz 2, 12-21) — godzina biblijna. 4-5 (1968) 291-296

- Kantyk Mojżesza i Miriam (Wj 15, 1-21). 5-6 (1976) 254-259

- Mowa Izajasza (3, 16-4, 1). 4-5 (1974) 252-257

- Odstępstwa ludu Bożego (Iz 2, 1-11) — godzina biblijna. 4-5 (1968) 284291

BORUC Marek ks., Ksiądz Wojciech — przyjaciel. 5 (1986) 461

BRAULIK Georg SDB, Bliskość Boga i sprawiedliwość społeczna. Rozumienie deuteronomistycznego prawa w okresie niewoli. 6 (1980) 301-307

BREZA Emil, „Pięćdziesiątnica” i nazwy podobne. 5 (1987) 417-420

BRYŃSKI Kazimierz ks., Z dziejów krzyża. 2-3 (1970) 147-152

BRZEGOWY Tadeusz ks., „A sprawiedliwy żyć będzie dzięki swej wierze”. Religijne przesłanie proroka Habakuka. 1 (1998) 7-17

— Bóg panem życia. 2 (1987) 153-159

- Chronologia epoki królewskiej w starożytnym Izraelu. 4 (1998) 261-270

- Czy warto być uczciwym? Wskazania etyczne mędrca Koheleta. 4 (1996) 221-230

- Doroczne święta pielgrzymkowe Izraela. 2 (1983) 98-115

- Eschatologia proroka Joela. 3-4 (1993) 117-128

— Jak rozumieć Pieśń nad pieśniami. 3 (1985) 185-199

- Jeruzalem miasto pokoju. Przyczynek do teologii zbawienia w psalmach. 1 (1989) 10-21

- Nielewickie kapłaństwo królestwa Izraela. 5 (1977) 227-237

- Prorok Natan i budowa świątyni. 1 (1987) 7-19

- Śp. ksiądz profesor Stanisław Łach. 1 (1984) 6-11

— Teofania eschatologiczna na Syjonie. 4 (1988) 299-306

- XIII Międzynarodowe spotkanie Society of Biblical Literature (Budapeszt 1995). 1 (1996) 51-52

- W dwadzieścia lat po komentarzu ks. St. Łacha do Protoewangelii. 1 (1984) 12-34

- Wybranie Jerozolimy w świetle psalmów. 5-6 (1990) 94-104

BUDZIAREK Marek., Kult relikwii w starożytnym chrześcijaństwie. 5 (1979) 276-280

BUKOWSKI Kazimierz ks., Nowy kalendarz liturgiczny. 6 (1969) 342-349

— „Święto Biblii” w Gdańsku (6-8 X 1992). 1 (1993) 36-37 
BULANDA Edward SJ, Geneza i znaczenie mitu w historii kultury. 4 (1959) 373-396; 5 (1959) 453-472

- Kult bogini-matki w religiach pogańskich a cześć Bożej Matki w chrześcijaństwie. 2 (1954) 156-176

BURZAWA Stanisław ks., Kongres mariologiczny w Lizbonie. 4-5 (1967) 293-295

- Liturgia na Pierwszym Synodzie Biskupów. 3 (1968) 159-167

- Liturgia po Soborze. 4-5 (1967) 227-234

- Międzynarodowy Tydzień Muzyki Kościelnej w Pamplonie. 4-5 (1967) 295-296

- Odnowa liturgii w Kościele francuskim. 1-2 (1968) 104-108

- Soborowa reforma liturgiczna odnową Kościoła. 4-5 (1966) 233-242

- Spotkanie w Chartres na temat „Stare kościoły w służbie liturgii posoborowej". 6 (1967) 372-373

BUXAKOWSKI Jerzy ks., O aktualizacji teologii współofiary. 2 (1959) 146-160

- O formach czynnego udziału wiernych we Mszy świętej. 4 (1962) 241254

— Śp. ks. Józef Grochocki (1894-1961). 1 (1962) 52-54

— Św. Tomasz o liturgii Mszy św. (według Komentarza do IV księgi Sentencji Piotra Lombarda). 2 (1952) 141-164; 3 (1952) 253-262

BZOWSKI Stanisław ks., Gratia plena czy gratificata? 1 (1973) 48-49

— Jak rozumieć „divina misteria” w orędziu wielkanocnym? 4-5 (1972) 268270

CARMIGNAC Jean ks., Problem semityzmów w ewangeliach synoptycznych. 6 (1987) 516-533

CHADAM Augustyn OFM, Franciszkańskie sześćsetlecie w Betlejem. 3 (1948) 167172

- Miejsce drugiego kuszenia Pana Jezusa. 4 (1948) 209-212

— Święto Bożego Narodzenia. 5-6 (1948) 276-281

— Z dziejów Kustodii Ziemi Świętej. 3-4 (1950) 250-253

CHLEWIŃSKI Zdzisław ks., Liturgista i przyjaciel. 5 (1986) 450-452

CHŁĄD Stanisław ks., Charyzmaty w Rz 12, 6-8. 1 (1986) 24-32

CHMIEL Jerzy ks., Apostolat biblijny w Austrii. 6 (1983) 533-535

- Badania onomastyczne w egzegezie biblijnej. 4 (1980) 212-215

- Biblia a kultura. 1 (1983) 33-36

- „Biblia jako Słowo Boże”. Colloqium Biblicum w Wiedniu (1982). 6 (1983) 549-551 
- Biblia slavica. 4 (1998) 313-314

- Biblia. Tradycja. Hermeneutyka. 3-4 (1993) 128-134

- Biblia we wczesnym Średniowieczu. 4 (1962) 254-255

- Biblijne pojęcie agapè jako model etyczny. 4 (1977) 181-189

- Biblijne pomniki polskiej mowy. Inicjatywy edytorskie ks. prof. Władysława Smereki. 6 (1981) 341-343

- Biblijne podstawy adhortacji apostolskiej „Catechesi tradendae”. 5 (1980) 275-279

— Biblijne podstawy encykliki Jana Pawła II „Redemptor hominis”. 6 (1979) 297-303

- Biblijny etos posłuszeństwa. 4 (1988) 353-360

- Biblijny model formacji do kapłaństwa w adhortacji apostolskiej Jana Pawła II „Pastores dabo vobis”. 1 (1993) 26-31

- Biblijny teatr Godziny Słowa Danuty Michałowskiej. 2 (1997) 144-147

- Biblistyka katolicka po Soborze Watykańskim II. W dwudziestolecie konstytucji dogmatycznej „Dei Verbum” (1965-1985). 1 (1986) 1-4

- Bóg jest miłością (1 J 4, 8-16) - godzina biblijna. 4-5 (1969) 282-288

— Bóg jest światłością (1 J 1, 5-7) — godzina biblijna. 4-5 (1969) 276-282

- Całun Turyński anno Domini 1998. 1 (1998) 47-50

- Chrystocentryczna lektura Pisma świętego. 5 (1977) 254-268

- Członkowie Papieskiej Komisji Biblijnej. 4-5 (1972) 270-272

- Człowiek ośmiu błogosławieństw. Błogosławiony Piotr Jerzy Frassatii (1901-1925). 3-6 (1990) 155-156

- Czy Pierwszy list św. Jana jest rozbudowaną homilią chrzcielną? 1 (1973) 1-3

- Czytanie Pisma świętego jako modlitwa. 1 (1978) 22-27

- Dawid w Biblii. XVII Kongres ACFEB (Lille 1997). 4 (1997) 292-293

- Deutero-Izajasz w Nowym Testamencie. IV Colloqium Biblijne w Wiedniu. 6 (1987) 514-515

- Dignus est accipere. Laudacja wygłoszona w czasie promocji o. prof dra hab. Augustyna Jankowskiego OSB doktora honoris causa Papieskiej Akademii Teologicznej w Krakowie dnia 7 grudnia 1996 r. 1 (1997) 51-56

- Dni biblijne w Lovain. 6 (1962) 376-378

- Don Giuseppe Dossetti (1913-1996) in memoriam. 3 (1997) 224-225

— Druga pielgrzymka Jana Pawła II do Ojczyzny. 5 (1983) 385-387 
- Działalność Polskiego Towarzystwa Teologicznego w Krakowie w roku 1970. 2-3 (1971) 156-157

— 25-lecie Katolickiej Federacji Biblijnej. 4 (1994) 284-285

- Dziecko poczęte według Biblii i starożytnego judaizmu. 1-3 (1991) 42-47

— 10 lat konstytucji soborowej „O Bożym Objawieniu”. 6 (1975) 266-269

- X Kongres Studiów Starego Testamentu. Colloqium Biblicum w Wiedniu (1980). 6 (1980) 355-356

- Dziesięciolecie Instytutu Ekumenicznego w Tantur k. Jerozolimy. 2 (1983) 143-147

- Edycja biblijna z okazji roku wiary. 1 (1969) 41-42

- Egzegeza biblijna a filozofia. 4 (1978) 173-178

— „Etyka w Nowym Testamencie”. Sympozjum biblijne w Lucernie (1983). 6 (1983) 552-553

- Geneza i charakter homilii sakramentalnej. 1 (1983) 21-26

- Grzech i wyzwolenie od grzechu w Nowym Testamencie. (Spotkanie w Strasburgu 1995). 2 (1995) 137-139

- Gwiazda betlejemska i data narodzin Jezusa. 3 (1996) 207

- Hermeneutyka biblijna i Magisterium Kościoła. 5 (1978) 247-252

- Hermeneutyka i sens tekstów biblijnych. 1 (1996) 44-49

- Historyczność Jezusa Chrystusa w świetle antychrzescijańskich graffiti z Herodium. 6 (1974) 337-338

- Homilia podczas koncelebrowanej Eucharystii za śp. księży profesorów Archutowskiego, Mazerskiego i Klawka. 1 (1995) 59-60

- Homilie. Rok B. I Tydzień Adwentu. 4-5 (1972) 283-295

- Homilie adwentowe na rok A. 4-5 (1971) 226-237

- Homilie (okres Bożego Narodzenia). 6 (1971) 305-313

- Homo patiens w Biblii. Na kanwie nauczania Jana Pawła II. 2 (1997) 127133

— „Idąc czyńcie uczniami wszystkie narody” (Mt 28, 19). 4-6 (1991) 127129

- Inauguracja ekumenicznego przekładu Biblii w języku polskim. 2 (1997) 160

- In memoriam prof. Karola Eistreichera. 3 (1984) 274-276

- Intencja autora jako zasada hermeneutyczna. Przyczynek do teologii natchnienia biblijnego. 1 (1979) 4-14

— Jana Kochanowskiego lektury biblijne. 6 (1984) 501-505 
— „Jeden świat dla wszystkich”. II Międzynarodowa chrześcijańsko- islamska konferencja w Wiedniu (1997). 3 (1997) 212-213

— „Każdy, kto się narodził z Boga, nie grzeszy” (1 J 3, 9; 5, 18). 3 (1985) 207-212

- Koncepcja miłości w Pierwszym liście św. Jana. 5-6 (1976) 285-294

— „Krew i woda”. Próby interpretacji J 19, 34. 6 (1977) 291-296

- Kronika biblijna. 2 (1994) 131-132; 4 (1998) 315

- Ks. Josef Schmid (1893-1975). 5-6 (1976) 311-312

- Ks. Max Zerwick SJ (1901-1975). 5-6 (1976) 311

- Ks. profesor Aleksy Klawek (1890-1969). Biblista i orientalista. 1 (1995) $52-53$

- Listy katolickie jako model przepowiadania dziś. 6 (1986) 501-504

- Materiały biblijne do homilii adwentowych. 4-5 (1970) 226-231

- Materiały biblijne do homilii żałobnych (III). 2-3 (1973) 153-157

- Materiały biblijne do homilii żałobnych. 4-5 (1972) 274-283; 6 (1972) 361-365

— Materiały do homilii. 3 (1983) 278-288; 4 (1983) 344-352

- Materiały do homilii i katechez przedślubnych. 1 (1983) 65-88; 2 (1983) $160-176$

- Materiały do homilii pierwszopiątkowych. 6 (1975) 287-294

- Materiały do homilii żałobnych. IV. 1-2 (1974) 88-95

- Mentalność biblisty. 6 (1970) 297-301

- Międzynarodowe Kolokwium „Pentecostes” w Angers (1995). 3 (1995) 217-218

- Międzynarodowe kolokwium nt. Qumran (Kraków-Mogilany 1987). 3 (1987) 231-233

- Międzynarodowy Kongres Studiów Biblijnych w Oxfordzie. 5 (1978) 275-277

- Międzynarodowy Zjazd Society Biblical Literature w Krakowie (1998). 3 (1998) 234-236

- Miłość za miłość. Homilia niedzielna. 5-6 (1976) 325-328

- Model kobiety w Biblii. Zarys hermeneutyczny. 5 (1995) 255-259

- Modele antropologiczne w interpretacji natchnienia biblijnego. 2 (1981) 81-88

- Nabożeństwa Słowa Bożego z Janem Pawłem II. 5 (1983) 411-433; 4 (1984) 340-355 
- Najstarszy kult maryjny w Nazaret. 1 (1969) 42-43

- Nauki biblijne a współczesna socjologia. Międzynarodowe seminarium interdyscyplinarne (Emmenten 1995). 2 (1996) 126-127

- „Nie wypowiedziane Przymierze?” Sympozjum biblijne w Innsbrucku (1997). 3 (1997) 210-211

- Nowa semantyka biblijna. 6 (1974) 319-327

- Nowe aspekty biblijnej wizji małżeństwa i rodziny w adhortacji apostolskiej „Familiaris consortio”. 4 (1989) 284-290

- Nowe aspekty nowej semantyki w egzegezie biblijnej. 4-5 (1975) 236

- Nowe rękopisy z Qumran. 4-5 (1969) 302-303

- Nowy doktor nauk biblijnych w Polsce. 6 (1962) 381-382

— Od „Providentissimus Deus” do „Dei Verbum”. I co dalej? 2 (1994) 106111

- Opowiadania biblijne. Aspekt genologiczny i hermeneutyczny. 1 (1988) 44-51

- O projekcie nowego wydania Biblii hebrajskiej. 5-6 (1963) 321

— 85. urodziny ks. prof. Heinza Schurmanna. 1 (1998) 73-74

- 80. Zjazd Studiorum Novi Testamenti Societatis (Praga 1995). 2 (1995) 124-126

- O. Sylwester Saller (1985-1976). 5-6 (1976) 312

- VIII Colloqium Biblicum w Wiedniu (1994). 4 (1994) 280-281.

- Panorama współczesnej egzegezy Starego Testamentu (XI Kongres IOSOT w Salamance 1983). 5 (1984) 411-424

— Papirusy z groty 7 Qumran. 2-3 (1973) 93-98

- Paradosis: interpretacja tradycji i hermeneutyka biblijna. 1 (1992) 1-5

- Paweł VI o zadaniach współczesnej egzegezy biblijnej. 4-5 (1974) 265271

- Peregrynacje romantyków do Ziemi Świętej. 5 (1987) 458-460

- Perspektywy apostolstwa biblijnego. 3 (1972) 197-202

- Piąta pieczęć Apokalipsy (6, 9-11). 5 (1984) 429-432

— Pielgrzym do Ziemi Świętej. spec. (1979) 52-53

- Pierwsze przekłady Nowego Testamentu w dziejach i kulturze Europy Środkowej i Północnej. Konferencja naukowa w Zielonej Górze (1998). 4 (1998) 311-313

- Pismo święte w duszpasterstwie. Komentarz do dokumentu „Interpretacja Biblii w Kościele" (IV C 3). 3 (1996) 177-183 
— V Colloqium Biblicum w Wiedniu (1988). 5-6 (1989) 396-397

- 15-lecie istnienia Studium Syndologicznego. 3 (1996) 201-206

- 51 Zjazd Studiorum Novi Testamenti Societatis (Strasburg 1996). 4 (1996) 268-269

— Pogrzeb Jezusa w świetle zwyczajów żydowskich. 2 (1984) 119-127

- Poezja i teologia. Refleksje na temat twórczości poetyckiej kard. Karola Wojtyły. spec. (1979) 42-45

- Pojęcie i rola kerygmatu w pierwotnym Kościele. 2 (1980) 58-68

- Polskie Towarzystwo Teologiczne w Krakowie w hołdzie J. Długoszowi w 500-lecie śmierci. 6 (1980) 354

- „Polszczyzna natchniona”. Sesja na Uniwersytecie Jagiellońskim w czterechsetlecie śmierci ks. Jakuba Wujka TJ. 3 (1997) 213-214

- Prawo w Nowym Testamencie. Sympozjum biblijne w Brixen (1985). 6 (1986) 495-496

— Problemy współczesnej problematyki biblijnej. 1 (1972) 2-12

- Problemy apostolstwa biblijnego. Na marginesie kongresu na Malcie (1978). 5 (1979) 261-265

- Proces Jezusa. Przekaz i historia. Sesja naukowa w Grazu (1987). 3 (1988) 233-234

- Propozycje egzegetyczne Rene Girarda. 2 (1985) 160-169

- Program badań recepcji Vaticanum II w Polsce - Pakiet propozycji. 1 (1986) 21-23

- Reforma studiów na Papieskim Instytucie Biblijnym. 1 (1972) 45-47

- Refleksje o odkupieniu. 1 (1984) 69-78

- Rodzaje literackie i schematy myślenia. O pewnym błędnym przekładzie w DV 12. 1 (1985) 45-46

- Rozmowa z ks. Janem Lambrechtem SJ. 2 (1989) 141-142

- Rozważania w kręgu biblijnym. 2-3 (1979) 164-169

- Rozwój pojęcia sanktuarium. 3 (1984) 209-208

- Sesja qumranologiczna w 25. rocznicę śmierci ks. prof. Aleksego Klawka (Kraków 1994). 3 (1995) 214

— Siedem spojrzeń na płciowość w Biblii. 1 (1997) 28-35

— VII Colloqium Biblicum w Wiedniu (1992). 1 (1994) 52-53

- Słowo Boże skierowane do nas. 1 (1985) 47-49

- Stan współczesnych badań biblijnych nad zmartwychwstaniem Jezusa. 3 (1974) 127-138 
- Struktura nowych czytań mszalnych. 4-5 (1970) 199-211

- Sympozjum o kapłaństwie służebnym w życiu i nauczaniu Jana Pawła II (Kraków, PAT 1996). 2 (1997) 152-155

- Szkice homilii chrzcielnych (I-IV). 1 (1973) 44-47; 3 (1974) 189-193; 1 (1976) 54-57; 4 (1976) 235-237

- VI Colloqium Biblicum w Wiedniu. 1-3 (1991) 63-65

— Śp. ks. Josef Scharbert (1919-1998). 2 (1998) 148-149

— Śp. ks. Francesco Vattoni (1922-1995). 2 (1996) 129-130

- Świadek historii. Homilia w czasie Mszy św. w 500. rocznicę śmierci J. Długosza. 6 (1980) 350-353

- Światowy Dzień Biblii. Ekumeniczne dni biblijne czy niedziela biblijna? 2 (1995) 120-127

- Święci Cyryl i Metody - twórcy Biblii Słowiańskiej. Na kanwie encykliki Jana Pawła II „Slavorum Apostoli”. 2 (1986) 89-96

- Tematy biblijne w przemówieniach Jana Pawła II w Polsce. 1 (1980) 2-9

- Teologia misji w Nowym Testamencie. Sprawozdanie ze zjazdu biblijnego w Würzburgu (kwiecień 1981). 5 (1981) 304-306

— Teologiczny dialog polsko-niemiecki w Moguncji. 6 (1977) 337-338

- Textus receptus współczesnej Biblii polskiej. O trzecim wydaniu Biblii Tysiąclecia. 5 (1981) 274-280

- 32. Zjazd Studiorum Novi Testamenti Societas. 6 (1977) 334-335.

- Uzdrowienie opętanego z Gerary w sztuce starochrześcijańskiej. 4 (1980) 219-221

- Utworzenie światowego stowarzyszenia katolickiego dla apostolstwa biblijnego. 2-3 (1970) 152-155

- Wagrowiec dla ks. Jakuba Wujka. 3 (1977) 214-215

— W czterechsetlecie śmierci ks. Jakuba Wujka (1541-1597). 3 (1997) 173174

- W hołdzie św. Janowi Kantemu w sześćsetlecie urodzin. 1-3 (1991) 1-4

— Wilhelm Thüsing (1921-1998). 3 (1998) 238

— Wokół projektu ekumenicznego thumaczenia Biblii. 1 (1969) 33-40

- W 50. rocznicę wydania encykliki „Divino afflante Spiritu”. 3-4 (1993) $170-176$

— Wspomnienie o ks. Józefie Ricciottim. 2 (1969) 113-114

- Współczesna egzegeza starotestamentalna a duszpasterstwo. 5-6 (1973) 296-307 
- Wykonanie utworów wszystkich G. G. Gorczyckiego. 4 (1984) 338-339

— Zadania rodziców w świetle Pisma świętego. 4 (1977) 214-215

- Zagadka rękopisu Ewangelii św. Marka z groty 7 Qumran. 3 (1995) 182186

- Z działalności Polskiego Towarzystwa Teologicznego w Krakowie w 1971 r. 4-5 (1972) 273

- Z działalności Polskiego Towarzystwa Teologicznego w Krakowie w roku 1984. 3 (1985) 237-242

- Z działalności Polskiego Towarzystwa Teologicznego w Krakowie w roku 1985. 1 (1986) 40-54

- Z działalności Polskiego Towarzystwa Teologicznego w Krakowie w roku 1986. 1 (1987) 79-83

- Z medytacji nad cierpieniem. 2 (1984) 159-160

- Znaczenie odkrycia ossuarium człowieka ukrzyżowanego dla egzegezy Męki Pańskiej. 4-5 (1972) 229-234

- Znaki pokuty w Piśmie świętym - Rozważania semiotyczne. 2-3 (1976) 172-174

— Żydzi i chrześcijanie w dialogu. Kolokwium w Krakowie i Tyńcu 1988. 3 (1988) 231-232

CHMIELARSKI Wacław ks., Godzina biblijna w parafii św. Tomasza Ap. w Sosnowcu. 5 (1962) 310-314

- Tygodnie i wystawy biblijne - jako formy apostolatu biblijnego. 2 (1965) 108-111; 4-5 (1966) 308-315

CHMIELOWSKA Bogusława CR, Idea życia pozagrobowego w księdze Mądrości. 46 (1951) 402-410

CHMURA Tomasz ks., Kult liturgiczny św. Floriana w Krakowie od połowy XIV wieku. 4 (1984) 318-328

CHODZIDŁO T[eofil] SVD, 85-lecie ks. Wilhelma Schmidta SVD. 1 (1953) 198-200

CHOLEWIŃSKI Alfred SJ, „Postępujmy w światłości Jahwe” (Iz 2, 5). Proroctwo o prawdziwym rozbrojeniu (Iz 2, 1-5). 5-6 (1989) 321-328

- Przymierze w Moabie. 5 (1984) 380-386

— Wigilia biblijna. 3 (1967) 172-182

CHORZĘPA Michał CM, Aktualny stan procesów beatyfikacyjnych Polaków w Kurii Rzymskiej. 2 (1987) 144-153

CHROMIK Tadeusz SJ, Jak wprowadzić dziecko w wieku przedszkolnym w uczestnictwo we Mszy św. 4-5 (1968) 258-265 
CHROMIK Tadeusz SJ, KUBIK Władysław SJ, Liturgia a katecheza. 3 (1967) 154160

CHROSTOWSKI Waldemar ks., Zbiór pieczęci z czasów proroka Jeremiasza. 3 (1987) 191-201

— „Ziemia mlekiem i miodem płynąca”. Medytacja nad geografią historyczną Palestyny. 4-6 (1991) 131-138

— Żydowsko-chrześcijańskie seminarium w Chicago. 5-6 (1989) 398-402

CICHY Stefan ks., Język łaciński w odnowionej liturgii. 2 (1978) 83-88

- Niedziela w rodzinie. 1 (1981) 44-51

- Odnowa liturgiczna Soboru Watykańskiego II. Rzeczy dokonane - Idee przewodnie - Perspektywy. 1 (1986) 4-15

- Odnowa liturgii a ekumenizm w Polsce. 4-5 (1985) 372-381

- Rozpoczęcie świętowania niedzieli w sobotę. 1-2 (1990) 36-42

- Sprawozdanie z III sympozjum „Vetera et nova”. 4 (1976) 228-234

- Sprawozdanie z sympozjum „nova et vetera” (IV) na temat „Misterium liturgii - czym jest"? 3 (1988) 240-242

- Uczył wdzięczności — zaskarbił sobie wdzięczność. 6 (1983) 512-513

— Z działalności Polskiego Towarzystwa Teologicznego w Krakowie w roku 1987.3 (1988) 234-240

CIESIELSKI Augustyn OCist., Ostatnie namaszczenie - Sakrament umierających czy chorych? 2-3 (1955) 115-131

CIEŚLIK Piotr ks., Kerygmat o Jezusie z Nazaretu w kazaniach misyjnych Dziejów Apostolskich. 2 (1981) 113-119

CINAL Stanisław, Ks. prof. A. Klawek i ks. prof. J. Archutowski jako religioznawcy. 1 (1995) 55-58

de CLERK Paul ks., Wpływ konstytucji o liturgii na współczesne duszpasterstwo. 1-2 (1990) 8-20

CSESZNAK Karol ks., Liturgia a duszpasterstwo. 4 (1948) 217-229

CZAJKOWSKI Michał ks., Dni biblijne w Lowanium. 6 (1961) 333-336

- Chrzest zanurza w misterium paschalne Chrystusa. 6 (1971) 313-319

- Na tropach tradycji eschatologicznej i mesjańskiej u Ben-Syracha. 2-3 (1963) 87-98

- 100 lat biblistyki w École Biblique. 2 (1994) 111-120

— Śp. ks. prof. H. Zimmermann (1915-1980). 6 (1980) 358-359

CZEKAŃSKA Maria, Lapides pretiosi omnes muri tui. 4 (1949) 246-252 
CZERNIAK Jan ks., Kult Najświętszego Serca Jezusowego w liturgii mszalnej. 4 (1949) 271-279

- Starania o zatwierdzenie przez Kościół Mszy świętej o Sercu Jezusowym. 3 (1949) 172-185

CZERSKI Janusz ks., Nowotestamentalna terminologia miłosierdzia. 1 (1987) 19-26

CZERWIK Stanisław ks., Liturgia szkołą formacji kapłańskiej. 4-6 (1991) 104-117

- Odnowa liturgii w świetle konstytucji i instrukcji liturgicznej. 3 (1965) $162-174$

- Odnowiona liturgia sakramentu pokuty w świetle „Ordo Paenitentiae”. 23 (1976) 134-147

- Prezbiter przewodniczący sprawowaniu liturgii - sakramentem Chrystusa w Duchu Świętym i w Kościele. 3 (1989) 179-187

- Refleksja teologiczna nad liturgia sakramentu bierzmowania. 1-2 (1975) $32-44$

- Teologia liturgii w ujęciu konstytucji „Sacrosanctum Concilium” i w całokształcie dzieła Soboru Watykańskiego II. 2 (1988) 155-168

CZERWIŃSKI Zbigniew ks., Wspomnienie o ks. Wojciechu. 5 (1986) 459-460

CZOSNOWSKA-ŁUBIŃSKA Helena, Od polskich „Godzinek” do biblijnego myślenia. 4 (1957) 299-311

D. ks., Śp. matka Innocenta przełożona Domu Polskiego w Jerozolimie. 4 (1949) 296299

DADAK Stanisław ks., Kalendarium życia papieża Jana Pawła II. spec. (1979) 5-8

- Wspomnienie o ks. Michale Kordelu. 6 (1972) 354-356

DAJCZAK Józef ks., Osobowość pedagogiczna Chrystusa. 3-4 (1950) 173-187

DANIEL Stanisław OFM, Nowe odkrycia na Górze Oliwnej. 4 (1957) 312-314

— Znaczenie wyrażenia „palec Boży” w Piśmie świętym. 4 (1957) 247-260

DANIELSKI Wojciech ks., Bierzmowanie w koncelebrze (propozycje pastoralne). 1-2 (1975) 82-85

- Czytania biblijne o bierzmowaniu (propozycje doboru i wprowadzeń). 1-2 (1975) 79-82

- Czytania w Mszy za zmarłych. 1-2 (1974) 77-88

- IX sympozjum liturgiczno-pastoralne na temat „Błogosławieństwa”. 4 (1979) 246-248

- Dyrektorium duszpasterskie Episkopatu Polski o chrzcie dzieci z 1965 r. 2 (1972) 138-140

- XII sympozjum naukowe wykładowców liturgiki w Polsce — Kraków, 45 września 1974 r. 2-3 (1976) 159-161 
- XI seminarium naukowe wykładowców liturgiki w Polsce - Poznań, 5-6 września 1973 r. 5-6 (1976) 157-159

- Pożegnanie śp. ks. profesora Wacława Schenka - Bytom, 2 listopada 1982 r. 6 (1983) 519-520

- VII sympozjum liturgiczno-pastoralne nt. „Dyrektorium o mszach z udziałem dzieci”. 2-3 (1977) 154-157

- Sprawozdanie z X seminarium naukowego wykładowców liturgiki w Polsce — w Krakowie 4-5 września 1972 r. 1-2 (1975) 72-78

- Sprawozdanie z X sympozjum liturgiczno-pastoralnego na temat „Dzień Pański-Niedziela w duszpasterstwie". 1 (1981) 73-77

- Wybrane fragmenty z oficjum za zmarłych. 1-2 (1975) 95-102

DANIELSKI Wojciech ks., PAPIERNIK Stanisław ks., Sprawozdanie z sympozjum „Obrzędy chrztu dzieci”. 2 (1972) 140-144

DĄBEK Tomasz Maria OSB, Aniołowie opiekunami Kościoła w Apokalipsie św. Jana. 4 (1984) 305-313

— „Dla mnie żyć — to Chrystus” (Flp 1, 21) — Pawłowa odpowiedź na odwieczne pytanie o sens ludzkiego życia. 2 (1986) 121-126

- Duch, dusza i ciało w 1 Tes 5, 23.4 (1987) 288-296

- Dziecko w Biblii. 5-6 (1989) 359-362

— Eucharystia jako duchowy pokarm w 1 Kor 10, 3. 6 (1988) 465-470

- Jak odnowić zapał do Biblii? Refleksje dla głosicieli Słowa Bożego. 4 (1998) 276-284

- Muzyka liturgiczna w Starym i Nowym Przymierzu. 3 (1987) 252-257

- Post w pierwotnym Kościele na podstawie Nowego Testamentu. 3-4 (1993) 161-169

- Post w życiu Jezusa Chrystusa. 2 (1989) 125-131

- Przygotowanie idei Eucharystii jako duchowego pokarmu w Starym Testamencie. 4 (1988) 313-319

- Refleksja na temat osobowości i zadań duszpasterstwa na podstawie Pisma świętego. 4 (1989) 290-294

DĄBROWSKI Bogusław, Pieczęć królewskiego sługi. 6 (1988) 528-532

DĄBROWSKI Eugeniusz ks., Odkrycia nad Morzem Martwym po dziesięciu latach (1947-1957). 6 (1957) 359-381

- Pismo święte a chrześcijaństwo współczesne. 2-3 (1970) 128-133

le DEAUT Roger CSSP, Septuaginta — Biblia zapoznana. 6 (1964) 454 -470

DEKIEL Waldemar ks., Gesty i funkcje liturgiczne dzieci. 2-3 (1977) 149-151 
DEPCZYŃSKI Wincenty ks., Z dziejów ruchu liturgicznego w Polsce. 4 (1949) 299302

DEPTUŁA-JABŁOŃSKA Ewa, Ksiądz Wojtek. 5 (1986) 463-465

DERDAU Albin ks., Kolor czarny, fioletowy czy też inny? 4-5 (1968) 307-311

- Pokrzepiająca Msza święta. 4-5 (1969) 300-302

DŁUGOSZ Antoni ks., Rodzaje literackie Sdz 6-8. 2-3 (1979) 80-90

_ Tekstualne trudności opowiadania o Gedeonie. 5 (1980) 263-269

DŁUGOSZ Teofil ks., Gloria maryjne. 1 (1951) 127-128

- Obraz Matki Bożej Łaskawej w katedrze lwowskiej. 4-6 (1956) 203-205

- 500-lecie urodzin św. Kazimierza. 2 (1959) 175-183

- Sprawy liturgiczne w XVI wieku w diecezji krakowskiej. 3 (1951) 297318

- Życie liturgiczne w Krakowie za czasów królowej Jadwigi. 5 (1960) 461474

DONARSKI Zbigniew ks., Wpływ środowiska rodzinnego na osobowość ks. prof. Wacława Schenka. 6 (1983) 483-486

DOWSILAS Józef ks., Wspomnienia kapelana. spec. (1979) 46-51

DRĄŻEK Czesław SJ, Bractwo Serca Jezusowego w dawnej Polsce. 3 (1981) 173-182 DREJA Antoni ks., Śp. ks. Konrad Marklowski (1912-1990). 1 (1993) 40-42

DROZD Jan SDS, Czwarty Ewangelista w świetle legendy i sztuki. 4-6 (1951) 417431

- Ostatnia Wieczerza w świetle ostatnich dyskusji. 5-6 (1952) 436-445

DRZYMAŁA Kazimierz SJ, Grób św. Piotra Apostola w Rzymie. 4 (1986) 353-362

- Katakumby rzymskie. 1 (1985) 53-74

- Ks. Jakub Wujek z Wagrowca (1541-1597). 1-2 (1950) 23-63

- Ks. Jakub Wujek z Wagrowca obrońca chłopów polskich. 4 (1959) 363372

- Ks. Marcin Śmiglecki obrońca prymatu św. Piotra i jego następców. 4 (1964) 215-230

- Ks. Walenty Prokulski SJ wybitny egzegeta Nowego Testamentu (18881968). 2-3 (1969) 94-102

DURAK Adam SDB, Kolekty dni powszednich Wielkiego Postu według mszału Pawła VI. 2 (1995) 100-107

- Teksty euchologijne jako źródło teologiczne (euchologia liturgiczna). 1 (1994) 32-37 
- Zbawcza pedagogia nawrócenia w celebracji naboźeństw pokutnych. 3 (1996) 184-193

DYBOWSKI Mieczysław ks. Odpowiedź ks. prof. Florkowskiemu na jego krytykę 3 sakramentów umieszczoną w RBL IX, 1956. 4 (1957) 331-336

DYDUCH Jan ks., Polskie Towarzystwo Teologiczne w Krakowie. 5 (1987) 437-445

- Posługa lektora i akolity w świetle obowiązujących przepisów kościelnych. 2 (1987) 133-141

- Udział świeckich w kulcie liturgicznym w świetle Kodeksu Prawa Kanonicznego. 1 (1995) 16-28

DYKIEL Zbigniew MSF, Znaczenie eulogein i wyrażeń pokrewnych w Septuagincie. 3-6 (1990) 131-135

DYLUS Franciszek ks., Antropologia encykliki Jana Pawła II „Redemptor hominis”. 6 (1979) 322-328

- Eucharystyczny charakter tajemnicy Kościoła na podstawie konstytucji „Lumen gentium”. 4 (1987) 323-331

- Niektóre aspekty eschatologii Kościoła w świetle „Lumen gentium”. 5-6 (1989) 349-358

DYRDA Jan ks., Religijne pośrednictwo patriarchów Izraela. 3-4 (1993) 157-161

Dyskusja naukowa nad „Archeologią Palestyny” na UJ. 6 (1974) 343

DZIUBA Andrzej ks., Biblijna idea oddania się Bogu w wierze. 6 (1981) 354-361

- Komentarz Jana Azora SJ (1536-1603) do Pieśni nad pieśniami. 4 (1989) 269-275

— „Kto uwierzy i przyjmie chrzest” (Mk 16, 16). Wiara a sakramenty. 6 (1984) 493-500

- Pismo święte w twórczości teologiczno-moralnej Mikołaja z Mościsk (1559-1632). 5 (1983) 400-406

DZIWOSZ Bogdan ks., Kultyczny charakter sakramentu pokuty. 2-3 (1976) 148-156

ECKMANN Augustyn ks., Psalm 8 w świetle badań filologiczno-egzegetycznych. 4 (1981) 194-203

EJSMONT Marian MS, Czterdziesta rocznica śmierci ks. prof. Władysława Szczepańskiego TJ. 1 (1967) 48-54

Encyklika „Divino afflante Spiritu” o charakterze studiów biblijnych. 3 (1948) 55-57

ENHOLC-NARZYMSKA Barbara, Ekumeniczny Tydzień Biblijny. 2 (1995) 127-137

- Sprawozdanie ze Święta Biblii 1996. 1 (1997) 66-73

ERHLICH Emilia OSU, Biblia o kobiecie. 6 (1975) 245-252

- Określenie Boga w I księdze Psalmów. 1 (1997) 37-54.

— Stan badań nad Ps. 29. 4-5 (1974) 198- 204 
FAMUŁKA Andrzej ks. Kim był dla mnie ksiądz Profesor? 6 (1983) 515-517

FEDERKIEWICZ Piotr ks., Agonia Chrystusa Pana w Ogrójcu (Uwagi egzegetyczne do Łk 22, 43 n). 2 (1960) 119-126

FEDOROWICZ Aleksander ks., Nasza Msza św. 3 (1959) 283-288

FEDOROWICZ Szymon ks., Ewangelizacyjny charakter obrzędów przedchrzcielnych. 2 (1997) 133-143

- Ewangelizacyjny wymiar obrzędu wybrania czyli wpisania imienia. 3 (1998) 186-196

- Przekaz wiary a włożenie rąk w obrzędach katechumenalnych. 1 (1998) $38-47$

FEICHT Hieronim CM, Polska twórczość gregoriańska. 3 (1967) 169-171

FENDRYCH Władysław, Refleksje z okazji wystawienia Całunu Turyńskiego (18.0414.06.1998). 3 (1998) 215-217

FIC Atanazy OP, Epifania Jezusa Chrystusa. 1 (1948) 10-18

FIGLEWICZ Kazimierz ks., Missa ad libitum. 2 (1949) 142-143

- Msza wotywna do Pana Jezusa Najwyższego i Odwiecznego Kapłana. 1 (1948) 47-48

— Z aktów Stolicy Świętej. 4 (1948) 253-254

FIGURA Adam, Zabudowa Akropolu w Jerozolimie od czasów panowania Dawida ok. 1000 roku przed Chr. (do 586 r. przed Chr.). 6 (1988) 487-496

FILIPIAK Marian ks., Egzaminy kwalifikacyjne do stopni biblijnych w Katolickim Uniwersytecie Lubelskim w 1966/67. 4 (1971) 224-225

- Kohelet a księga Rodzaju. 2-3 (1973) 78-85

- Krytyka mądrości w księdze Koheleta. 4-5 (1975) 159-168

- Powołanie Ludu Bożego. 5-6 (1976) 304-310

- Przymierze w Piśmie świętym. 3 (1972) 145-155

- Społeczno-prawne znaczenie złorzeczeń w Piśmie świętym. 1-2 (1968) 32-39

FISCHER Balthasar ks., Stan reform liturgicznych w Niemczech Zachodnich. 4 (1976) 207-213

FLIS Jan ks., Demony według NT — Mit czy rzeczywistość. 1 (1987) 40-49

- Jak opracować konkordancję biblijną? 1 (1989) 54-57

— Triduum św. Łukasza w parafii lubelskiej. 3 (1987) 234-236

- Tryptyk biblijno-pasyjny w parafii w Giełczwi. 2 (1989) 146-147

FLORKOWSKI Eugeniusz ks., Istota Mszy św. według encykliki liturgicznej Piusa XII „Mediator Dei”. 2 (1948) 72-78 
- Liturgia a dogmat. 3 (1952) 240-246

- Rzut oka na literaturę mariologiczną okresu powojennego. 1 (1951) 129134

- Święto Wniebowzięcia Najświętszej Maryi Panny a sprawa dogmatu mariologicznego. 4 (1948) 229-235

— Wyjaśnienie ks. M. Dybowskiemu. 4 (1957) 337-340

FORTUNA Mariola, Hebrajska ewangelia św. Mateusza ze średniowiecznego traktatu żydowskiego. 4 (1989) 241-249

FRANKOWSKI Janusz ks., Biblia Tysiąclecia — jej wartości i znaczenie. 2-3 (1970) 76-87

- Księgi Sybillińskie. 5-6 (1973) 261-270

- List Arysteasza czyli legenda o powstaniu Septuaginty. 1 (1972) 12-22

- Trzecia księga Ezdrasza. 1 (1973) 4-7

FULAR MARIAN, Refleksje o liturgii posoborowej w Polsce. 6 (1985) 458-463

GACEK Stanisław ks., Autor księgi Jozuego. 1 (1984) 35-41

- Data napisania księgi Jozuego. 6 (1987) 476-480

GAJDA Janusz ks., Msza święta w kulturze Zairu. 2 (1998) 122-134

GAJDA Piotr ks., Miejsce chrztu w nowej koncepcji wnętrza kościelnego. 2 (1972) 126-134

GALAS Michał, Duchowość Żydów polskich w pracach Gershoma Scholema. 3 (1995) 186-191

- Metoda aforyzmów G. Scholema czyli stosunku współczesnej filozofii do kabały. 2 (1989) 139-141

- The 5th Congress of European Association for Jewish Studies. 4 (1994) 281-282

GAWEŁ Józef SCJ, Serce Jezusa w nowych tekstach liturgicznych. 2-3 (1979) 131137

GĄDECKI Stanisław bp, Historiografia w 2. księdze Machabejskiej. 1 (1994) 1-7

GĄSIOROWSKI Konrad ks., Dwa Psałterze ks. Wujka. 3 (1959) 246-259

- Przekład Psałterza w Biblii Leopolity (w czterechsetlecie wydania Biblii). 5 (1961) 189-195

GLEMMA Tadeusz ks., Śluby Jana Kazimierza. 4-6 (1956) 187-203

GLIŃSKI Efrem OP, Nowe przekłady Pisma świętego - Nowy Delegat Apostolski Palestyny. 3 (1948) 185-186

- O. Voste OP. 2 (1949) 140-141 
- Wyjaśnienie Komisji Biblijnej w sprawie nowego przekładu psałterza. 2 (1948) 101-102

- Wykopaliska w Palestynie. 2 (1948) 102-104

— Z historii Grobu Świętego. 2 (1948) 64-71

— Ze świata biblijnego. 1 (1948) 38-47

Głosy z dyskusji (oprac. ks. Marian Zielniok). 3 (1984) 230-231

Głosy w dyskusji na XII Kongresie Biblistów we Wrocławiu. 4-5 (1975) 239-243

GŁOWA Władysław ks., Czym utrwalił się w mej pamięci sp. ks. prof. Wacław Schenk? 6 (1983) 507-512

- Odnowa liturgii w seminariach duchownych. 4-5 (1985) 331-338

- Piętnaście lat odnowy liturgicznej w diecezjach polskich (1964-1979). 3 (1983) 222-233

- Powołany na sprawowanie liturgii niebieskiej. 5 (1986) $452-454$

— Tereny zagrożone odnowionego „Ordo Missae”. 1 (1981) 52-60

GNILKA Joachim ks., Jesu ipssisima mors. 1 (1988) 2-13

GNUTEK Wawrzyniec ks., Cztery ewangelie w świetle konstytucji soborowej „Dei Verbum". 1 (1967) 13-24

— Jego to ustanowił czy wystawił? (Rz 3, 25). 4-5 (1968) 220-226

— Konstytucja „Dei Verbum” a cztery ewangelie. 3 (1967) 124-135

- Najstarsze źródła pozabiblijne o Chrystusie w świetle badań Józefa Klausnera. 1 (1962) 1-9

- Paweł z Tarsu — apostoł Jezusa Chrystusa i pisarz natchniony. 3 (1965) 142-151

— Pieśń świętego Pawła o Miłości (1 Kor 12, 31-14, 1). 2 (1960) 105-117

— Przypowieści Chrystusowe. 4 (1950) 333-334

GODLEWSKI Michał abp, Pierwszy Kościół w Atenach. 1 (1953) 147-154

GOŁĘBIEWSKI Marian ks., Idea „nowego wyjścia” u DeuteroIzajasza (na podstawie analizy Iz 55, 12-13). 4 (1994) 324-242

- Powiązania literackie i znaczenie teologiczne trzech perykop w ewangelii Janowej (3, 1-13; 4, 1-42; 4, 46-54). 4-5 (1975) 182-199

— Wspomnienie o ks. Franciszku Jóźwiaku (1931-1988). 1 (1989) 69-70

GÓRSKI Jan ks., Ewangelizacja. 4-6 (1991) 138-141

- Katechumenat w krajach misyjnych. 5-6 (1989) 138-141

GÓRSKI Tytus, Agnostos Theos. 1 (1953) 154-159

— Uniwersytet katolicki św. Józefa w Bejrucie. 3 (1949) 216-218

GRABIANKA Stanisław, Drogi Jezusowe. 3-4 (1961) 109-114 
- Syn marnotrawny (Łk 15, 11-31). 2 (1964) 109-112

— W bazylice Grobu Świętego. 1 (1949) 34-39

GRABOWSKI Tadeusz, Założenie metafory małżeńskiej według księgi Ozeasza. 3 (1987) 236-244

GRANAT Wincenty ks., Msza św. jako ofiara Kościoła. 6 (1949) 411-440

GRENIUK Franciszek ks., Lokalizacja Liturgii Słowa. 3 (1966) 172-181

GROBLICKI Julian ks., Duszpasterskie przygotowanie obchodu Wielkiego Tygodnia i Wigilii Paschalnej. 2 (1960) 139-151

- O co właściwie chodzi? 3-4 (1960) 347-358

GROCHOCKI Józef ks., Mszał łacińsko-polski sprzed stu lat (Przyczynek do historii ruchu liturgicznego w Polsce). 4 (1952) 359-364

— Z dziejów officium divinum. 1 (1952) 53-68

GRONKOWSKI Witold ks., In Spiritu et veritate (J 4, 13). 2 (1954) 194-204

- „Przyjacielu, jakże tu wszedłeś nie mając szaty godowej” (Mt 22, 13). 1 (1959) 24-28

GRYGIEL Stanisław, Znak błogosławiony i jego negacja. 4 (1979) 182-192

GRYGLEWICZ Feliks ks., Badania ks. prof. A. Klawka nad Nowym Testamentem. 6 (1970) 276-279

- Bogactwo i trudności - metafory o Królestwie Bożym w nauczaniu Chrystusa Pana. 1 (1963) 42-48

- Inspiracje biblijne w polskiej literaturze (szkic zagadnienia). 5 (1984) 373-379

- Interpretacja Apokalipsy św. Jana. 6 (1965) 346-357

- Janowa postać Boga. 1 (1977) 65-67

- Janowy Kościół a teologia czwartej Ewangelii 1 (1979) 34-46

- Jaki pragnę mieć Kościół? 6 (1949) 448-451

- Litostrotos. 1 (1960) 39-46

- Mapa Madaby. 3-4 (1961) 125-129

- Opis końca świata u św. Piotra i w Qumran. 3 (1959) 270-282

- O typach przekładu Pisma świętego. 5-6 (1948) 351-352

- Praprzekład Ewangelii ks. Jakuba Wujka. 1 (1954) 16-41

- Pierwszy po ks. Wujku przekład Nowego Testamentu. 1-2 (1959) 92-97

- Pierwotna liturgia chrztu św. jako źródło Pierwszego listu św. Piotra. 3 (1958) 206-210

- Pismo święte w duszpasterstwie. 2 (1948) 84-89

- Pismo święte w liturgii. 4 (1952) 328-338 
— Pochodzenie „Reguły wojny” z Qumran i data jej kompozycji. 1 (1962) 918

- Problem miłości w Nowym Testamencie. 4-5 (1974) 257-265

- Prolog Ewangelii i Pierwszego listu św. Jana. 1 (1958) 15-22

- Rozwój teologii Listu św. Judy i Drugiego listu św. Piotra. 5 (1980) 247258

- Ryby i rybacy Tyberiadzkiego Jeziora. 6 (1949) 382-405

- Społeczny charakter Modlitwy Pańskiej. 3-4 (1950) 207-219

- Zagadkowy fragment czwartej Ewangelii (J 4, 31-38). 4 (1981) 203-214

GRYGOTOWICZ Józef ks., Zastosowanie środków audiowizualnych do udziału dzieci w Mszach św. 2-3 (1977) 152-154

GRYZIEC Piotr OFMConv, Łaska spotkania chrześcijan według św. Pawła. 1 (1995) $17-27$

— Specyfika paraklezy w listach św. Pawła. 2 (1996) 85-90

- „Z uczynków prawa nikt nie może dostapić usprawiedliwienia” (Rz 3, 20). 1 (1997) 16-22

GRZELAK Andrzej ks., Eucharystia w parafii. Sympozjum liturgiczno-katechetyczne w Katolickim Uniwersytecie Lubelskim. 4 (1987) 331-335

GRZEŚKOWIAK Jerzy ks., Niektóre problemy teologiczne znaku liturgicznego. 4 (1979) 192-205

GRZYBEK Stanisław ks., Biblia a liturgia. 2-3 (1971) 84-95

- Biblia prawda czy legenda? 6 (1961) 312-322

- Biblijne inspiracje encykliki Jana Pawła II „Redemptoris Mater”. 4 (1989) 278-283

— Bóg Izajasza w świetle jego wizji (Iz 6, 1-13). 3 (1997) 175-187

— „Czas, abym odszedł”. 6 (1970) 302-305

- Czy Chrystus miał braci? 3 (1958) 231-238

- Czy pierwsze przykazanie pozwala czcić obrazy? 1 (1958) 50-54

- IV Kongres Mariologiczny i Maryjny w Olsztynie i Gietrzwałdzie. 4-5 (1977) 220-221

- Dni Biblijne w Louvain. 6 (1974) 340-342

- XXIV Dni Biblijne w Louvain. 5-6 (1973) 321-324

- Dni Studium Mariologicznego na Jasnej Górze. 5 (1960) 481-483

- Drugie naukowe seminarium biblijne. 5 (1960) 484-486

- Działalność pisarska kard. Karola Wojtyły w Polskim Towarzystwie Teologicznym w Krakowie. spec. (1979) 36-41 
- Elementy konstytutywne biblijnej radości. 5 (1979) 250-260

- Egzystencjalne wartości Starego Testamentu. 5-6 (1976) 241-254

- Formy apostolatu Pismem świętym. 1 (1986) 55-69

- Finis legis Christus (Rz 10, 4). 5 (1961) 181-189

- Homilia na Boże Narodzenie. 4-5 (1971) 241-245

- Homilia wygłoszona na pogrzebie ks. prof. Stanisława Łacha w dniu 12 czerwca 1983 r. 1 (1984) 2-5

- Homilie adwentowe. Rok C. 5-6 (1976) 317-324

- Homilie na niedziele i święta okresu Bożego Narodzenia. Rok B. 6 (1981) 401-416

- Homilie niedzielne i świąteczne. Rok C. 3 (1983) 243-277; 4 (1983) 353372; 5 (1983) 434-466

- Homilie na niedziele Adwentu i okresu Bożego Narodzenia. Rok B. 5 (1981) 321-336

- Homilie na okres Wielkanocy. 2 (1983) 177-190

- Homilie wielkotygodniowe. Rok C. 1 (1983) 89-98

- J. E. ks. biskup dr Julian Groblicki. 5 (1960) 475-476

- Kazanie wygłoszone na pogrzebie ks. prof. Władysława Smereki. 2 (1984) 99-102

- Kerygmatyczna wartość pochwały Jozuego na podstawie Syr 46, 1-8. 2-3 (1979) 73-79

- Kerygmatyczne wartości encykliki Jana Pawła II „Redemptor hominis”. 6 (1979) 290-297

- Kerygmatyczne wartości Pisma świętego. 1 (1978) 1-8

- Kerygmatyczne wartości Pisma świętego w świetle ewangelizacji współczesnego świata. 1 (1995) 27-33

- Komentarz do Pisma świętego Nowego Testamentu. 6 (1959) 591-592

- Książki nadesłane do Redakcji. 3-4 (1960) 382-384

- Księga Tobiasza - Wstęp — przekład — komentarz. 1-2 (1961) 1-22

- Ks. prof. Aleksy Klawek - założyciel i pierwszy naczelny redaktor „Ruchu Biblijnego i Liturgicznego". 4 (1980) 182-187

— Kto jest moim bliźnim? 4 (1964) 311-315

- Ludzkie drogi naszego życia w kontekście Psalmu 1. 1 (1998) 1-7

- Magnificat anima Dominum. 4 (1964) 238-243

- Manuskrypty z Qumran a chrześcijaństwo. 2 (1960) 81-103 
- Mariologia Jana Pawla II w świetle jego pielgrzymki do Polski. 1 (1980) 10-15

- Mesjańskie królestwo pokoju na Syjonie (na podstawie Iz 2, 2-5). 4-6 (1956) 227-243

- Metodologia teologii biblijnej. 2 (1985) 89-99

- Misyjny charakter Kościoła. Aspekt biblijno-teologiczny. 6 (1978) 282290

- Modlitwa Chrystusa w Getsemani (godzina biblijna). 1 (1964) 41-47

- Naukowe seminarium biblijne. 6 (1959) 589-590

- Nowa instrukcja o muzyce w liturgiii świętej. 3 (1967) 185-186

- Nowa redakcja Collectanea Theologica. 4-5 (1969) 296-298

- Obchody ku czci ks. Jakuba Wujka. 1-2 (1950) 149-150

- Objawienie a człowiek. 4 (1952) 343-351

- Obraz Boga w Starym Testamencie. 1 (1977) 2-18

- Odnalezienie nowych rękopisów biblijnych. 1 (1949) 66-67

- Okres „Sędziów” w dziejach Izraela. 1 (1954) 4-16

— Ostatnia droga śp. ks. prof. Piotra Stacha. 5 (1961) 264-266

- Pierwszy narodowy Kongres Teologii Soboru Watykańskiego Drugiego. 4-5 (1966) 297-308

— Pismo św. w Kościele. 1 (1962) 50-52

— Pismo św. w życiu katolika. 1 (1952) 74-81

— Pius XII a Biblia. 6 (1958) 466-475

- Pochyleni nad stronicami Biblii. 2 (1984) 150-159

— „Pod wieczór życia sądzeni będziemy z miłości” (homilia). 1 (1979) 6163

- Poglądy św. Pawła na pracę fizyczną. 5-6 (1952) 391-399

- Polscy bibliści obradują na KUL-u. 4-5 (1969) 298-300

- Podziękowanie za przyznane mi odznaczenie. 1 (1998) 69

- Post w Starym Testamencie. 2 (1949) 94-103

- Powstanie i rozwój litanii do Najświętszej Maryi Panny. 1 (1951) 97-108

- Problematyka życia rodzinnego w księdze Tobiasza. 2 (1989) 119-124

- Problem autorstwa Pięcioksięgu w ujęciu egzegetów katolickich. 5 (1960) 385-406

- Problem pochodzenia człowieka w świetle egzegezy biblijnej. 2 (1959) 113-125 
- Psałterz - księga naszych ludzkich zobowiązań. 1 (1983) 1-9

- Rekonstrukcja tekstu pieśni Debory (Sdz 5). 1 (1955) 1-15

- Religijny czy świecki charakter księgi Estery. 1 (1962) 18-28

— Rok jubileuszowy w Piśmie świętym. 3 (1974) 109-121

— Rodzaj literacki księgi Tobiasza. 1 (1963) 36-42

- Sprawiedliwość Boga w nauczaniu proroków Starego Testamentu. 5 (1959) 433-451

- Starotestamentowe ofiary w ludziach a ślub Jeftego ( $\mathrm{Sdz} 11,30-40)$. 1-3 (1956) 9-23

- Szkice homilii na Adwent. 4 (1973) 224-237

- Szkice homilii na niedziele Adwentu i okresu Bożego Narodzenia roku A. 5 (1977) 274-280

- Szkice homilii na niedziele i święta roku A (Nowy Rok - III niedziela Wielkiego Postu). 6 (1977) 343-354

- Szkice homilii niedzielnych i świątecznych roku A (IV niedziela Wielkiego Postu do VI niedzieli paschalnej). 1 (1978) 41-54

- Szkice homilii niedzielnych i świątecznych roku A (od 4 V do 29 VI). 2 (1978) 101-113

- Szkice homilii niedzielnych i świątecznych roku A. (2 VII do 1 X) 3 (1978) 158-170

- Szkice homilii niedzielnych i świątecznych roku A (od 8 X do $26 \mathrm{XI}$ ). 4 (1978) 217-224

— Śp. ks. prof. Aleksy Klawek (1890-1969). 6 (1970) 259-266

— Śp. ks. Walenty Prokulski SJ (1888-1968). 4-5 (1968) 297-299

- Święto Objawienia Pańskiego (homilia). 4-5 (1971) 252-255

— Teologia księgi Estery. 4 (1962) 203-214

— Teologiczne Dni Studyjne w Mödling. 4 (1977) 218-219

- Trzecie seminarium biblijne. 5 (1961) 267-269

- Ubi Petrus ibi Ecclesia. 5-6 (1963) 229-235

- Uroczystość Niepokalanego Poczęcia (homilia). 4-5 (1971) 237-245

— Uroczystość Świętej Bożej Rodzicielki (homilia). 4-5 (1971) 248-252

— Uroczystość św. Józefa (homilia). 1 (1972) 61-65

— Uroczystość Świętej Rodziny (homilia). 4-5 (1971) 245-248

- Wpływ lektury Pisma świętego na duchową formację chrześcijanina. 3 (1994) 197-204

- Wprowadzenie w Dzieje Apostolskie (Dz 1, 1-2). 1 (1966) 51-56 
- Wspomnienie o ks. Józefie Archutowskim. 3-4 (1950) 164-173

- Wykopaliska w Hacor. 1-3 (1956) 166-170

- Zarys historii zbawienia. 4-5 (1967) 209-218

- Zebranie Polskiego Towarzystwa Teologicznego. 1 (1963) 36-42

— Złote jubileusze kapłańskie. 3 (1962) 133-145

- Znaczenie nowych manuskryptów biblijnych. 6 (1949) 405-411

— Znaczenie pielgrzymki Pawła VI. 6 (1964) 340-345

- Zwiastowanie NMP (homilia). 1 (1972) 65-68

GRZYBOWSKI Michał Marian ks., Śp. ks. Konrad Gąsiorowski (1914-1982). 4 (1983) 336-341

GRZYMSKA Urszula CR, Radosny aspekt paruzji w listach św. Pawła do Tesaloniczan. 4 (1994) 247-255

GUSTAW Romuald OFM., Św. Antoni z Padwy — doktor ewangeliczny. 3 (1948) 152-167

GUZIAKIEWICZ Edward, Paruzja Chrystusa w nowych „Obrzędach pogrzebu”. 3 (1980) 168-173

GY Pierre Marie OP, Odnowa liturgiczna we Francji. 2 (1988) 168-177

HAŁAS Stanisław SCJ, Chciwość pieniędzy korzeniem wszelkiego zła według $1 \mathrm{Tm}$ 6, 9-10. 4 (1987) 297-305

- Oryginalność koncepcji odrodzenia według Pierwszego listu św. Piotra. 3 (1986) 243-249

— XXXIII sympozjum biblistów polskich w Szczecinie (1995). 1 (1996) 5354

- Zmartwychwstanie Chrystusa przyczyną nadrzędną naszego odrodzenia wg 1 P 1, 3-23. 5 (1984) 393-400

HAŁAS Stanisław SCJ, SKOCZYLAS Henryk CSMA, 30. sympozjum biblistów polskich w Łomży (1992). 1 (1993) 32-34

HANELT Tadeusz ks., Pojęcie bliźniego w starotestamentalnym przykazaniu miłości. 5 (1977) 238-244

HANICH Andrzej ks., Paschalny charakter chrześcijańskiej śmierci. 3 (1980) 163-167

HARATYM Edward SJ., Nauka św. Pawła o odkupieniu w świetle najnowszych badań. 1-3 (1956) 60-82

- N. Maryja Panna w Starym Testamencie. 1 (1951) 135-142

- Ostatnie chwile ks. Jakuba Wujka TJ. 3 (1948) 172-174

- Proroctwo Daniela o 70. tygodniach w egzegezie ostatniej doby. 1 (1949) $39-48$ 
HARĘZGA Stanisław ks., En pneumati jako zasada interpretacji Pisma św. we wschodniej tradycji Kościoła. 3-6 (1990) 111-121

- Ku pogłębionej odnowie biblijnej. 5-6 (1989) 372-376

- Lectio divina $\mathrm{w}$ formacji biblijnej seminarium duchownego. 6 (1988) 517528

- Mt 19, 16-22 źródłem nauki moralnej w encyklice „Veritatis splendor”. 1 (1994) 48-52

- Rozwój paschalnego prawodawstwa w świetle tradycji biblijnych Starego Testamentu. 3 (1984) 190-200

- Światowe inicjatywy apostolatu biblijnego w Bulletin Dei Verbum Katolickiej Federacji Biblijnej. 4 (1994) 256-262

- Uwagi na temat projektu końcowego dokumentu II Polskiego Synodu Plenarnego „Posługa Słowa”. 4 (1998) 284-292

- Znaczenie dokumentu Papieskiej Komisji Biblijnej „Interpretacja Biblii w Kościele". 1 (1996) 38-43

HARTLIEB Stanisław ks., Msza za zmarłych kapłanów. 1-2 (1974) 75-76

- Nowe obrzędy pogrzebowe a zwyczaje polskie. 1-2 (1974) 54-65

- Propozycje napisów nagrobkowych. 1-2 (1974) 103-106

HELLO Ernest, Amen-rozważanie (przekł. Irena Węsierska). 5-6 (1952) 475-480

- De profundis — rozważanie (przekł. Irena Węsierska). 2 (1955) 164-168

— Myśli o Piśmie świętym (przekł. Irena Węsierska). 1 (1952) 70-73

— Szkice rozważań (przekł. J. Węsierska). 1 (1953) 160-166

- Znaczenie łez w Piśmie świętym — rozważanie (przekł. Irena Węsierska). 4 (1952) 338-342

HENTSCHEL Georg ks., Historyczne podstawy tradycji o proroku Eliaszu. 2 (1980) 49-58

HERGESEL Tomasz ks., Adoracja Cudotwórcy — Mateuszowa interpretacja cudów Jezusa. 2-3 (1979) 104-114

- Biblia czytana w Afryce. 3-6 (1990) 144-155

- Cuda Jezusa w interpretacji św. Marka. 5 (1978) 230-239

- Cud w interpretacji autorów biblijnych. 2 (1981) 105-113

- Historia zbawienia według św. Mateusza. 1-3 (1991) 23-36

- Legenda o Józefie cieśli w kulcie oblubieńca Matki Bożej. 4-5 (1974) 221-230

- Motyw uwielbienia Boga w Łukaszowej interpretacji cudów Jezusawielkiego proroka. 5 (1981) 263-273 
- Nieznane słowa Chrystusa. 1 (1978) 28-35

HERRMANN Teofil CM, Czytanie Pisma świętego w świetle Soboru Watykańskiego II. 1-2 (1968) 40-47

- Grzech, który sprowadza śmierć (1 J 5, 16). 2-3 (1979) 115-124

- Międzyseminaryjny konkurs biblijny. 1 (1978) 39-40

- Międzyseminaryjny konkurs biblijny. 2 (1985) 175-177

- Obowiązki rodziców względem dzieci w Nowym Testamencie. 1-2 (1961) $32-52$

- Próba nowej interpretacji 1 J 5, 2. 4-5 (1975) 229-230

- Sprawozdanie z międzyseminaryjnego konkursu biblijnego. 6 (1985) 408409

- Wpływ Słowa Bożego na działalność św. Wincentego a Paulo (homilia). 2 (1985) 169-173

HOFFMANN Kazimierz ks., Cześć świętych w Kościele ewangelickim. 4 (1963) 223225

- Elementy ekumeniczne w mariologii soborowej. 1-2 (1968) 84-87

HOJKA Jerzy, Sodoma i Gomora. 6 (1961) 284-291

HOLCER Zygmunt., Czy mamy podobiznę świętej Jadwigi królowej Polski? 3 (1997) $187-200$

HOŁA Kazimierz ks., Diakon jako szafarz Komunii św. 4 (1977) 202-209

- Paschalny charakter Ostatniej Wieczerzy a data śmierci Jezusa. 1 (1985) 41-44

- Przymierze małżeńskie w świetle nauki Pisma św. i Tradycji. 6 (1987) 488-498

- Tajemnica Eucharystii w aspektach dziejoznawczych i dogmatycznych. 4 (1987) 314-322

- Ustanowienie sakramentu namaszczenia chorych. 6 (1966) 362-371

- Zagadnienia kontrowersyjne w teologicznej nauce o sakramencie namaszczenia chorych. 3 (1967) 146-154

HOMERSKI Józef ks., Dyskusje nad istotą natchnienia biblijnego. 5 (1964) 261-274

- Ekumenizm a Biblia. 1-2 (1968) 25-32

— „Kamień, który stał się wielką górą” (Dn 2, 31-45). 3 (1974) 148-156

- Słowo Boże a religijna formacja rodziny. 6 (1980) 314-324

— Śp. o. Ludwik Semkowski (1871-1977). 6 (1977) 338-340

— Wódz duchowy narodu wybranego na wygnaniu. 2-3 (1969) 57-74 
- Współczesne poglądy na strukturę i formę literacką mów prorockich o narodach. 4-5 (1971) 193-196

HORAK Tomasz ks., O nowy przekład Listu do Hebrajczyków. 2-6 (1992) 83-86

HÖSLINGER Norbert ks., Drogi i środki służące przybliżeniu Biblii ludziom. 1 (1987) 83-92

HRYNIEWICZ Wacław ks., Homo paschalis. 5 (1986) 447-448

HYRA Zygmunt ks., Formacja fonetyczna lektora. 4-5 (1971) 209-223

JABŁOŃSKI Zachariasz OSPPE, Śp. o. Rufin Józef Abramek OSPPE (1937-1990). 1 (1995) 61-66

JAGIELSKI Mirosław TChr, Śp. ks. prof. Theodor Schnitzler. 1 (1983) 53-54

JAGOSZ Michał ks., O świętej Jadwidze mówią. 1 (1998) 57-63

- Sympozjum ku czci świętej Jadwigi królowej w Rzymie w XIX. rocznicę inauguracji pontyfikatu Jana Pawła II. 1 (1998) 64-65

JAKUBIEC Czesław ks., Czy Hebrajczycy byli w Egipcie? 4-6 (1951) 341-352

- Historyczna tradycja żydowska. 5-6 (1950) 340-350

— Izrael. 5 (1952) 379-391

— Kiedy Izraelici wyszli z Egiptu? 5 (1949) 370-372

- Objawienie Boże w księdze Hioba. 5-6 (1973) 248-261

- Pascha. 2 (1949) 134-140

- Prorok i hagiograf. 2-3 (1979) 66-73

- Uniwersytet hebrajski w Bejrucie. 1 (1949) 61-66

— Ważny dokument. 5-6 (1948) 282-287

- W obronie Starego Testamentu. 3 (1952) 208-217

- Wzajemne ,przenikanie się” obu Testamentów. 1 (1963) 25-29

JAN XXIII, Z homilii wygłoszonej w dniu 23 XI 1958 przy objęciu katedry rzymskiej — Ksiega i Kielich (przekł. benedyktynów tynieckich). 4 (1959) 329-332

JANCZAK Adolf SCJ, Odpowiedzialność za śmierć Chrystusa. 6 (1966) 345-353

JANICKI Jan Józef ks., XXIX spotkanie wykładowców liturgiki (Warszawa 1993). 2 (1994) 125-129

- Eucharystia - centrum i wypełnieniem Misterium Paschalnego. 3-4 (1993) 148-156

- Misterium paschalne Chrystusa centralnym wydarzeniem życia Kościoła. 4 (1996) 236-248

- Pascha - centrum roku liturgicznego Starego i Nowego Ludu Bożego. 2 (1998) 101-115 
- Św. Stanisław, biskup i męczennik — główny patron Polski. 3 (1997) 203209

- Teologia modlitw za zmarłych w mszale rzymskim Pawła VI i Liturgii Godzin. 3 (1980) 113-126

- Teologia pastoralna - Liturgika - Instytut Liturgiczny w 70 lat po konstytucji „O liturgii”. 4 (1995) 243-254

JANKOWSKI Augustyn OSB, Aktualność apokaliptycznych listów do siedmiu Kościołów (Ap 2 i 3). 3 (1959) 260-277

- Biblijne pojęcie świętości człowieka. 2 (1984) 109-118

- Codzienne spotkanie z żywym Słowem Bożym. 4 (1958) 335-342

- Doniosłość Łukaszowej eschatologii indywidualnej. 4-5 (1975) 168-182

- Dwie świątynie Ducha Świętego według listów Pawłowych. 1 (1998) 1729

- Dwojakie orędzie eschatologiczne ( $\operatorname{~k~6,~6-26;~} 1$ Kor 7, 25-31) (homilia). 4-6 (1991) 129-130

- Elementy teologii męczeństwa w Liście do Filipian. 1 (1962) 160-166

- Eucharystia jako „Nowa Pascha” (1 Kor 5, 7) w teologii biblijnej Nowego Testamentu. 3 (1975) 89-100

- Homilie wielkopostne na rok A. 1 (1972) 48-61

- Horyzonty kosmiczne odkupienia w teologii biblijnej. 1 (1966) 23-44

- Idea wyzwolenia w listach św. Pawła. 2 (1987) 110-119

- Jezus a Duch. 1 (1983) 16-21

- Mater Ecclesiae. 4 (1965) 183-205

- Międzynarodowy Kongres Teologów Pneumatologów (Rzym 22-26 III 1982). 6 (1982) 434-438

- Misterium mortis. Synteza biblijnej nauki o śmierci. 1 (1978) 9-15

- Niepodzielnie oddany Panu (homilia). 3 (1986) 279-280

- Novi et Aeterni Testamenti. 3 (1957) 169-179

- Od Ducha Jahwe do Ducha Parakleta. Proces tworzenia się pneumatologii Nowego Testamentu 1 (1977) 54-65

- Papieska Komisja Biblijna dawniej i dziś. 5 (1980) 269-275

- Papieska Komisja Biblijna w nowym składzie. 2 (1985) 173-174

- Pismo święte na ambonie ze stanowiska biblistyki. 1 (1958) 1-14

- Początki Łukaszowej mariologii. 4 (1988) 320-329

- Rozwój nauk biblijnych a potrzeby duszpasterstwa polskiego. 2 (1959) $161-174$ 
- Sesja plenarna Papieskiej Komisji Biblijnej (1988). 3 (1988) 231

— Sesja plenarna Papieskiej Komisji Biblijnej w Rzymie. 6 (1985) 406

— „Słudzy Słowa” (Łk 1, 2). 1 (1979) 58-60

— „Tajemnica to jest wielka” (Ef 5, 32). 1-2 (1961) 32-42

- Transcendencja Chrystusa według Apokalipsy. 2 (1994) 82-95

— W sprawie rzekomego mesjanizmu czwartej eklogi Wergiliusza. 6 (1962) 362-371

- Wymiar pneumatologiczny chrystologii. 1 (1982) 1-11

— „Wzór macie w nas” (Flp 3, 17). Kształtująca się osobowość apostoła Pawła w świetle jego Listu do Filipian. 5 (1962) 265-276

— Ze wspomnień o śp. ks. Wojciechu Danielskim. 5 (1986) 449

- Z teologii prezbiteratu w dokumentach II Soboru Watykańskiego. 1 (1969) 21-33

JANOW Jan, Nowy ewangeliarz polski z XVI wieku (ewangeliarz puławski). 5-6 (1948) 318-339

JAN PAWEŁ II, Homilia podczas Liturgii Słowa przed wystawionym Całunem w katedrze turyńskiej w dniu 24 maja 1998 r. 3 (1998) 218-221

- Przemówienie w kościele św. Anzelma w Rzymie w 25. rocznicę założenia Papieskiego Instytutu Liturgicznego. 1 (1987) 71-74

JARZYNA Stanisław SCJ, Trzysta lat istnienia i działalno ści SS. Wizytek w Krakowie (1681-1981). 3 (1983) 231-238

JAWORSKI Jan ks., Mąka na hostie w świetle św. Tomasza a prawa kanonicznego. 5 (1949) 372-375

JAWORSKI Marian ks., Świadek naszych czasów i wiary współczesnego Kościoła. spec. (1979) 9-15

JELONEK Tomasz ks., Biblijne pojęcie wolności. 4 (1988) 347-353

— Eucharystia i Kościół. Aspekt biblijny. 5 (1980) 280-283

- Kamień na Syjonie i Góra Syjon. Dwa obrazy nowotestamentalnej eklezjologii. 6 (1978) 290-296

— Kongres Biblistów Polskich w Wagrowcu (26-28 maja 1973 r). 5-6 (1973) 319-321

- Lingwistyka matematyczna jako narzędzie badania Pisma świętego. 1 (1979) 56-57

- Posoborowa odnowa biblijna w duszpasterstwie. 6 (1986) 469-477

- Postać Mojżesza w Nowym Testamencie. 2-3 (1973) 107-110

- Poświadczające dzieła Boga według Hbr 2, 4.1 (1978) 16-22 
- Rodzaje nowotestamentalnej typologii Mojżesz-Chrystus. 4-5 (1974) 211215

— Rola Ducha Świętego według Listu do Hebrajczyków. 2 (1981) 119-129

- Sprawozdanie z działalności Polskiego Towarzystwa Teologicznego w Krakowie w roku 1980. 5 (1981) 306-310

- Sprawozdanie z sympozjum biblistów polskich w Rokitnie (1984). Lista uczestników sympozjum. 2 (1985) 177-180

- Teologia historii w nauczaniu Jana Pawła II. 1 (1980) 15-19

- XIII Kongres Biblistów Polskich. 6 (1975) 279-280

— Wielkość i rola Słowa Bożego według Listu do Hebrajczyków. 2 (1980) 79-93

— Zbawcze znaczenie Łukaszowego „dzisiaj”. 3 (1975) 107-113

JELITO Józef ks., Bóstwo Fenicjan w świetle nowych odkryć. 4 (1952) 311-327

- Działalność proroków Starego Testamentu. 1-2 (1950) 122-136

- Nimrod. 1-3 (1956) 5-9

- O historiografii biblijnej i starowschodniej. 1 (1949) 9-18

- Syria w czasach przedhellenistycznych. 1 (1952) 11-34

- Światopogląd starowschodni a biblijny. 1 (1948) 21-31; 3 (1948) 144-152

— „Tu es sacerdos in aeternum secundum ordinem Melchisedech” (Ps 109, 4). 5-6 (1950) 251-264

— Wiara w sny na Wschodzie Starożytnym. 2-3 (1955) 69-84

JEMIELITY Witold ks., Chrzest w XIX wieku w diecezji augustowskiej czyli sejneńskiej. 1 (1973) 15-19

JEZIERSKA Ewa Józefa OSU, Eucharystia udziałem wiernego w śmierci i zmartwychwstaniu Chrystusa. 1 (1985) 8-15

- Motyw śmierci i zmartwychwstania wiernych z Chrystusem w Flp 3, 1011.3 (1986) 250-259

- Preegzystencja chrześcijanina w ujęciu 2 Kor 5, 15.1 (1988) 40-43

— „Przemieniamy się w Jego obraz” (2 Kor 3, 18). 2 (1986) 112-120

JEZIERSKI Jacek ks., Śp. ks. Jerzy Wirszyło (1901-1990). 3-6 (1990) 168-169

JEZUSEK Wacław ks., Arcybiskup Antoni Julian Nowowiejski — biskup płocki (1908-1941). 4-5 (1955) 198-205

JEŻOWSKI Lesław ks., O Ormianach i liturgii ormiańskiej. 5 (1959) 493-510

- Siostra Maria Renata a liturgia. 3 (1957) 200-212

- Tematyka biblijna na ekranie. 4 (1959) 397-406

JĘDRZEJEWSKI Sylwester SDB, Apokaliptyka jako rodzaj literacki. 1 (1998) 29-35 
- Dialogiczność Przymierza a początek grzechu. 4 (1997) 276-282

JOŃCZYK Alicja RM., Odnowione obrzędy pogrzebu. 5 (1979) 266-275

Kalendarium biograficzne o. Augustyna Jankowskiego OSB. 1 (1997) 60-64

KANTOR Maria, Forum „Ewangelizacja 2000” (Kraków 1994). 4 (1994) 282-283

- „Jezus nadzieja Europy”. Kongres Liderów Europejskich w Bernie (1990). 4-6 (1991) 148-149

- Kronika archeologiczna (Tajemnica pustyni judzkiej. Nowe odkrycia w grotach nad Morzem Martwym. Nowe wykopaliska w Izraelu. Ukryte skarby starożytne. Zagadka świątyni w Luxor). 1-3 (1991) 76-78

- VII spotkanie Stowarzyszenia Koordynatorów Katolickich Szkół Ewangelizacyjnych (Kraków 1995). 2 (1995) 139-141

- VI Europejskie seminarium odnowy parafii (Mediolan 1995). 3 (1995) 219-220

- VI Spotkanie Stowarzyszenia Koordynatorów Katolickich Szkół Ewangelizacyjnych w Mediolanie (1994). 2 (1994) 130-131

KAPERA Zdzisław, Chirbet Qumran: Osiedle mnichów czy villa rustica? 1 (1996) 1828

- Curriculum vitae ks. Aleksego Klawka. 4 (1980) 221-227

- IV Międzynarodowe Kolokwium Qumranologiczne (Kraków-Swoszowice 1993). 1 (1994) 57

- Drugie Międzynarodowe Kolokwium Qumranologiczne (KrakówMogilany 1989). 3-6 (1990) 160-162

- Działalność naukowa ks. Ludwika Stefaniaka CM (1930-1972). 2-3 (1973) 130-139

- Interpretacje archeologiczne osiedla qumrańskiego. Zwięzły przegląd hipotez w pięćdziesięciolecie odkryć nad Morzem Martwym. 4 (1997) 237250

- Nowe odkrycia w Jerozolimie (1961-1963). 4 (1965) 230-235

- O pełniejszą ocenę dorobku onomastycznego ks. Aleksego Klawka. 4 (1989) 201-207

- V Międzynarodowe Kolokwium Qumranologiczne (Kraków-Zakrzówek 1995). 4 (1995) 296-297

- Pierwsze teksty Filistynów. 4-5 (1972) 265-268

- III Międzynarodowe Kolokwium Qumranologiczne (Kraków-Mogilany 1992). 1 (1992) 41-43

— Życie i działalność ks. Jeana Carmignaca (1914-1986). 2 (1987) 119-132 
KAPLIŃSKI Piotr ks., Czy w Dziejach Apostolskich istnieje terminologia wskazująca na pasterski autorytet św. Piotra. 5-6 (1989) 368-372

KARPIŃSKI Ryszard ks., Nierozerwalność małżeństwa w Nowym Testamencie Mt 5, 32 i $19,9.2$ (1965) 77-88

- Władza nauczycielska Chrystusa w Ewangelii św. Mateusza. 4-5 (1969) 206-213

KARPLUK Maria, W maryjnym skarbcu polskiego Kościoła - Godzinki. 1 (1994) 25-29

KAZNOWSKI Zbigniew ks., Biblijno-krajoznawcza wycieczka do Syrii i Libanu. 3 (1975) 139-142

- Drugi Międzynarodowy Kongres Uczonych Starego Testamentu. 4-6 (1956) 299-301

- Ewolucja roku liturgicznego. 3-6 (1954) 215-219

- Hadajoth. 6 (1957) 436-444

- Piąty Międzynarodowy Kongres Biblijny w Oxfordzie. 5-6 (1973) 324326

KELER Konrad SVD, IV sesja plenarna Katolickiej Federacji Biblijnej (Bogota 1990). 1 (1992) 39-41

KEMPF Zdzisław, „Ręce pająka” w Prz 30, 28.1 (1985) 1-8

KEMPIAK Ryszard SDB, „Biblia i ewangelizacja”. Biblijne spotkanie salezjańskie w Lyonie 1991. 4-6 (1991) 147-148

— Sympozjum „Młodzi i Biblia” (Rzym 1992). 1 (1992) 43

KIEŁBASA Antoni SDS, Śp. ks. Jan Drozd (1914-1966). 3 (1997) 215-218

KLAWEK Aleksy ks., Amman. 4 (1948) 251-253

- Antyfony na Nowy Rok. 1 (1948) 19-20

- Ave Maria. 1 (1951) 25-37

- Betlejem. 6 (1949) 446-448

- Biblijne symbole maryjne. 4-6 (1956) 216-227

- Chrystus pod Jerycho. 5 (1965) 293-300

- Dekret Stolicy Apostolskiej w sprawie historyczności ksiąg świętych. 5 (1962) 305-308

— De profundis (Ps 130 [129]). 5-6 (1950) 260-266

- Dokument historyczny o Nazaret. 4 (1965) 235-266

- Dominus regnavit (Ps 93 [92]). 4 (1962) 197-203

- Droga krzyżowa. 2 (1965) 89-104

- Dwie drogi. 1 (1952) 5-11 
- Ewangelie i ewangeliści (godzina biblijna). 1 (1963) 56-60

- Godzina biblijna o Nazarecie. 5-6 (1963) 291-298

- Hymn anielski (Łk 2, 14). 2-3 (1970) 65-72

- Hymn Anny matki Samuela. 1 (1954) 1-4

— Hymn ku czci Stworzyciela (Ps 104 [103]). 3 (1949) 149-154

- Imię Maria. 1 (1951) 56-58

- Instrukcja Komisji Biblijnej w sprawie historyczności Ewangelii. 4 (1964) 197-207

- Jahwe pasterzem naszym (Ps 23). 3 (1952) 195-205

- Jahwe twierdzą naszą (Ps 46). 2 (1952) 100-108

- Jezus naucza w synagogach. 4-5 (1966) 255-260

- Jubileusz Biblii ks. Wujka. 1-2 (1950) 7-16

- Kafarnaum a Najświętszy Sakrament. 6 (1968) 369-373

— Ks. Józef Kaczmarczyk (1871-1951). 3 (1952) 205-207

- Laudate Dominum omnes gentes (Ps 117). 3 (1951) 244-250

- Miasto święte Jeruzalem. 6 (1964) 355-361

- Misterium o Męce Pańskiej św. Katarzyny z Ricci. 2 (1948) 52-54

- Modlitwa pobożnego biedaka (Ps 26). 4 (1952) 284-295

- Modlitwa za święte Miasto (Ps 122). 4 (1949) 227-229

- Msze św. ku czci Matki Bożej Niepokalanej. 2 (1954) 176-193

- Nabożeństwo liturgiczne w kościołach ewangelickich. 6 (1965) 357-365

- Najstarszy rękopis Ewangelii św. Mateusza. 1 (1964) 50-51

- Niebo i ziemia niechaj Pana chwalą (Ps 148). 4-6 (1951) 333-341

— Nieszpory polskie w nowym przekładzie. 1 (1965) 48-53

- Nowa struktura teologii współczesnej. 1 (1965) 2-14

— Nowe „Miserere” (Ps 50 [51]). 2 (1954) 61-68

- Nowe wykopaliska w Bet-Sean. 6 (1962) 373

- Nowy rękopis Ewangelii św. Łukasza. 5 (1962) 308-309

— Odbudowanie wieży Babel. 6 (1962) 373

- Osiem błogosławieństw (godzina biblijna). 2 (1967) 103-107

- Quam admirabile est nomen Tuum (Ps 8). 1 (1948) 6-9

- Quis cognovit sensum Domini. 6 (1968) 306-318

- Pan stróżem jest (Ps 121). 4 (1948) 196-200

— Pierwsze proroctwo (Gen 3, 14-15). 2-3 (1963) 124-133 
- Pieśń dziękczynna (Ps 103). 1 (1949) 4-6

- Pieśń o stworzeniu (Rdz 1, 1 — 2, 4). 3 (1962) 146-153

- Pieśń wygnańca (Ps 122). 3 (1948) 123-126

- Pogląd na prace teologów polskich w XX wieku. 2 (1966) 131-143

- Po spowiedzi (Ps 132). 2 (1949) 77-80

- Proza ku czci Matki Bożej Wniebowziętej z XIV wieku. 1 (1951) 89-97

- Przed jutrzenką cię zrodziłem (Ps 109). 5-6 (1948) 268-271

- Przy pustym grobie. 2 (1964) 104-109

- Psalm Miserere. 1 (1966) 45-51

— Psalm 148 a sztuka kościelna. 1 (1952) 82-83

— Psalm o Opatrzności Bożej (Ps 90) — godzina biblijna. 3 (1966) 198-202

- Raj i upadek człowieka. 4-5 (1969) 288-295

- Recytacja psalmów po hebrajsku. 6 (1962) 373

- Słowacki o Biblii i Ziemi Świętej (w setną rocznicę zgonu poety 18491949). 4 (1949) 230-239

- Smutna dola nasza (Ps 90). 5 (1949) 309-318

— Spokój duszy pokornej (Ps 131). 6 (1949) 370-381

- Stworzenie wszechświata. 3 (1968) 180-189

- 60-lecie kapłaństwa o. Wincentego Rejmera OFMRef. 6 (1965) 379-380

— Śp. ks. Ferdynand Machay (1889-1967). 4-5 (1967) 193-196

- Św. Paweł przybywa do Europy. 3 (1965) 175-180

— Tajemnice Boże u św. Pawła (według Listu do Efezjan). 6 (1965) 366-371

- Tęsknota za Bogiem (Ps 62). 2 (1948) 57-64

- Tęsknota za Jerozolimą (Ps 42 [43]). 4-5 (1955) 173-184

- Tło polityczne Ps 87. 5-6 (1948) 348-349

— Uwagi do konstytucji „O Bożym Objawieniu”. 1 (1966) 26-32

- Uwagi do Psalmu 68. 1 (1956) 26-29

- Witamy Stwórcę świata. 2 (1951) 147-162

- Wspomnienie o śp. ks. prof. dr. Józefie Jelito. 2 (1967) 112-114

- Współczesna interpretacja ksiag Starego Testamentu. 4-5 (1969) 185-199

— Wykopaliska w Teleilat Ghassul. 6 (1962) 373

- Zginamy kolana przed Bogiem-Stworzycielem naszym (Ps 94). 6 (1967) 366-370

— Zmiany liturgiczne w świetle historii. 5 (1965) 273-279 
KLEJDYSZÓWNA Krystyna OSB, Profesja zakonna tajemnicą zaślubin. 1-2 (1961) $58-61$

KLINGER Wacław, O czasie powstania Apokalipsy Janowej. 1 (1953) 133-147

— Św. Paweł Apostoł a obszar Macedonii i Helady. 4-5 (1955) 195-198

KŁONIECKI Felicjan ks., Metoda nauczania Pisma św. w polskich seminariach i instytutach teologicznych. 4 (1959) 345-361

KŁÓSAK Kazimierz ks., Sprawozdanie z działalności Polskiego Towarzystwa Teologicznego w Krakowie w r. 1957/58. 2 (1959) 200-202

KNABIT Leon OSB, Ojciec święty w Nowym Targu. 1 (1980) 25-29

KOCOŃ Marek, Refleksja na pożegnanie. 1 (1980) 38

KOKOT Mirosław SDB., Znaczenie nasienia w przypowieści o siewcy. 2-3 (1973) 99107

KOŁECKI Jan, Pozostanie w pamięci. 6 (1983) 518

KOŁODZIEJCZYK Miłosław ks., Cel wzrostu Mistycznego Ciała Chrystusa w świetle Listu św. Pawła do Efezjan. 5 (1962) 277-282

- Dalsza reforma w dziedzinie odpustów. 2-3 (1969) 103-123

- Fakt wzrostu Mistycznego Ciała Chrystusa w świetle Pisma św. 2 (1962) 91-101

- Nowa miara odpustu częściowego. 3 (1968) 147-158

— Reforma obrzędów sakramentu bierzmowania 3 (1972) 189-196

- Teologiczne założenia praktyki odpustowej. 3 (1974) 138-147

KOMASA Michał ks., Znaczenie metafory skolops te sarki (2 Kor 12, 7). 3 (1958) 211-230

Komunikat Towarzystwa Biblijnego w Polsce. 2 (1995) 141; 4 (1995) 297-299; 1 (1996) 55-58; 2 (1996) 127-129; 2 (1997) 161-162

KONECKI Krzysztof ks., Zasady interpretacji tekstów euchologijnych. 3-4 (1993) 176-183

KONDRACKI Andrzej SDB, XXXVI sympozjum biblistów polskich (Poznań 1998). 4 (1998) 305-306

KOŃCZYK Adam ks., Psalm 58 w świetle krytyki literacko-historycznej. 2-3 (1973) 67-78

KOPEĆ Edward ks., Chrystologia w świetle historii zbawienia. 1 (1953) 74-83

- Chrystus w Koranie. 1 (1955) 15-23

- Ile lat liczy manuskrypt z pustyni judzkiej? 5-6 (1950) 373-375

- Koran a Biblia. 3 (1952) 263-272

- Objawienie. 3 (1949) 158-165 
KOPEĆ Jerzy Józef CP, Homilia w archikatedrze warszawskiej podczas uroczystej Eucharystii pożegnania księdza dra Wojciecha Danielskiego przez Katolicki Uniwersytet Lubelski w dniu 30 XII 1985 r. 5 (1986) 436-441

- Liturgia źródłem formacji życia chrześcijańskiego według ks. Wojciecha Danielskiego. 5 (1986) 399-419

- Małe oficja i godzinki staropolskie. 1-2 (1990) 42-56

- Ruch liturgiczny, reforma i odnowa liturgiczna. 4-5 (1985) 265-285

KOPEĆ Jerzy Józef CP, LENART Emilian OFM, WIT Zbigniew ks., Śp. ksiądz dr Wojciech Danielski (1935-1985). 5 (1986) 373-376

KOPIEC Jan ks., Księga przystępujących do Komunii św. z Wysokiej (diecezja opolska) z lat 1766-1849. 2 (1983) 147-149

— Śp. ks. Antoni Kubik (1926-1978). 5 (1978) 277-278

KOPEREK Stefan CR, Cechy interwencji kapłana w liturgii Mszy św. 6 (1980) 344350

- Dom Lambert Beauduin - prekursor współczesnej odnowy liturgicznej. 4 (1973) 209-217

- Dom Prosper Gueranger - opat z Solesmes inspirator współczesnej odnowy liturgicznej. 4 (1976) 213-220

— 20 lat działalności Instytutu Liturgicznego w Krakowie. 1-2 (1990) 69-78

- IX Międzynarodowy Kongres Liturgiczny (Societas Liturgica). 2 (1984) 144-148

- Eucharystyczne adoracje kapłańskie. 6 (1985) 418-458

— XI Kongres „Societas Liturgica” (1987). 5 (1988) 442-447

- Ks. Michał Kordel w kontekście polskiego ruchu liturgicznego. 2 (1988) 136-155

- Międzynarodowy Kongres Serca Jezusowego (Tuluza 1981). 6 (1981) 389-393

- Odnowa liturgii w męskich wspólnotach zakonnych. 4-5 (1985) 339-354

- Polskie kongresy eucharystyczne. 4 (1986) 325-344

- Posługa siostry zakrystianki. 1-3 (1991) 53-63

- Sesja Polskiego Towarzystwa Teologicznego w Krakowie poświęcona śp. ks. prof. Wacławowi Schenkowi. 6 (1983) 521-522

- Synod krakowski o kulcie eucharystycznym. 5 (1980) 288-290

- Wkład ks. prof. Wacława Schenka w Papieski Wydział Teologiczny w Krakowie. 6 (1983) 499-507

KORHERR Edgar Joseph, Katecheza i diakonia (caritas). 2 (1986) 155-172 
KORPUSIK Andrzej ks., Stworzenie świata w kolektach Mszału Pawła VI. 4 (1987) 305-314

KOSECKI Bolesław ks., Historia sakramentu bierzmowania. 1-2 (1975) 19-24

- Intelligentia Mysterii w posoborowej teologii liturgii. 2-3 (1971) 109-123

— Problem homilii chrzcielnej. 2 (1972) 97-104

- Wyznanie grzechów w praktyce pokuty Kościoła na Zachodzie. 2-3 (1976) 65-81

KOSOWSKI Stanisław ks., Dobre czyny w nauczaniu św. Duszpasterza w Galacji. 1 (1958) 38-42

- Miłość bliźniego w ujęciu św. Pawła Apostoła (Refleksja na tle Listu do Galatów). 4 (1957) 261-266

- Modlitwa św. Pawła za wiernych. 5 (1959) 473-484

- Odpustowa Msza św. 2-3 (1963) 145-148

- Św. Paweł i jego praca apostolska w zasięgu modlitw wiernych. 6 (1961) 325-329

KOSTECKI Romuald OP., Obecność Chrystusa w Eucharystii w świetle encykliki Pawła VI „Mysterium fidei”. 1 (1967) 32-39

— W jaki sposób Eucharystia gładzi grzechy lekkie. 3-4 (1960) 321-330

— Zbawienie niewiernych według Vaticanum II. 4-5 (1968) 209-220

KOTYŃSKI Leon ks., Metryka hymnów brewiarzowych. 4 (1958) 292-317

KOWALAK Władysław SVD, Obrzędy oczyszczające w afrykańskich kultach synkretycznych. 2-3 (1976) 117-127

KOWALCZYK Andrzej ks., Dlaczego Marek napisał drugą Ewangelię? 2 (1986) 107120

- Rola tematu „Działalność Jezusa - nowym wyjściem i nowym podbojem Ziemi Obiecanej” w redakcji Ewangelii św. Mateusza. 2 (1985) 134-159

- Wpływy Heksateuchu na dobór perykop w częściach narracyjnych Ewangelii Mateusza. 1 (1987) 26-39

KOWALEWICZ Henryk, Dwie prozy maryjne. 4 (1958) 332-334

— Hymn na święto Matki Bożej Śnieżnej. 1 (1958) 63-65

- Hymn na święto translacji św. Wojciecha. 4 (1957) 280-288

KOWALSKA Zofia, Notker Füglister OSB (1931-1996). 3 (1997) 223-224

KOWALSKI Jan ks., Biblijno-liturgiczna orientacja św. Franciszka Salezego (w czterechsetlecie urodzin). 4-5 (1967) 289-293

- Działalność Polskiego Towarzystwa Teologicznego w Krakowie w roku 1976. 4 (1977) 221-224 
- Ks. infułat Jan Domarańczyk (1895-1978) liturgista i kapłan. 2-3 (1979) 169-171

- Naukowe sympozjum ekumeniczne i biblijne w Krakowie. 6 (1967) 377380

— Pielgrzymka Pawła VI do Ziemi Świętej. 6 (1964) 334-339

- Pismo św. w twórczości ascetycznej Mikołaja z Mościsk (1559-1632). 2 (1967) 85-93

- Refleksje moralisty na marginesie „Redemptor hominis”. 6 (1979) 336340

- Sprawozdanie z działalności Polskiego Towarzystwa Teologicznego w Krakowie za rok 1965/1966. 6 (1966) 381-383

- Sprawozdanie z działalności Polskiego Towarzystwa Teologicznego w Krakowie w roku 1972. 5-6 (1973) 326-328

- Sprawozdanie z działalności Polskiego Towarzystwa Teologicznego w Krakowie w roku 1973. 4-5 (1974) 282-284

- Sprawozdanie z działalności Polskiego Towarzystwa Teologicznego w Krakowie w roku 1974. 6 (1975) 281-283

- Sprawozdanie z działalności Polskiego Towarzystwa Teologicznego w Krakowie w roku 1975. 5-6 (1976) 313-316

- Życie i działalność ks. dra Ferdynanda Machaya archiprezbitera bazyliki mariackiej w Krakowie. 4-5 (1967) 196-202

KOWALSKI Seweryn ks., Noli me tangere (J 20, 11-18). 2 (1949) 104-111

- Początki ewangelii Jezusa Chrystusa. 1-2 (1950) 136-148

- Spisek Heroda Antypy na życie Chrystusa Pana. 4-6 (1951) 380-385

— „Wielki znak na niebie” (Apokalipsa 12, 1-6). 2 (1951) 204-218

KOWALSKI-WIERUSZ Jan OSB, Echa encykliki „Mediator Dei”. 4 (1948) 263-264

- Liturgia podczas wojny i po wojnie. 1 (1948) 31-38

- Liturgia Wniebowzięcia. 1 (1951) 82-88

- Nasze wydawnictwa liturgiczne. 3 (1949) 188-191

- Niedziela dniem Pańskim. 2 (1948) 90-96

- Ruch liturgiczny za granicą. 1 (1952) 83-85

— Wiadomości liturgiczne. 3 (1948) 186-188

KOWOL Hubert ks., Ks. profesor Wacław Schenk jako kapłan i duszpasterz. 6 (1983) 486-493

KRAJEWSKA Wanda, Izajaszowe proroctwo radości. 6 (1961) 323-325 
KRAKOWIAK Czesław ks., Dedykacja ołtarza według Pontyfikału Rzymskiego z 1977 r. 6 (1981) 361-372

- Inkulturacja liturgii (XII Kongres „Societas Liturgica” 1989). 1-2 (1991) $65-70$

- Kapłaństwo wspólne i kapłaństwo służebne w świetle ksiąg liturgicznych. 4 (1983) 297-306

- Kierunki badań nad liturgią ks. W. Danielskiego. 5 (1986) 389-399

- Nazwa sakramentu bierzmowania. 1-2 (1975) 66-71

- Odnowiona liturgia sakramentu bierzmowania. 1-2 (1975) 24-31

- Sprawozdanie z XVIII sympozjum naukowego wykładowców liturgiki (Leżajsk 1981). 4 (1983) 335-336

- Zgromadzenie liturgiczne jako podmiot celebracji. 3 (1989) 168-178

- Z teologii wtajemniczenia chrześcijańskiego. 2-6 (1992) 65-74

KRASIŃSKI Józef ks., Biblijna orientacja teologii dogmatycznej. 1 (1967) 24-32

- Społeczny charakter Mszy św. według „Institutio Generalis - Missalis Romani”. 2-3 (1970) 92-104

KRAWCZYK Roman ks., Doktryna antropologiczna Rdz 1-3 jako motyw życia etycznego w księdze Syracha. 3 (1994) 176-183

— „Kimże jest człowiek” (Syr 18, 8)? U podstaw antropologii księgi Syracha. 2 (1985) 124-134

- Kobieta w świetle przekazów biblijnych. 6 (1987) 480-487

- Prorocy a kult. 3 (1987) 244-248

— Syrach a Rdz 1-3. 4 (1984) 298-297

KREFT Witold, Kościół jako zgromadzenie liturgiczne w Liście do Hebrajczyków. 4 (1973) 185-194

KRÓLIKOWSKI Janusz ks., Biblijne miejsce józefologii. 1 (1994) 42-48

KRUPPIK Jan ks., Rola liturgii w katechezie młodzieżowej. 4 (1965) 226-229

KRUSZYŃSKI Tadeusz ks., Wyobrażenia Chrystusa. 3 (1952) 246-253

- Zaśnięcie Najświętszej Maryi Panny w sztuce. 1 (1951) 124

— Złote róże. 2 (1948) 79-83

KRZAN Bronisław ks., Andrzej Krzycki liturgista polski XVI w. 4 (1948) 236-245

KUBIK Antoni ks., Terminologia soteriologiczna w Starym Testamencie (JahweZbawca). 6 (1965) 321-328

— „Wojna Synów Światłości z Synami Ciemności”. 6 (1957) 428-435

KUBIŚ Adam ks., Ks. prof. dr Eugeniusz Florkowski (w 50-lecie święceń kapłańskich). 1 (1976) 1-8 
- Praktyka penitencjarna męczenników w pierwotnym Kościele. 2-3 (1970) 87-92

— Tytuł „męczennik”. 5-6 (1976) 294-299.

KUDASIEWICZ Józef ks., Adaptacja tekstów biblijnych w Mszach św. z udziałem dzieci. 2-3 (1977) 113-126

- Czy są w Starym Testamencie mity? 5 (1965) 257-273

- Jedność obu testamentów jako zasada wyjaśniania misterium Chrystusa w Kościele pierwotnym. 2-3 (1971) 95-109

- Nowe formy apostolatu biblijnego. 5-6 (1973) 289-296

- Powstanie i historyczność Ewangelii w dyskusji soborowej. 1-2 (1968) 124

- Słowo Boże w nowych obrzędach pogrzebu. 1-2 (1974) 41-53

- Słowo Jezusa pełne mocy. 2 (1980) 101-105

KUJAWSKI Tadeusz ks., Msza święta za lud. 6 (1974) 327-336

KULESZA Zofia, Kapłan i duchowy kierownik ludzkich sumień. 5 (1986) 466-467

KUMOR Bolesław ks., Archidiecezja krakowska i jej organizacja terytorialna. spec. (1979) 80-95

KUŚ Jan ks., Cenna pamiątka z trumny św. Kazimierza w skarbcu katedry wawelskiej. 5-6 (1989) 376-378

- Kolegiata św. Floriana w Krakowie w kulturze religijnej Polski i Krakowa. (1184-1984). 4 (1984) 328-334

- Kościół i szpital św. Walentego na Kleparzu w Krakowie. 1 (1986) $42-49$

- Ks. Ferdynand Machay (1889-1967). W stulecie urodzin. 3 (1989) 235238

— Ks. prof. Władysław Smoleń (1914-1988). 1 (1989) 72-73

- Ołtarz św. Józefa w kościele mariackim w Krakowie. 2-3 (1979) 156-163

- Posag Matki Bożej Łaskawej z XVIII w. w Krakowie. 5 (1978) 263-265

- Szpitalny kościół św. Jadwigi na Stradomiu w Krakowie (Z dziejów kultu bł. królowej Jadwigi). 6 (1975) 259-265

- Wokół obrazu „Koło śmierci” w kościele św. Katarzyny w Krakowie. 3 (1983) 238-242

- Zwiastowanie w sztuce kościelnej. 1-2 (1968) 59-69

KUŚMIEREK Anna, Funkcja teologiczna danych topograficznych w czwartej Ewangelii. 5 (1989) 342-348

KUŹNIAK Krystyna FMA, Święto NMP Wspomożenia Wiernych w 150-lecie. 2 (1967) 94-102 
LABUDA Alfons SVD, Liturgia pogrzebu dziecka w dawnej Polsce. 4 (1981) 240-246

- Msza za zmarłych. 1-2 (1973) 29-41

— Teologia mszy pogrzebowej „Preaesente corpore”. 3 (1980) 145-162

LAMBRECHT Jan SJ, „Czy Ty jesteś tym, który ma przyjść, czy też innego mamy oczekiwać"? Współczesne odczytanie orędzia ewangelicznego Jezusa. 2 (1989) 85-97

LANGKAMMER Hugolin OFM, Dziewicza Matka - Rzeczywisto ść czy ideologia. 6 (1988) 471-486

- Homilia wygłoszona podczas Mszy św. 14 IX 1989 r. 1 (1989) 63-64

- Hymny pasyjne w Pierwszym liście św. Piotra. 5-6 (1973) 270-279

— J 2, 4 w świetle najnowszej egzegezy. 2 (1962) 82-91

- Męka Jezusa według Marka - objawieniem synostwa Bożego Jezusa. 3 (1974) 121-127

- O interpretacji cudów Jezusa. 4 (1978) 193-198

- Pismo święte w encyklice Jana Pawła II „Redemptoris Mater”. 3 (1988) 252-267

- Powrót Judejczyków z niewoli babilońskiej w świetle archeologii. 2-3 (1970) 72-76

— Próba nowej interpretacji ekstazy prorockiej. 4-5 (1971) 197-205

— „Sacris litteris inititur”. 3 (1995) 191-193

- Stary Testament a dzieło zbawcze w Chrystusie (Zagadnienie techniki hermeneutycznej w teologii św. Pawła). 1 (1979) 14-22

- Teologie Nowego Testamentu w języku polskim. 2 (1987) 169-172

- Uniżony i wywyższony Chrystus (Flp 2, 6-11). 4-5 (1975) 216-225

- Zagadnienie autentycznego brzmienia słów konsekracji. 3 (1975) 101-106 LANGOSZ Stanisław ks., Św. Atanazy a Biblia. 4-5 (1974) 237-246

LAWIESS George OSA, Augustyńskie brzemię posługi pastoralnej. 4 (1989) 294-301

LECH Stanisław ks., Odnowa liturgii w małych grupach. 4-5 (1985) 381-386

- Przestrzeń celebracji liturgicznych. 3 (1989) 187-198

LEMAIRE André, Aramejska inskrypcja wróżbity Balaama syna Beora. 2 (1987) 105110

- Historia początków starożytnego Izraela: Nowe kierunki badań. 2 (1987) 97-105

LEMPA Henryk ks., Badania nad Apokalipsą św. Jana we współczesnej biblistyce polskiej (1945-1985). 3 (1986) 259-274

— Symbolika eklezjalna w Apokalipsie św. Jana. 1 (1988) 25-40 
LEWANDOWSKI Bogumił ks., Zagadnienia liturgiczne na pierwszej sesji Synodu B iskupów. 1-2 (1968) 87-97

LEWICKI Tadeusz, Z dziejów orientalistyki lwowskiej. 4 (1980) 188-190

LIPIŃSKI Edward ks., IV Międzynarodowy Kongres Starego Testamentu. 6 (1962) 372-376

- Dwie tendencje w biblistyce. 6 (1962) 353-362

- XII Lowański Zjazd Biblijny. 5 (1960) 313-318

- Genesis 1, 1-2. 3 (1958) 177-189

- Godzina ukrzyżowania. 2 (1959) 126-137

- Istnienie Boga według ksiąg Starego Testamentu. 3-4 (1960) 193-198

- XI Biblijne Dni Lowańskie. 6 (1959) 593-595

- Kościół a Stary Testament. 5 (1960) 407-413

- Namaszczenie w Betanii. 3 (1959) 320-329

- Ostatnia uczta paschalna Starego Testamentu. 6 (1958) 480-488

- Pierwszy Międzynarodowy Katolicki Kongres Nauk Biblijnych. 6 (1958) 529-540

— XV Lowańskie Dni Biblijne. 5-6 (1963) 313-318

- III Międzynarodowy Kongres Starego Testamentu. 6 (1980) 596-600

- Trudności biblijne. Bóg pragnie zbawienia wszystkich ludzi (1 Tm 2, 2-4). 2 (1958) 134-140

LISOWSKI Marian OFMConv, Sprawozdanie z działalności Polskiego Towarzystwa Teologicznego w Krakowie w r. 1958/1959 i 1959/1960. 3 (1961) 171

LISZKA Józef ks., Ziemia Święta wczoraj i dziś. 4 (1952) 353-359

Liturgia na 40. Międzynarodowym Kongresie Eucharystycznym (Melbourne 18-25 luty 1973) — przekład ks. Bogdan Dziwosz. 4 (1973) 218-223

LUKKEN G. M., Czy liturgia ma przyszłość? 2-3 (1970) 112-127

ŁACH Jan ks., „Albowiem gniew Boży ujawnia się przeciw wszelkiej bezbożności” (Rz 1, 18). 3 (1987) 248-252

- Data Ostatniej Wieczerzy w świetle dokumentów znad Morza Martwego. 5 (1958) 404-417

- Idea Boga w księgach Kronik. 1 (1977) 18-26

- Jezus zrodzony z Maryi Dziewicy. 3 (1988) 242-252

- Ks. arcybiskup F. A. Symon jako biblista (w czterdziestą rocznicę śmierci). 1 (1958) 23

- Liturgiczny kalendarz Księgi Jubileuszów w świetle ostatnich dyskusji. 23 (1963) 98-105 
— „Nadzieją radujący” (Rz 12, 12). 1 (1992) 21-24

- Nowy kalendarz do czwartej Ewangelii. 4-5 (1970) 234-240

- Obowiązek pojednania i miłości (Mt 5, 43-48). 3 (1986) 231-243

- Ostatnia Wieczerza we współczesnej problematyce biblijnej. 2 (1959) 138-145

- Pieśń Anny, matki Samuela (1 Sm 2, 1-10). 3-4 (1961) 104-109

- Pokłon Magów (Mt 2, 1-12). 5-6 (1976) 260-270

— „... Ponieważ wszyscy zgrzeszyli” (Rz 5, 12). 6 (1959) 559-572

- Problem interpretacji genealogii 1 Krn 1-9. 2 (1985) 100-110

- Reguła Zrzeszenia z Qumran. 6 (1957) 417-427

- Relacja „złotej zasady postępowania” (Mt 7, 12) do nakazu miłości nieprzyjaciół (Mt 5, 43-48). 6 (1988) 457-465

- Samuel ostatni sędzia i pierwszy prorok Izraela. 6 (1967) 331-340

- Służebna rola Maryi w odkupieniu w świetle relacji o zwiastowaniu (Łk 1, 26-38). 6 (1981) 347-354

— XXXVI Tydzień Biblijny w Madrycie. 2 (1980) 108-110

- Uczta Zrzeszenia z Qumran a Ostatnia Wieczerza. 6 (1958) 489-497

- Walka Dawida z Goliatem (1 Sm 17, 1 - 18, 5). 5 (1964) 280-290

ŁACH Józef ks., Elizeusz jako sługa Eliasza i prorok Jahwe. 4 (1987) 273-280

- Jak ujmować w nowy sposób teologię w 1-2 Królów? 4 (1996) 240-255

- Modlitwa króla Salomona o mądrość (1 Krl 3, 6-15). 1 (1984) 41-45

- Modlitwy króla judzkiego Ezechiasza (2 Krl 19, 15-19; Iz 38, 3. 9-20). 5 (1987) 405-413

ŁACH Stanisław ks., Bóg psalmistów. 4 (1978) 178-184

- Geneza mesjanizmu biblijnego. 4-5 (1970) 161-179

- Hymny dziękczynne w Psałterzu. 4 (1977) 163-172

- Kim jest obiecany prorok w Pwt 18, 15n? 4-5 (1971) 188-192

— Kongres Biblijny w Madrycie. 6 (1978) 333-335

- Miejsce śmierci i zmartwychwstania Chrystusa. 2 (1958) 124-133

- Mojżesz i jego wielkość. 4-5 (1966) 216-225

- Natura manny biblijnej. 2-3 (1963) 65-71

- Pielgrzymka księży tarnowskich do Ziemi Świętej. 6 (1978) 335-338

- Pieśń Mojżesza w Pwt 32, 1-43. 2 (1964) 66-80

- Przedmowa (do nr. 4-5). 4-5 (1975) 145

- Przemówienie na XII Kongresie Biblistów Polskich. 4-5 (1975) 147-148 
- Przymierze na Synaju w świetle nowych dokumentów. 5 (1962) 257-265

— Psalm i błogosławieństwo Mojżesza (Pwt 33, 1-29). 2 (1965) 65-77

- Rekonstrukcja pierwotnego Dekalogu. 4 (1952) 296-311

- Rola Tradycji w powstaniu Pentateuchu. 1 (1952) 34-45

- Synaj - kraina Turkusów. 6 (1958) 523-528

- Teocentryczny charakter psalmów. 1 (1977) 27-37

- Urzędy Józefa biblijnego w świetle egiptologii. 3-4 (1961) 95-103

- YAHWEH Malak w psalmach o królowaniu Boga. 5 (1980) 238-247

- Znaczenie wyrażenia torah w Psałterzu. 4-5 (1975) 151-159

ŁACH Stanisław ks., STYŚ St. SJ, Polski komentarz do Starego Testamentu. 1 (1959) 98-101

ŁOPATKA Grzegorz ks., Seweryn Grabianka — świecki apostoł Biblii. W 30. rocznicę śmierci. 4 (1995) 260-270

ŁAŚ Józef SJ, Podział Credo mszalnego na wiersze i strofy. 4-5 (1967) 260-265

- Rytmika polskich śpiewów liturgicznych. 4-5 (1968) 266-283

— W sprawie tekstów Ordinarium Missae. 6 (1968) 364-368

— W sprawie kompozycji liturgicznych w języku polskim. 6 (1966) 371-376

ŁAŚ Józef SJ, ZIEMIAŃSKI Stanisław SJ, W sprawie współczesnej pieśni kościelnej. 5 (1981) 289-303

ŁUKOWSKI Stanisław ks., Gratias agens? Benedixit. 3 (1949) 168-171

MACHALSKI Franciszek, Na biblijnym Libanie. 5-6 (1950) 309-322

- Tradycje biblijne w Iranie. 3 (1951) 292-296

MACHARSKI Franciszek kard., Słowo wstępne do numeru specjalnego. spec. (1979) 3

MACHINEK Marian MSF, Kazanie na Górze. Profetyczna prowokacja czy program życiowy? 2 (1998) 87-101

MACHURA Marian, Muzyka liturgiczna w kościołach polskich po Vaticanum II. 1 (1986) 69-75

- Organy w służbie liturgii. 3 (1987) 257-261

MAGOTT Brunon ks., Msza święta wotywna o Matce Boskiej w soboty Roku Maryjnego. 1 (1954) 44-46

- Ordo Hebdomadae Sanctae Instauratus - Najnowsze rubryki z obrzędów odnowionego Wielkiego Tygodnia. 4-5 (1955) 239-250

- Wiadomości liturgiczne. 2-3 (1955) 155-165

MALEJ Witold CM., Arcybiskup Władysław Zaleski — patriarcha Antiochii, nieznany miłośnik Pisma świętego (1852-1925). 2 (1960) 173-175 
- Documenta mariologica. 5 (1959) 524-525

MALIŃSKI Mieczysław ks., Którzy jesteśmy Słowem Bożym. 6 (1969) 362-375

- O homiliach. 4-5 (1970) 212-218

- Sakramenty - prasytuacja chrześcijanina. 2-3 (1970) 139-146

MAŁACZYŃSKI Franciszek OSB, Aspekty liturgiczne listu Jana Pawła II ze szczególnym uwzględnieniem sytuacji polskiej. 5 (1980) 284-288

- Bizantyjskie i łacińskie wpływy na liturgię Bożego Grobu. 2-6 (1992) 9093

- Błogosławieństwa w Mszale Pawła VI. 4 (1979) 228-234

- Chrzest w odrodzonej liturgii Wielkiego Tygodnia. 1-2 (1968) 47-54

- Dni gregoriańskie zakonnic. 5 (1961) 266-267

- Duchowość diakona, prezbitera i biskupa w świetle obrzędów święceń. 4 (1983) 312-320

- IX Spotkanie sekretarzy Komisji Narodowych Europy do spraw Liturgii. 2 (1989) 147-149

- 25. rocznica powstania Papieskiego Instytutu Liturgicznego w Rzymie. 1 (1987) 70-71

- Funkcja wychowawcza liturgii. 4-5 (1968) 244-251

- Funkcje świątyni katolickiej w świetle teologii, liturgii i tradycji. 3 (1984) 208-216

- Geneza i charakter instrukcji S. K. O o muzyce sakralnej i liturgii. 1 (1959) 63-65

- Hymn państwa watykańskiego. 1 (1997) 48-50

— Jak powstał nowy lekcjonarz mszalny? 2 (1988) 178-184

- Komentarz do „Instructio pro sacerdote infirmo”. 3 (1962) 182-183

- Kronika ruchu liturgicznego. 1 (1958) 66-68; 2 (1958) 169-171; 3 (1958) 269-271; 2 (1960) 163-167; 3-4 (1960) 359-362; 5 (1960) 488-490

- List do ks. Kazimierza Panusia prezesa PTT w Krakowie po nadaniu dyplomu uznania i medalu Towarzystwa. 1 (1998) 72

— Liturgia w życiu i działaniu papieża Jana XXIII. 4 (1963) 162-163

— Liturgia Zmartwychwstania w świetle ankiety. 2 (1957) 114-124

- Modlitwy mszalne. 1 (1966) 57-58

- Msza Jana Pawła II na Błoniach krakowskich. 1 (1980) 29-35

- Mszał rzymski dla diecezji polskich. 1 (1987) 49-58

- Nowe księgi liturgiczne na Wielki Tydzień. 2 (1958) 172-173

- Nowe księgi liturgiczne w życiu Kościoła. 4 (1995) 274-285 
- Nowy etap w odrodzeniu liturgii. 6 (1960) 497-498

- Nowy rytuał dla Polski. 4 (1963) 211-219

- Nurt liturgiczny w adhortacji papieża Pawła VI o kulcie Najśw. Maryi Panny. 6 (1975) 252-258

- Obrzędy sakramentu małżeństwa w rozwoju historycznym. 1-2 (1961) 5357

- Obrzędy wtajemniczenia chrześcijan dorosłych. 1 (1973) 7-14

- Odnowa liturgii w Polsce po II Soborze Watykańskim. 4 (1976) 189-194

- Odnowiona liturgia ślubów zakonnych. 6 (1986) 482-490

- O nowy przekład litanii loretańskiej. 3 (1958) 239-247

- Perspektywy reformy liturgii. 6 (1961) 298-311

- Pierwszy Międzynarodowy Kongres Duszpasterstwa Liturgicznego w Asyżu. 2 (1957) 125-133

- Pierwszy Polski Kongres Muzyki Gregoriańskiej na Jasnej Górze (23-24 IX 1958). 6 (1958) 547-549

- Poprawiony tekst litanii loretańskiej. 5 (1961) 229-231

- Praca nad odnowa błogosławieństw w Polsce. 4 (1979) 234-239

- Reforma obrzędów chrztu dorosłych. 5 (1962) 296-298

- Reforma roku kościelnego i kalendarza. 1 (1970) 1-2

- Spotkanie przewodniczących Diecezjalnych Komisji do spraw Liturgii. 1 (1981) 72

- Spotkanie sekretarzy Narodowych Komisji Liturgicznych Krajów Europejskich w Lizbonie. 1 (1987) 68-70

— Szafarz błogosławieństw. 2 (1993) 57-64

— Szczyt i źródło Kościoła. 1 (1965) 14-20

— Śp. diakon Pius Naróg OSB. 5 (1959) 511-512

— Śp. opat Teodor Neve OSB. 4 (1963) 222-223

— Śp. o. Adrien Nocent OSB (1913-1996). 4 (1997) 308-309

— Śp. o. Jorge Pinell OSB (1921-1997). 2 (1998) 147-148

— Śp. ksiądz biskup Paweł Tadeusz Zakrzewski. 1 (1962) 54-55

— Tydzień liturgiczny w archidiecezji gnieźnieńskiej. 2 (1960) 168-169

- Tydzień liturgiczny w Warszawie. 2 (1960) 169-171

- Ustanowienie patronów Polski. 5 (1962) 313-314

— Wkład Pisma św. w odnowę liturgii. 6 (1958) 476-479

- Wychowanie alumna i kapłana przez liturgię. 2-3 (1963) 113-123 
- Wydawanie ksiąg liturgicznych w języku polskim. 4-5 (1985) 321-331

— Zbiór mszy o Najświętszej Maryi Pannie. 3 (1998) 204-208

MAŁECKI Zdzisław ks., Krytyka pogańskich bóstw u Deuteroizajasza (44, 9-20). 3 (1996) 149-154

- Struktura literacka prologu księgi Deuteroizajasza (Iz 40, 1-11). 1 (1996) $14-18$

MAŃSKI I. SDB, Kłopoty dyrygenta w jubileuszowym Roku Maryjnym. 1 (1957) 6872

MARGAŃSKI Bolesław ks., Formy pozasakramentalnego gładzenia grzechów w Kościołach Wschodnich. 2-3 (1976) 96-105

- Podstawy teologiczne odnowionego rytu pogrzebowego. 1-2 (1974) 6-14

MARKLOWSKI Konrad ks., Aforyzmy biblijne o życiu bogobojnym. 4 (1949) 240246

— „In Spiritu humilitatis”. 2 (1951) 162-170

— Pismo św. w twórczości Pawła Claudela. 6 (1955) 362-373

- Problem nieśmiertelności duszy w księdze Koheleta. 5-6 (1948) 350-351

- Trwałe wartości Starego Testamentu. 1-2 (1950) 110-122

— Ważniejsze odkrycia biblijne na przełomie pół wieku. 4-6 (1951) 385-402

- Wniebowzięcie Najśw. Maryi Panny w świetle Pisma św. 1-2 (1950) 154157

— Z zagadnień księgi Koheleta. 5-6 (1950) 294-309

MARTINI Carlo Maria kard., Jak wspólnie modlić się psalmem? 2 (1995) 116-120

Materiały publikowane gdzie indziej z XII Kongresu Biblistów. 4-5 (1975) 239

Materiały sesji in memoriam ks. Józefa Archutowskiego, ks. Jana Mazerskiego SDB i ks. Aleksego Klawka. 1 (1995) 33

MATRAS Tadeusz ks., „Aspekty natchnienia biblijnego”. Sprawozdanie z sympozjum we Włocławku. 2 (1981) 130-132

— XXVI Dni Biblijne w Louvain. 6 (1975) 277-279

— XXIII sympozjum biblistów polskich. 1 (1988) 84-88

— XXV sympozjum biblistów polskich (Katowice 16-17 IX 1986). 1 (1987) $74-77$

- XXVI sympozjum polskich biblistów (Łódź 13-14 września 1988 r.). 1 (1989) 65-67

— XXVII obrady sekcji biblistów polskich (Lublin 1989). 3-6 (1990) 157158 
- XXVIII spotkanie sekcji biblistów polskich (Warszawa 1990). 1-3 (1991) $70-72$

- XXIX sesja sekcji biblistów polskich (Siedlce-Nowe Opole 1991). 2-4 (1992) 99-101

- Kongres Biblistów Polskich w Lublinie (14-16 IX 1983). 5 (1984) 425426

— XV Kongres Biblistów Polskich. 6 (1977) 335-337

— XVI Kongres Biblistów Polskich. 1 (1979) 63-64

— „Słowo Boże w pierwotnym Kościele”. XVII sympozjum biblistów polskich w Nysie. 2 (1980) 106-108

— Sympozjum biblistów polskich (Tarnów 1986). 3 (1986) 280-284

- Szkice homilii na Adwent. 6 (1974) 344-354

— Śp. ks. bp Tadeusz Stanisław Szwagrzyk (1923-1992). 2 (1993) 104-106

- III Kongres Teologów Polskich. 1 (1977) 68-70

- XXXI spotkanie biblistów polskich (Ożarów Mazowiecki-Ołtarzew 1993). 2 (1994) 120-123

- XXXII sesja polskich biblistów (Częstochowa 1994). 3 (1995) 209-213

- XXXIV spotkanie biblistów polskich w Radomiu (1996). 2 (1997) 155158

- XXXV spotkanie biblistów polskich (Przemyśl 1997). 3 (1998) 228-234

- Wierny liturgii - Laudacja podczas odznaczenia o. dra Franciszka Małaczyńskiego OSB medalem pamiątkowym Polskiego Towarzystwa Teologicznego w Krakowie dnia 18 II 1997 r. 1 (1998) 70-71

MEISSNER Karol OSB, Godzina biblijna - Kapłaństwo. 3-4 (1961) 137-148

MENDECKI Norbert ks., Alalach — zapomniane królestwo. 1 (1996) 49-51

- Czy ossuaria z epigrafami rodziny Jezusa z Jerozolimy mogą być autentyczne? 2 (1997) 150-151

- Działalność Jana ben Zakaja i Gamaliela II w Jabne. 1 (1984) 65-68

- Dzieje Masady. Zarys historii badań archeologicznych. 3 (1987) 214-220; 3 (1996) 164-170

— Elefantyna - w setną rocznicę odkrycia. 1 (1993) 37-39

- Epigraf z Tell Siran. 1 (1998) 35-38

- Groby królewskie w Jerozolimie. 3-4 (1993) 188-189

- Jahwe budowniczy Jerozolimy zbiera rozproszonych. 1 (1983) 13-16

— Jak Dawid został królem? 3 (1997) 200-202

— Jak powstał Pięcioksiagg? 5 (1984) 427-428 
- Kaddisz. 4-5 (1985) 416-418

— Łódź z czasów Chrystusa nad jeziorem Genezaret. 6 (1986) 490-492

— Modlitwa „Alenu”. 3 (1988) 226-229

— Modlitwa „osiemnastu błogosławieństw”. 2 (1984) 140-143

- Najstarszy tekst Pisma świętego? 1 (1987) 66-68

- Napis w tunelu Siloe. 2 (1987) 142-143

- Napisy z Kuntillet (Agrud i Hirbet et Qom). 4 (1988) 337-339

- Nowe odkrycia archeologiczne w Sefforis. 6 (1987) 510-512

- Palestyna i Jerozolima w okresie przedizraelskim. 2 (1995) 81-94

- Prace archeologiczne w grotach Wadi Marabbaat i grotach pomiędzy Masadą a En-Gedi. 4 (1996) 230-235

- Srebrny cielec z Askalon. 1 (1992) 44

- Synagoga z Kafarnaum w świetle ostatnich badań. 2-6 (1992) 104-106

- Szekina w literaturze żydowskiej. Chrystus a szekina. 3 (1994) 159-162

- Sztuka Izraelitów. W stulecie narodzin archeologii Palestyny. 4-6 (1991) 99-103

- Świątynia Jahwe. Sensacyjne wykopaliska archeologiczne na wzgórzu Arad. 2 (1994) 103-106

— Tablice narodów w Rdz 10. 2 (1996) 104-107

- Ugarit (Ras Szamra) - historia wykopalisk w okresie półwiecza. 2 (1989) 111-114

- Ukrzyżowany mężczyzna z Giv’ at Ha-Mivtar. 1 (1997) 36-38

- Zarys historii Moabu. 4 (1994) 242-247

— Znaczenie odkrycia genizy kairskiej. 4 (1998) 270-275

MĘDALA Stanisław CM, Formy interpretacji Biblii w judaiźmie okresu międzytestamentalnego. 3 (1986) 212-231

- Nowe źródło do badań przekazu Ewangelii Mateusza. 4 (1989) 249-259

- Odkrycia świątyni izraelskiej z czasów Salomona. 4-5 (1968) 226-232

- Problem struktury literackiej czwartej Ewangelii. 1 (1993) 11-17

- Rola Biblii w kulturze światowej. 4-6 (1991) 90-99

- Sprawozdanie z działalności Polskiego Towarzystwa Teologicznego w Krakowie w roku 1977. 5 (1978) 266-269

- Sprawozdanie z działalności Polskiego Towarzystwa Teologicznego w Krakowie w roku 1978. 5 (1979) 281-284

- Sprawozdanie z działalności Polskiego Towarzystwa Teologicznego w Krakowie w roku 1979. 3 (1980) 174-177 
- Sprawozdanie z Międzynarodowego Kongresu Kumranologicznego w Groningen (1989). 3-6 (1990) 158-160

— Śp. ks. Jan Stępień (1910-1995). 2 (1995) 142-146

- Targumy do Pięcioksięgu w świetle najnowszych badań. 6 (1969) 319-327

- Tradycja o wieczności Mesjasza i redakcja J 12, 34. 4-5 (1975) 199-216

MIAZEK Jan ks., Odnowa liturgii jako problem organizacji życia religijnego i duszpasterstwa w diecezji. 4-5 (1985) 312-320

- Struktura nabożeństw eucharystycznych w praktyce parafialnej. 4 (1986) 317-324

MIAZGA Tadeusz ks., Co mówi konstytucja liturgiczna o muzyce. 6 (1965) 372-377

MICEWSKI Bolesław CR, Śp. ks. Feliks Szreder CR (1914-1989). 3-6 (1990) 166-168

MICHAŁEK Roman ks., Aspekt prawny odnowionej liturgii chrztu dzieci. 2 (1972) $108-117$

- Komentarz prawno-liturgiczny do drugiej Instrukcji o należytym wykonywaniu konstytucji „O liturgii”. 1-2 (1968) 97-104

- Nowe obrzędy pogrzebu i związane z nimi problemy prawno-liturgiczne. 1-2 (1974) 14-28

- Prawno-liturgiczne problemy Dyrektorium o mszach z udziałem dzieci. 23 (1977) 90-98

- Ważniejsze przepisy zawarte w Instrukcji św. Kongregacji Obrzędów o kulcie tajemnicy eucharystycznej z dnia 25 V 1967 r. 1-2 (1968) 108114

- Zadania Diecezjalnej Komisji do spraw Liturgii w świetle dokumentów Kościoła. 1 (1981) 60-71

- Zmiany obrzędowe wprowadzone przez Instrukcje do konstytucji o św. liturgii z dnia 26 IX 1964 r. 5 (1965) 280-292

MICKIEWICZ Franciszek SAC, Koncepcje świątyni w tekstach Wspólnoty z Qumran. 4 (1997) 250-266

— „Synu odpuszczają ci się grzechy twoje” (Mt 2, 1-12). 1 (1996) 28-38

MIKOŁAJCZAK Mieczysław ks., Samoofiarowanie Eliasza. (1 Krl 17, 21). 2 (1998) 81-87

- Znaczenie świątyni jerozolimskiej w Łk 1-2. 3 (1998) 181-186

MIKOŁAJCZYK Marian ks., Błogosławieństwa dziś i jutro. 4 (1977) 205-213

- Historia i rozwój błogosławieństw w liturgii Kościoła katolickiego. 2-3 (1976) 162-171

MILEWSKI Tadeusz, Odpowiedź ks. Jakubcowi. 4 (1951) 352-353

MILIK Józef ks., Papieski Instytut Biblijny (1909-1949). 5 (1949) 318-329 
MISINIEC Stefan ks., Papież na Wawelu. 1 (1980) 20-25

MISIUREK Jerzy ks., Emanus. 5 (1978) 240-246

- Ks. Jakub Wujek jako obrońca synostwa Bożego Chrystusa. 5 (1983) 392400

MISTECKA Lucyna CR, Biblijne wizje człowieka. 5-6 (1976) 300-304

MŁOTEK Antoni ks., Pismo święte w życiu pierwotnych chrześcijan. 6 (1977) 310323

MODZELEWSKI Zenon SAC, Trzy thumaczenia Psalmu 137. 2 (1962) 119-128

MOLE Marian, O mapach ze Wschodu. 6 (1949) 441-446

MOŃKA Zenon ks., Znaczenie religijne ołtarza u Izraelitów. 4-5 (1965) 199-206

Moralność wynika z Misterium. Wnioski z obrad nad małżeństwem Francuskiego Ośrodka Duszpasterstwa Liturgicznego w Wersalu 1956 r. (przekład OSB — Tyniec). 1-2 (1961) 68-71

MOYSA Stefan SJ, Problem zbawienia niekatolików. 3-4 (1960) 287-302

MROWIEC Karol CM., Drugie sprawozdanie z prac zespołu redakcyjnego dla opracowania ogólnopolskiego śpiewnika kościelnego. 6 (1983) 535-549

- Kompozycje mszalne w języku polskim. 3 (1966) 203-206

- Kryteria oceny pieśni kościelnych. 3 (1978) 147-151

- Liturgiczne śpiewy na uroczystość Niepokalanego Poczęcia NMP (8 grudnia). 3-6 (1954) 210-215

- Realizacja postanowień konstytucji „De sacra liturgia” w odniesieniu do muzyki kościelnej we Francji i w Niemczech. 6 (1965) 377-379

- XVII Krajowy Kongres Muzyki Kościelnej we Włoszech. 2 (1960) 171173

- Słowo wstępne thumacza. 6 (1955) 328-334

- Wychowawcza rola chorału gregoriańskiego w życiu młodzieży duchownej. 5 (1961) 242-251

— Z problematyki polskiej pieśni kościelnej. 3 (1959) 296-309

MUCHOWSKI Piotr, Język hebrajski qumrański, jego zasięg i status społeczny. 3 (1998) 161-168

MUSZYŃSKA Krystyna, Najstarszy kodeks Nowego Testamentu w Polsce. 5 (1986) 492-493

MUSZYŃSKI Henryk ks., IX Międzynarodowy Kongres Biblistów Starego Testamentu. 6 (1977) 331-334

- Trudności i postulaty aktualnego ujęcia problemu natchnienia biblijnego. 1 (1979) 52-56 
MYCIELSKI Ludwik OSB, Archeologia Palestyny Albrighta w wersji polskiej (1964). 6 (1987) 512-514

- Jedność samych Apostołów - podstawowy i nieodzowny warunek owocnego apostolstwa. 4 (1987) 354-359

- Modlitwy Ostatniej Wieczerzy i ich wpływ na powstanie modlitw eucharystycznych Kościoła. 6 (1968) 345-351

- Przypowieść o pojednaniu. Biblijne wprowadzenie do adhortacji apostolskiej Jana Pawła II „Reconciliatio et paenitentia”. 2 (1986) 135-155

MYSZOR Wincenty ks., Apokalipsa Pawła. 1 (1972) 22-29

MYSZYNIEWSKI Józef SJ, Radość w psalmach. 1 (1984) 84-93

NADOLSKI Bogusław TChr, Apologie w celebracji eucharystycznej jako pozasakramentalne formy pokuty. 2-3 (1976) 86-96

- Celebracja Chrystusa obecnego w Najświętszym Sakramencie. 4 (1986) 347-352

- Drugie wydanie typiczne obrzędów święceń (1989). 2-6 (1992) 93-98

- Elementy wychowania eucharystycznego. 2 (1986) 127-133

— In memoriam A. J. Jungmanna (1889-1975). 6 (1975) 285-286

— „Ja jestem z wami”. Uwielbiony Chrystus w Najświętszym Sakramencie. 4 (1986) 298-305

— In memoriam Dom Bernard Botta († 1980). 5 (1981) 311-312

— Kontynuacja Mszy św. w życiu. 4-5 (1969) 262-266

- Ks. Marius Righetti (1882-1975). 5-6 (1976) 312-313

- Liturgia jako proces komunikacji. 3 (1989) 161-168

- Msze tematyczne. 5 (1977) 269-273

- Niedziela sakramentem Paschy. 5 (1988) 407-415

— Niektóre próby horyzontalizmu w liturgii. 4 (1981) 233-240

- Obrzęd pogrzebu wiernego świeckiego w okresie paschalnym w liturgii bizantyjskiej. 3-4 (1993 (183-187

— 50-lecie „Bibel und Liturgie”. 4 (1977) 216

- Przygotowanie darów ofiarnych — wspólnotą miłości braterskiej. 3 (1966) 182-188

- Realizacja konstytucji o liturgii w Kościele powszechnym. Stan faktyczny i perspektywy. 4-5 (1985) 286-290

- Recepcja konstytucji „Sacrosanctum Concilium” w Polsce. 1 (1986) 1520

_ Sakramentalia w Kościołach protestanckich. 2 (1993) 72-78 
- Spotkania liturgiczne 1972. 1 (1973) 49-52

- Sympozjum liturgiczne w Seggan. 3 (1975) 137-138

- Wewnętrzna struktura liturgii. 6 (1967) 361-365; 3 (1968) 168-179

- Wieniec adwentowy. 4-6 (1991) 141-146

- Wpływ świętowania na kulturę. 5 (1984) 401-410

- Wymowa obrzędów przygotowania darów. 4 (1973) 205-209

— Zasady odnowy błogosławieństw. 4 (1979) 222-228

NADROWSKI Henryk MIC, Ołtarz - jego charakter koncentrujący i funkcjonalny. 6 (1972) 316-329

— Wychowawcza funkcja sztuki religijnej i sakralnej. 4 (1973) 194-200

NAGÓRNY Janusz ks., Obrzędy pokuty i odnowienia przymierza w Starym Testamencie. 6 (1984) 476-483

- Wierność Bogu jako gwarancja przebaczenia i trwałości przymierza w Starym Testamencie. 1 (1983) 9-12

NAKONIECZNY Rafał, Współczesny geniusz apostołem Biblii. Sylwetka Alberta Schweitzera. 2 (1998) 138-141

NANOWSKI Janusz ks., Nabożeństwo Słowa Bożego szkołą czynnego i owocnego uczestnictwa w liturgii sakramentów. 3 (1985) 213-221

- Teologiczna treść nabożeństw uświęcenia czasu w obrządku bizantyjskosłowiańskim. 6 (1978) 297-309

NAPIERAŁA Stanisław ks., Communicatio in sacris w posoborowych dokumentach Kościoła. 5-6 (1973) 307-318

- Prawosławna koncepcja liturgii. 2-3 (1971) 151-155

NARECKI Zbigniew, Odnowiona Liturgia godzin w służbie ewangelizacji parafialnej. 5 (1987) 420-437

NARÓG Pius OSB, Kronika liturgiczna. 4 (1958) 343-346; 5 (1958) 457-461; 1 (1959) 102-107; 3 (1959) 317-319

— „Przez Biblię do liturgii”. 6 (1958) 541-546

— Stosunek papieża Jana XXIII do ruchu liturgicznego. 5 (1959) 513-514

NAUCZYK Antoni CM, Niedawno odkryte manuskrypty znad Morza Martwego w nowym świetle. 1 (1953) 201-207

- Ogólna reforma liturgiczna. 5-6 (1950) 365-373

- Reforma liturgiczna. 5-6 (1952) 480-487

NEUNHEUSER Burkhard OSB, Problem obecności MISTERIUM w liturgii w dziełach O. Casela. 2 (1988) 129-135 
- Sto lat ruchu odnowy liturgicznej zapoczątkowanego przez o. Prospera Gueranger. Przeszłość i perspektywy. 4 (1976) 195-207

NIR Roman ks., Rękopisy liturgiczne biblioteki PP. Norbertanek w Imbramowicach. 1 (1976) 47-53

NORTH Robert SJ, Rozwój archeologiczno-egzegetyczny na przestrzeni ostatnich 25 lat. 2-3 (1973) 57-67

NOSSOL Alfons bp, Choć umarł żyje! Homilia wygłoszona podczas Mszy św. pogrzebowej ks. prof. W. Schenka. 6 (1983) 474-483

NOWAK Stanisław ks., Duchowość eucharystyczna kapłanów i kandydatów do kapłaństwa. 3 (1975) 113-124

- Duchowość kapłaństwa w świetle pism kardynała Karola Wojtyły. spec. (1979) 26-31

- Duchowość odkupienia środkiem odnowy Kościoła według encykliki „Redemptor hominis”. 6 (1979) 347-357

- Kierownictwo duchowe sakramentalne. 6 (1984) 511-524

- Modlitwa różańcowa w adhortacji Pawła VI „Marialis cultus”. 4-5 (1974) 271-275

NOWAK Władysław ks., Elementy agendy Marcina Kromera w odnowionej liturgii sakramentu małżeństwa dostosowany do zwyczajów diecezji polskich. 2-3 (1979) 149-156

- Epikletyczny gest koncelebransów przy słowach konsekracji. 6 (1985) 399-405

- VI Międzynarodowe sympozjum józefologiczne w Rzymie (1993). 1 (1994) 53-56

- VII Międzynarodowe sympozjum józefologiczne na Malcie (1997). 2 (1998) 141-146

- Tradycja świętowania niedzieli we wspólnocie Kościoła luterańskoewangelickiego. 2 (1995) 106-116

NOWAKOWSKI Henryk ks., Znaczenie i sens mesjański kuszenia Chrystusa. 1 (1952) 45-53

NOWAKOWSKI Przemysław CM, XXXIV seminarium wykładowców liturgiki (Radom 1998). 4 (1998) 307-311

OBERTYŃSKI Zdzisław ks., Benedictio propitiatorii w Krakowie. 1-2 (1968) 69-77

- Kościół i jego wnętrze. 4 (1949) 279-293; 5 (1949) 335-370

- Święta Monegundis. 6 (1966) 353-362

OBRĄCZKA Piotr, Ksiądz profesor Wacław Schenk w dniu swoim powszednim. 6 (1983) 493-499 
OBTUŁOWICZ Czesław ks., Błogosławiony Jakub Strepa, franciszkanin, arcybiskup lwowski (1409-1459). 5 (1959) 526-527

O. dr Franciszek Stanisław Małaczyński OSB (W 70-lecie urodzin). 1-2 (1990) 1-2

ODZIMEK Adam ks., Łukaszowy kerygmat o Jezusie męczenniku. 2 (1980) 68-79

Ogólne wprowadzenie do mszału rzymskiego. 1 (1971) 1-79

OGRODZKI Jan, Prorocka posługa Kościoła w świetle biblijnej koncepcji Słowa Bożego. 2 (1989) 132-139

OLEŚ Marian ks., Maryjne znaczenie słów Łk 2, 35 w patrologii od początku aż do VIII wieku. 1 (1964) 4-19

- Milczenie Ewangelii o Matce Bożej. 1 (1962) 44-49

OLSZAŃSKI Tadeusz CM, Homilia na pierwszą i trzecią niedzielę Adwentu. 4-5 (1970) 218-225

- Homilia na trzecią niedzielę po Objawieniu. 6 (1968) 374-376

- Homilia na niedzielę Sześćdziesiątnicy. 6 (1968) 377-379

- Homilia na czwartą, siódmą, dziewiątą i jedenastą niedzielę po Zesłaniu Ducha Świętego. 2-3 (1969) 145-158

van OOST Karol OSB, O. Kolumba Marmion i liturgia. 3 (1948) 175-185

ORAWA Zofia, Królewskość Najświętszej Maryi Panny w nauczaniu Kościoła. 5 (1961) 221-229

ORDON Hubert SDS, Odznaczenie ks. prof. Feliksa Gryglewicza (w osiemdziesi ęciolecie urodzin). 3-6 (1990) 162-164

— Śp. ks. prof. Feliks Gryglewicz (1909-1991). 1 (1993) $42-45$

PACIUSZKIEWICZ Mirosław SJ, Dzieje kultu św. Andrzeja Boboli. 5-6 (1989) 378391

PADACZ Władysław ks., Kapłan wyjaśniający modlitwy i czynności liturgiczne. 3-4 (1960) 341-346

- Organiści w świetle instrukcji o śpiewie i muzyce kościelnej. 3-4 (1961) 152-157

- Śpiew i muzyka kościelna w świetle statutów powojennych synodów diecezjalnych. 6 (1958) 498-506

PADO Włodzimierz Maria OFMConv, Czy Kochanowski laicyzował psalmy? 1 (1986) $33-41$

PAETZ Juliusz bp, Pismo święte — nasz chleb powszedni. 1 (1993) 18-21

PANUŚ Kazimierz ks., Sprawozdanie prezesa Polskiego Towarzystwa Teologicznego w Krakowie za rok 1996. 4 (1997) 287-292

- Sprawozdanie prezesa Polskiego Towarzystwa Teologicznego w Krakowie za rok 1997. 3 (1998) 222-227 
PAROL Ryszard OFMConv, Kongres „Musica sacra” w Rzymie (1989). 4-6 (1991) 149-150

PASIERB Janusz Stanisław ks., A. Mickiewicz o języku sakralnym. 1 (1958) 43-49

PAŚCIAK Józef OP, Biblijny obraz Chrystusa Króla. 3 (1972) 168-189

PAWEŁ VI, Do biblistów włoskich. 6 (1968) 380-382

- Teologia a Magisterium Ecclesiae (z przemówienia 1.10.1966). 4-5 (1966) 209-215

— Z modlitwy nad Grobem Chrystusa. 6 (1964) 364

— Z przemówienia na audiencji ogólnej 17 maja 1972 r. 2 (1972) 196

- Z przemówienia przy Grobie Chrystusa w Jerozolimie. 6 (1964) 333

PAWLAK Ireneusz ks., Alleluja z wersetem w liturgii mszalnej. 5 (1977) 245-253

- Obrady muzyków kościelnych (Gdańsk-Oliwa 1993). 1 (1994) 58-59

- Omówienie instrukcji Episkopatu Polski o muzyce liturgicznej po Soborze Watykańskim II. 3 (1981) 149-155

- Program nauczania muzyki kościelnej w seminariach duchownych w Polsce. 4-5 (1972) 257-264

— Sekwencje w liturgii mszalnej po Soborze Watykańskim II. 4 (1994) 262267

— Seminarium naukowe Sekcji Muzyki Kościelnej (1977). 3 (1977) 257-264

- Sympozjum naukowe muzyków kościelnych. 1 (1981) 77-80

- Śpiew i muzyka w obrzędach chrztu dzieci. 2 (1972) 117-125

- Śpiewy ordinarium Missae w świetle odnowy liturgicznej. 3 (1967) 161168

— Z zagadnień terminologii dotyczącej muzyki związanej z kultem. 1 (1983) 26-33

PAWŁOWICZ Zygmunt ks., Medytacja podczas godziny biblijnej „Chrystus chlebem życia". 2 (1983) 154-160

PAZERA Wojciech ks., Apostolat biblijny jako realizacja zobowiązań Roku Jubileuszowego. 3 (1985) 242-248

— Bojaźń Boża jako kult religijny w księdze Koheleta. 4 (1988) 307-313

- Zmartwychwstanie jako przedmiot wiary i fakt historyczny (materiały do konferencji). 3 (1984) 256-271

PEŁCZYŃSKI Grzegorz, Teologia pokoju w tekstach Proto-Izajasza. 3 (1994) 183188

PETER Michał ks., Biblia w liturgii. 3 (1952) 273-275

- Dookoła problemu Jerycha. 5 (1961) 198-205 
- Epoka proroka Aggeusza. 5 (1964) 275-280

- Epoka proroka Malachiasza. 4-5 (1955) 184-194

- Istota natchnienia biblijnego $\mathrm{w}$ dyskusji ostatniego dziesięciolecia. 6 (1961) 273-284

— Lekcja we Mszy św. „Rorate coeli” (Iz 7, 10-15). 5-6 (1952) 400-423

— Na marginesie „Podróży naukowej do Ziemi Świętej”. 3-4 (1961) 133-137

- Nauka Soboru Watykańskiego II o Piśmie świętym. 6 (1967) 321-331

— Pismo święte w życiu Ludu Bożego. 2-3 (1969) 85-94

- Podróż naukowa Papieskiego Instytutu Biblijnego (lipiec-sierpień 1959 r.). 1 (1963) 48-54

- Proroctwo Malachiasza o ofierze czystej $(1,11)$. 1-3 (1956) 121-128

- Psałterz według wersji Jana z Czarnolasu. 5 (1981) 257-262

- Rzeczywistość historyczna w Rdz 14. 1 (1976) 10-19

- VII Kongres Międzynarodowej Organizacji do Studiów nad Starym Testamentem (Uppsala, 8-12 VIII 1971). 1 (1972) 36-45

- Szema' Izrael (Pwt 6, 4). Tekst monoteistyczny. 1 (1979) 22-34

— Zabytkowy kielich w Poznaniu. 2 (1957) 134

PETRANI Aleksy ks., Hoc enim et Crates fecit philosophus. 1 (1957) 66-68

PIĄTEK Stanisław ks., Daniel i jego proroctwo. 2-3 (1973) 150-153

- Dzwony w liturgii Kościoła. 4-5 (1968) 311-315

- Na drodze odnowienia dyscypliny sakramentu pokuty. 6 (1974) 339-340

- Naglące problemy z zakresu praktyki spowiadania. 4 (1964) 252-254

PIECH Stanisław ks., Dysertacje o tematyce biblijnej i liturgicznej na Wydziale Teol ogicznym Uniwersytetu Jagiellońskiego w latach 1945-1954. 4 (1997) 266-276

- Ks. Józefa Archutowskiego umiłowanie Pisma świętego. 1 (1995) 39-45

PIELATOWSKI Kazimierz ks., Jak udostępnić ludziom udział w liturgii sakramentów świętych? 2 (1951) 218-230

PIERONEK Tadeusz ks., Duszpasterski synod archidiecezji krakowskiej. spec. (1979) $16-25$

- Teksty kościelnego prawa powszechnego odnoszące się do liturgii. 2 (1978) 88-94

PIERÓG Andrzej, Papieska koronacja obrazu Matki Bożej z Makowa. 1 (1980) 36-38

PIETRZYK Antoni MSF, Seminarium naukowe poświęcone muzyce w katedrach polskich. 2 (1986) 134-135

PILCH John, Poczucie humoru w Biblii. 4 (1996) 255-261

PILCHOWA Wanda, Do Ojca św. Jana Pawła II. spec. (1979) 54 
PINDEL Roman ks., O model rozwoju idei Ciała Chrystusa u świętego Pawła. 3 (1994) 188-196

PISAREK Stanisław ks., Biblijny tryptyk Juliana Stryjkowskiego. 4 (1988) 361-365

- 46 zjazd Studiorum Novi Testamenti Societatis (1991). 4-6 (1991) 146147

— IX Colloqium Biblicum (Wiedeń 1996). 4 (1996) 269-271

- Historia oddziaływania tekstu (Wirkungsgeschichte) jako nowa metoda badania Nowego Testamentu. 2 (1986) 96-107

- Hypomone w 1. Liście do Tesaloniczan (1, 3). 3 (1985) 200-207

- Laudacja z okazji nadania ks. profesorowi Stanisławowi Grzybkowi medalu bene merenti przez PAT w Krakowie, dnia 20 X 1997 r. 1 (1998) 6669

- Nowa ewangelizacja z Gniezna (przegląd). 1 (1997) 78-80

- 53. Kongres SNTS (Kopenhaga 1998). 4 (1998) 297-300

- Przegląd nowych atlasów biblijnych. 4 (1989) 309-313

— Symposium Moldavianum (1989). 4 (1998) 300-304

PISARZAK Marian MIC, Aspekt paschalno-eschatologiczny liturgii zmarłych. 4-5 (1972) 252-256

- Błogosławieństwo pokarmów i napojów wielkanocnych. 2 (1993) 93-103

— „Christus annus est”. 6 (1969) 376-378

- Dyskusja nad referatami. 1-2 (1974) 73-75

- Przygotowanie Eucharystii niedzielnej. 1 (1981) 25-31

- Teologia modlitwy za zmarłych według rytuału „Obrzędy pogrzebu”. 3 (1980) 127-144

— Udział służby liturgicznej w sakramencie chrztu świętego. 2 (1972) 134137

- Udział wiernych w przygotowaniu i sprawowaniu niedzielnej Euchary stii. 3 (1994) 204-211

- Zmiana pojęć w liturgii błogosławieństw. 4 (1979) 205-222

- Zmiany w obchodzie świąt maryjnych. 6 (1972) 356-358

PISARZAK Marian MIC, KRAKOWIAK Czesław ks., Dyskusja nad referatami. 1-2 (1974) 73-75

PISKOREK Julian SJ. Polski projekt reformy kalendarza na Soborze Watykańskim II. 3 (1964) 175-188

PŁACZEK Franciszek ks., Problematyka archeologii starochrześcijańskiej i palestyńskiej w pracach Polskiego Towarzystwa Teologicznego (1922-1939). 1 (1985) 2834 
POCIEJ Bogdan, Muzyka w kościele — problem wartości. 3 (1978) 141-147

PODLEŚ Antoni ks., Pontyfikał płocki z XII wieku. 6 (1981) 372-377

— Pontyfikał płocki z XIII wieku. 4 (1978) 215-216

Pokuta (Wnioski sesji Francuskiego Ośrodka Duszpasterstwa Liturgicznego w Wersalu w dniach 3-5 września 1958 roku — przekład o. Dominik Michałowski OSB). 3 (1962) 174-180

POŁUBICKI Władysław SVD, Pismo św. w katechezie misyjnej. 4 (1965) 236-240

PONIŻY Bogdan ks., Manna biblijna zapowiedzią Eucharystii. 2 (1996) 73-85

- Opowiadanie o wężu - znaku ocalenia (Lb 21, 4-9) w świetle tradycji biblijnych. 1 (1988) 14-25

- Poznanie Boga na podstawie Mdr 13, 1-9. 2 (1981) 97-105

- Wielka alegoria patriarchów w Mdr 10, 1-14. 3 (1994) 145-159

POPIEL Jan SJ, Sakralny wyraz dawnych i współczesnych form architektury sakralnej. 3 (1984) 225-229

POŚPIECH Remigiusz, Zjazd członków sekcji wykładowców muzyki kościelnej w Polsce (1987). 5 (1988) 447-448

— Zjazd członków sekcji wykładowców muzyki kościelnej w Polsce (1989). 1-3 (1991) 75-76

POTOCKI Stanisław ks., Misterium Paschy Starego Testamentu. 4 (1988) 274-286

- Układ literacki nauk mędrców anonimowych z księgi Przysłów (22, 1724, 22). 2 (1985) 111-124

— Z historii mędrców Izraela. 4-5 (1970) 180-198

Powstanie Towarzystwa Biblijnego w Polsce. 1 (1993) 39-40

PROKOP Krzysztof Rafał, Uroczystość wręczenia ksiąg pamiątkowych ks. prof. Bolesławowi Przybyszewskiemu i o. dr. Pawłowi Sczanieckiemu OSB (Tyniec, 30 maja 1998). 3 (1998) 236-237

PROKULSKI Walenty SJ, Hellenizm św. Pawła. 1 (1953) 25-50

- Niewyczerpane bogactwa Chrystusowe. 3 (1948) 134-144

- O zasadę kolegialności episkopatu w Kościele. 2 (1964) 88-95

— Św. Piotr - apostoł Chrystusa. 3 (1965) 129-142

— Widzenie św. Pawła pod Damaszkiem. 1 (1963) 17-25

PRZECZEWSKI Marek OFMCap, Błogosławieństwo chrzcielnicy. 2 (1993) 85-93

PRZYBYLSKI Bernard OP, Aktualne zagadnienia eklezjologii. 4 (1959) 407-425

— Linie rozwojowe teologii polskiej. 2 (1966) 82-99

— Pozycja Matki Bożej w Kościele. 1 (1960) 47-62

— Stan wiedzy mariologicznej z końcem 1960 roku. 5 (1961) 209-220 
- Współczesne zagadnienia w mariologii. 1 (1959) 29-51

PRZYBYLSKI Tadeusz SDB, Ks. dr Jan Mazerski SDB (1901-1944) biblista-muzyk. 1 (1995) 44-52

PRZYBYSZEWSKI Bolesław ks., Życiorys św. Stanisława — biskupa krakowskiego i męczennika. spec. (1979) 55-79

PYTEL Jan Kanty ks., Człowiek jako świątynia w nauce Nowego Testamentu. 6 (1962) 337-343

- IV grota w Qumran. 2-3 (1973) 85-93

- Nowotestamentowa terminologia gościnności. 3 (1981) 162-165

— Pojęcie gościnności w literaturze biblijnej i greckiej. 4 (1977) 172-181

— Symbolika ognia w Piśmie św. 2 (1989) 115-119

R. R., Poszukiwania na górze Ararat. 5-6 (1952) 487

RAFIŃSKI Grzegorz ks., Metoda retoryczna we współczesnej biblistyce. 3-4 (1993) 135-148

- Problem struktury 1 Kor 1-4. 2 (1994) 73-81

- Z problematyki genezy pism z Qumran (W 40. rocznicę pierwszych odkryć). 6 (1987) 465-476

RAK Romuald ks., Dawne i nowe śpiewy pogrzebowe na Śląsku. 1-2 (1974) 65-73

— Idea przewodnia liturgii Kościoła. 4 (1963) 167-173

- Kult Serca Pana Jezusa. 3 (1975) 125-135

- Kult św. Liboriusza biskupa w Paderborn (Sprawozdanie z uroczystości w 1988). 2 (1989) 142-146

— „Miedź dźwięcząca i cymbał brzmiący”. 4-6 (1951) 411-417

- Muzyka beatowa w kościele. 4-5 (1969) 249-262

- Muzyka kościelna w Polsce w aspekcie socjologicznym. 3 (1978) 129-141

— Nieszpory niedzielne. 1 (1961) 34-43

- Pius Parsch (1884-1954). 3 (1966) 188-198

— Polski śpiew „Credo” we Mszy świętej. 2 (1967) 110-112

- Rozdzielanie Komunii św. infra Missam. 6 (1962) 379-380

— Śpiew gregoriański a przeżycie liturgiczne (artykuł dyskusyjny). 6 (1958) $550-552$

— Śpiew ludowy na Mszy śpiewanej (artykuł dyskusyjny). 5 (1959) 515-516

- Teologiczne podstawy kultu Eucharystii w świetle dokumentów posoborowych. 4 (1986) 285-298

- Wigilia wielkanocna w diecezji katowickiej. 4 (1958) 350-353 
RAK Romuald ks., DWORNIK Roman., JAKAC Józef, W sprawie recenzji „Chorału do modlitewników śląskich". 4-5 (1968) 299-306

RAKOCY Waldemar CM, Metoda narracyjna w interpretacji tekstu biblijnego. 3 (1995) 161-168

- Retoryczny schemat argumentacji w 1 Kor 1-4. 4 (1995) 231-242

RAPPE Axel, BERGMAN Carl Göras, Tradycja i odnowa w pomieszczeniu kościelnym. 6 (1981) 377-387

RECHOWICZ Marian ks., Chrzest Polski a katolicka teologia misyjna we wcze śniejszym średniowieczu. 2 (1966) 67-74

— List kondolencyjny po śmierci ks. prof. W. Smereki. 2 (1984) 98-99

- Pionier ruchu liturgicznego. 4 (1948) 213-217

- Wpływ korektoriów paryskich na tematy skrypturystyczne stosowane w warsztacie naukowym mistrza Benedykta Hesse. 4-6 (1956) 289-294

RECZEK Józef, Gnostycy z Naq Hammadi. 2 (1983) 137-143

- Polskie wierszowane przekłady Pisma świętego. 4-5 (1968) 237-244

REDAKCJA, Ad multos annos (ks. A. Klawek). 1 (1963) 8-16

- Ad multos faustosque annos (abpowi K. Wojtyle). 1 (1964) 1-3

- Czasopisma liturgiczne. 6 (1967) 374-377

— Dziesiąty Tydzień Biblijny. 3 (1949) 212-215

- Głosy Wschodu o katolickich dogmatach maryjnych. 1 (1951) 125-126

— Grób Matki Bożej w Jerozolimie. 1 (1951) 122

- Kongres muzyki kościelnej. 1 (1964) 52

- Kurs biblijny w Lozannie. 1 (1964) 52

- Kurs duszpastersko-liturgiczny w Lublinie. 3 (1949) 218-219

- Liturgia Słowa Bożego. 1 (1965) 45-48

- Materiały IV sympozjum liturgiczno-pastoralnego na temat odnowionej liturgii pogrzebu. 1-2 (1973) 5-6

- Nekrolog papieża Jana Pawła I. 1-6 (1978) 281

- Nowa Palestyna a proroctwa biblijne. 3-4 (1950) 249

- Nowa Wulgata. 6 (1967) 374

— Nowe nominacje. 4 (1949) 302

- Nowe władze Polskiego Towarzystwa Teologicznego w Krakowie. 5 (1962) 314-315

- Nowy biskup pomocniczy diecezji częstochowskiej. 1 (1965) 44-45

- O. Augustyn Jankowski OSB członkiem Papieskiej Komisji Biblijnej. 6 (1978) 338 
- Obchody 500. rocznicy śmierci św. Jana Kantego. 5-6 (1973) 328-329

- Odkrycia nad Morzem Martwym. 6 (1957) 357

- Odszedł po wieczną nagrodę - Paweł VI. 5 (1978) 229

- Ormiańscy tłumacze Pisma św. 5 (1964) 324-325

- Państwo Izrael. 4 (1949) 303-304

— 50 lat pracy piórem (ks. H. Weryński). 5 (1964) 323-324

- Pierwszy Polak konsultorem Papieskiej Komisji Biblijnej. 5 (1965) 306307

— Pieśni na godziny biblijne. 1 (1964) 53

- Powstanie Godzinek o Matce Bożej. 2 (1952) 177-179

- Przed Międzynarodowym Kongresem Liturgicznym. 1 (1964) 52

- Refleksje o Ziemi Świętej. 2 (1951) 233-326

- Rok 1972 - Rokiem Biblii. 1 (1972) 47

- Sprawozdanie z działalności Polskiego Towarzystwa Teologicznego w Krakowie. 2 (1965) 105-106

- Sprawozdanie z posiedzeń Polskiego Towarzystwa Teologicznego (Sekcja biblijno-liturgiczna). 2 (1965) 106-107

- Studia biblijne w Polsce. 3 (1949) 215-216

— Sympozjum „Biblia i Liturgia”. 2-3 (1971) 81-82

- Sympozjum na temat chrztu w okresie patrystycznym. 6 (1974) 342-343

- Teologia nauką o Bogu. 1 (1977) 1-2

- Uroczyste posiedzenie Polskiego Towarzystwa Teologicznego. 3 (1962) 187

- Wprowadzenie do publikacji materiałów $\mathrm{z}$ sympozjum milenijnego. 2 (1966) 65

- Wprowadzenie do publikowanej konstytucji „Dei Verbum” (Drugi Sobór Watykański). 1 (1966) 1

- Wspólna Biblia w Afryce. 1 (1964) 53

— Wyjaśnienie w sprawie „mszału” benedyktyńskiego. 1 (1957) 72

- Zatwierdzenie mszalika. 3 (1949) 219

- Zebranie Polskiego Towarzystwa Teologicznego w Krakowie. 6 (1962) 383-384

— Złoty jubileusz kapłaństwa ks. prof. dra Józefa Jelity. 5 (1964) 316-318

— Życiorys ks. biskupa Andrzeja Wronki. 4 (1973) 170-173

REISER Marius, Poznaj sam siebie! Samopoznanie w starożytności i w chrześcijaństwie. 1 (1993) 1-11 
RENATA Maria s., Ego sum Pastor bonus. 3 (1948) 130-134

RĘKAS M[ichał] ks., Kościół w Liście do Efezjan. 6 (1949) 451-453

- O nasz udział w liturgii świętej. 5-6 (1948) 352-354

RODZIŃSKI Stanisław, Biblia w oczach dzieci. 6 (1975) 270-271

ROJEWSKI Andrzej ks., Postawy i gesty celebransa w eucharystycznym zgromadzeniu liturgicznym. 3 (1989) 198-207

- Sprawozdanie z XXII sympozjum liturgistów polskich (Przemyśl 1986). 5 (1987) 445-450

- Sprawozdanie z XXIV spotkania naukowego wykładowców liturgiki w Polsce (Katowice, 12-13 września 1988). 3 (1989) 238-240

- Sprawozdanie z XXIII sympozjum wykładowców liturgiki (Kraków 1987). 5 (1988) 440-442

- Współczesne zagrożenia niedzieli w niemieckojęzycznych publikacjach teologiczno-pastoralnych. 4 (1994) 268-280

ROMANEK Michał OP, Sympozjum „Biblia a kultura Europy” (Łódź 1992). 2-6 (1992) 103-104

ROMANIUK Kazimierz ks., Adresaci i cel Listu św. Pawła do Rzymian. 2-3 (1973) $111-117$

— „A na ziemi pokój ludziom Jego upodobania” (Łk 2, 14). 2 (1989) 81-85

- „Ciało i krew nie objawiły tobie, tylko Ojciec mój, który jest w niebiesiech" (Mt 16, 17). 6 (1964) 346-354

- Czy i jak rozumiał Jezus cel swojej własnej śmierci? 4 (1978) 198-206

— Ga 2, 20 w soteriologii św. Pawła. 2 (1962) 73-82

— „Gdyż nie był to czas na figi” (Mk 11, 12-14; Mt 21, 18-19). 3 (1974) 156-161

- Hermeneutyka biblijna a teologia liturgii. 2-3 (1971) 123-130

— „Każe go ćwiartować” (Łk 12, 46 par. Mt 24, 51). 5 (1987) 413-416

— „Łamanie chleba”. 1 (1987) 1-7

— "Perfecta caritas foras mitit timorem" (1 J 4, 17-18). 2-3 (1963) 80-87

— „Przyjacielu, jakżeś tu wszedł nie mając szaty godowej” (Mt 22, 1-14). 45 (1969) 267-276

- Pseudepigrafy nowotestamentalne. 3 (1983) 193-205

- Sprawiedliwość i miłość jako przymioty Boże. 1 (1964) 19-24

— XXXV Zjazd Studiów NT (Toronto 1980). 6 (1980) 356-358

- XXXIII Międzynarodowy Kongres Towarzystwa Studiów Nowotestamentalnych (Studiorum Novi Testamenti Societas). 6 (1978) 330-332 
- 36. Zjazd Towarzystwa Studiów Nowego Testamentu w Rzymie. 6 (1981) 388-389

— Zagadnienie podmiotu w Rz 7, 7-25. 4 (1977) 189-194

- Zbawcza inicjatywa Boga (według Ef 1, 3-14). 6 (1965) 328-346

— Z teorii i praktyki chrześcijaństwa w oparciu o 1 Tes 5.3 (1981) 155-162

ROSŁON Józef OFMConv, „Dlatego opuści mężczyzna ojca i matkę i złączy się z żoną" (Gen 2, 23-24). 2-3 (1955) 107-115

— „Impositio manuum” w Dziejach Apostolskich. 2 (1957) 102-114

- Logotechnika biblijna Clausa Schedla (1914-1986). 3 (1987) 220-231

— Zbawienie jako życie w oparciu o księgę Psalmów. 3 (1986) 177-197

- Z dyskusji nad Biblią: od Congara do Lohfinka. 4-5 (1966) 225-233

ROSPOND Stanisław, Onomastica sacra w Nowym Testamencie (JerozolimaJerusalem). 4 (1980) 207-212

ROSPOND Stanisław CM, Śp. prof. Stanisław Rospond. 1 (1983) 55-56

ROSTWOROWSKI Jan SJ, O znaczeniu Pisma świętego. 1-2 (1950) 97-110

ROSZKO Kazimierz ks., Uroczysta liturgia ormiańska (Rys historyczny i jej sprawowanie). 5-6 (1963) 280-290

Rozmowa z o. profesorem Augustynem Jankowskim OSB. 1 (1997) 56-60

ROŻEK Michał, Artystyczne fundacje błogosławionej królowej Jadwigi. 6 (1988) 497504

RÓŻYCKI Ignacy ks., Kościół katolicki na progu epoki nowych dziejów. 1 (1969) 112

RUBINKIEWICZ Ryszard SDB, Apokalipsa Abrahama. 4-5 (1974) 230-237

- Apokaliptyka u progu ery chrześcijańskiej. 1 (1988) 51-59

- Badania nad literaturą apokryficzną Starego Testamentu w wersji starocerkiewnosłowiańskiej na przestrzeni ostatnich dziesięciu lat. 4-5 (1975) 235-238

— Z badań nad literaturą pseudoepigraficzną Starego Testamentu. 1 (1979) 47-52

RUMAK Jerzy ks., Ewangelia dziecięctwa P. Jezusa a krytycy. 6 (1962) 344-352

— Święty Paweł a kwestia społeczna. 6 (1959) 533-549

RUMIANEK Ryszard ks., Śp. ks. Czesław Jakubiec (1909-1993). 1 (1994) 59-61

RUSECKI Marian ks., Problemy posoborowej dyskusji nad urzędem w Kościele. 4 (1983) 321-329

RYBACKI Kajetan ks., Śp. ks. Witold Marchel (1922-1990). 4 (1996) 271-274 
RYCHLICKI Czesław ks., Człowiek współczesny wobec tajemnicy odkupienia. 6 (1979) 329-336

RYNES Vaclav, Kult św. Stanisława w Czechach. 3 (1975) 136-137

RZESZEWSKI Marian ks., Homilie biblijne. 5 (1965) 300-305

- Słowo o Fenelonie. 4 (1957) 322-330

SALIJ Jacek OP, Teologia niedzieli. 4-5 (1967) 245-253

SALOMON Adam OFMConv, Śp. o. Józef Wiesław Leon Rosłon OFMConv (19291993). 1 (1986) 58-59

SCHENK Wacław ks., Błogosławieństwa w praktyce duszpasterskiej. 4 (1979) 239242

- Chrzest dzieci (Historia, teologia, wymogi duszpasterskie). 1 (1973) 2038

- Consecratio mundi. 4 (1979) 178-182

— Geneza i założenia reformy liturgicznej. 4 (1965) 205-211

- Pokuta sakramentalna osób duchownych. Zarys historyczny. 2-3 (1976) $82-85$

- Rozgrzeszenie zbiorowe w praktyce Kościoła na Zachodzie i w Polsce do 1975 r. 2-3 (1976) 128-134

- Rozwój hierarchii w Kościele. 4 (1983) 288-296

- Rozwój nauk liturgicznych. 5 (1962) 291-296

- Urzeczywistnienie się Kościoła w liturgii. 1 (1981) 6-13

— Z historii liturgii chrztu. 2 (1972) 89-96

SCHLETZ Alfons CM, O niektórych podręcznikach liturgicznych w dawnych seminariach duchownych w Polsce. 3 (1949) 193-209

SCHMATOVICH Janos ks., Medytacja nad historycznością przekazów o zmartwychwstaniu Jezusa. 1 (1993) 21-26

SCHNAYDER Jerzy, Z problematyki przekładu biblijnego. 4-5 (1971) 161-187

SCZANIECKI Paweł OSB, Curriculum vitae. 4 (1995) 290-291

- Dzieje ofiar mszalnych ludu w Polsce. 1 (1962) 29-43

— Eucharystia a wychowanie i samowychowanie. 3 (1959) 289-295

- Fundamenta eius (Objaśnienia części zmiennych Mszy św. na święto NMP Jasnogórskiej). 4-6 (1956) 209-215

- Gromniczna. 1 (1958) 55-62

- Krzak gorejący. 5-6 (1952) 469-474

- Obrzęd umywania nóg („,mandatum”). 2 (1958) 159-168 
- O homiliarzu praskim jako źródle dla dziejów Mszy świętej. 4 (1963) 173-187

- O. Karol van Oost i czasopismo „Misterium Christi”. 1-2 (1990) 56-60

- Ołtarz i duch ofiary. 4 (1995) 225-231

- Pamiątka dawnych zwyczajów liturgicznych. 1 (1960) 63-72

— „Paroisse et Liturgie” na cenzurowanym. 4-6 (1951) 431-434

- Przeżycie dogmatu łaski w liturgii. 5 (1959) 485-491

— Śpiew gregoriański w życiu zakonnic. 5 (1961) 252-261

- Wiadomości liturgiczne. 1-2 (1950) 157-160

— „Viventis et videntis”. 6 (1958) 507-515

SIATKOWSKA Ewa, Z kręgu współczesnych przekładów biblijnych. 6 (1987) 498509

SIEG Franciszek SJ, Siedem gwiazd - aniołowie siedmiu Kościołów (Ap 1, 20). 2 (1983) 131-137

- Sens terminów hieron i naos w Nowym Testamencie. 5-6 (1989) 335-341

— Życie Jezusa w Nazarecie w świetle Jego publicznej działalności. 4 (1987) 336-342

SIEG Jan SJ, Głos w kwestii znaczenia terminu ,alienacja” w encyklice „Redemptor hominis". 6 (1979) 365

SIKORSKI Bogdan bp, Odkupienie jako nowe stworzenie. 6 (1979) 307-322

SINKA Tarsycjusz CM, Dzieje i charakterystyka polskich pieśni nabożnych ku czci św. Józefa. 3 (1981) 182-185

- Dzwony w liturgii. 2 (1998) 115-121

— Organy w liturgii Kościoła. 3 (1998) 209-214

— Z teologii błogosławieństw. 3 (1996) 194-201

SITARZ Eugeniusz CM, Ocena władzy królewskiej w księdze Ozeasza. 3-4 (1960) 217-241

- Polskie przekłady mszału rzymskiego. 4-5 (1955) 205-229

- Zarys biblijnej doktryny o małżeństwie. 1-2 (1961) 23-31

SITKOWSKI Tadeusz ks., Dlaczego Kościół poświęcił Matce Boskiej dzień sobotni. 5-6 (1948) 315-317

- Udzielanie Komunii św. podczas Mszy św. i poza Mszą św. 5-6 (1948) 344-348

SKOP Gizela Marta, Śpiewy i muzyka we mszach z udziałem dzieci. 2-3 (1977) 135145 
SKOWRONEK Alfons ks., Arcybiskup dr Ramsey pragnie unikać przeszkód na drodze do jedności. 6 (1967) 371-372

— Próby współczesnego ożywienia wiary eucharystycznej. 6 (1968) 351-360

- W stronę ekumenicznego czynu. 4-5 (1967) 253-260

SKRABAL Paweł OP, Ruch biblijny w Czechosłowacji. 2 (1948) 102

SKWARCZEWSKI Leonard ks., Znaleziska archeologiczne w Qumran w problematyce badań nad kultem ofiarniczym u Sadokitów. 4 (1963) 196-201

SKWIERAWSKI Kazimierz ks., Przypowieść o synu marnotrawnym w interpretacji Tertuliana. 4 (1984) 313-318

SŁOMKA Walerian ks., Liturgia a duchowość chrześcijańska. 4-5 (1969) 239-248

SŁOMSKI Wojciech, Ekumenizm w Nowym Testamencie. 2 (1996) 120-123

Słowo Towarzystwa Biblijnego w Polsce na Ekumeniczne Dni Biblijne 1998. 1 (1998) 63-64

Słowo Towarzystwa Biblijnego w Polsce na święto Biblii 1996. 2 (1996) 123-124

SMEREKA Władysław ks., Annasz i jego udział w procesie Chrystusa. 2 (1954) 139155

- Betlejem w historii i legendzie. 5-6 (1948) 330-343

— Doksologia „Chwała Ojcu i Synowi i Duchowi Świętemu”. 3 (1949) 186193

- Droga krzyżowa w Jerozolimie. 1 (1964) 24-34

- Ecce Mater tua. 4-6 (1956) 244-261

— Ewangelia księgą Roku Świętego. 3 (1974) 161-168

- Godzina biblijna i jej znaczenie. 1 (1960) 1-37

- Hymn do Matki Boskiej. 1 (1951) 38-56

- Indywidualne czytanie Pisma świętego. 2 (1952) 168-173

— Instrukcja o nauczaniu Pisma św. 2 (1952) 174-177

- Ks. prof. Aleksy Klawek jako wykładowca i komentator Psalmów (ze wspomnień ucznia). 6 (1970) 279-291

- Myśl teologiczna i społeczna św. Pawła w Liście do Filemona. 1 (1953) 424

- Najstarsza legenda o Matce Bożej. 1 (1963) 29-36

- Najstarsza legenda o Matce Bożej (Protoewangelia Jakuba). 5-6 (1963) 262-272

- Nieznany żywot Pana Jezu Krysta z pierwszej połowy XV wieku. 4 (1948) 246-250

- Początki chrześcijaństwa wśród pogan. 3 (1965) 180-184 
- Początki i rozwój ruchu biblijnego w Polsce. 2 (1958) 81-113

- Polskie Towarzystwo Teologiczne w hołdzie bł. królowej Jadwidze. 6 (1978) 326-329

- Potrójne kuszenie Chrystusa na tle marzeń mesjańskich. 1-3 (1956) 33-51

- Proces Chrystusa w świetle najnowszych badań. 3 (1962) 154-160

- Prof. Witwicki jako tłumacz Ewangelii. 3-4 (1961) 114-120

- Protoewangelia Jakuba na ziemiach polskich. 5-6 (1948) 349-350

- Requiem aeternam. 5 (1949) 330-335

- Ruch biblijny w Polsce. 2 (1948) 97-101

- Wieczerza Pańska w I liście św. Pawła do Koryntian. 2 (1949) 111-121

- Wystawa biblijna z okazji uroczystości jubileuszowych ks. Jakuba Wujka TJ. 1-2 (1950) 151-153

- Zagadnienie praźródła przekładu Ewangelii dokonanego przez ks. Jakuba Wujka. 6 (1955) 289-305

- Zarys bibliograficzny ważniejszych wydań Biblii ks. Wujka (1593-1950). 1-2 (1950) 64-91

— Ze Zjazdu Teologicznego w Krakowie. 4 (1948) 254-263

— Z wydawnictw biblijnych N. T. 2-3 (1955) 135-149

SMOLEŃSKI Stanisław ks., Polska teologia moralna w latach od 1880 do 1939. 2 (1966) 99-114

SOBCZYK Władysław ks., Chrzest dzieci w życiu wspólnoty parafialnej. 2 (1972) 104-108

- Zagrożenia Dnia Pańskiego. 1 (1981) 13-18

SOBECZKO Helmut ks., Działalność o. Franciszka Małaczyńskiego OSB. 1-2 (1990) 78-89

- Postawy wewnętrzne i zewnętrzne w czynnym uczestnictwie wiernych we Mszy świętej. 3 (1989) 207-224

- Prace Komisji Liturgicznej Episkopatu Polski nad realizacją konstytucji liturgicznej w Polsce w latach 1963-1975. 4-5 (1985) 290-312

- Sakrament bierzmowania w duszpasterstwie. 1-2 (1975) 50-65

- Teologiczny i pastoralny wymiar święcenia niedzieli w sobotni wieczór. 3 (1994) 162-175

SOKOŁOWSKI Ksawery ks., Z dyskusji nad zmartwychwstaniem Jezusa. 4-5 (1972) 219-228

SOSSALLA Jan ks., Milczenie Ewangelii św. Jana o słowach ustanowienia Eucharystii świętej. 5-6 (1963) 231-261 
SROKA Józef ks., Apostolstwo liturgiczne ks. Michała Kordela w „Mysterium Christi”. 4 (1976) 221-227

- Język polski ksiąg liturgicznych. 2 (1978) 73-82

- Nowe modlitwy eucharystyczne. 2-3 (1969) 123-134

- Odnowa liturgii przed Soborem Watykańskim II w Polsce. 4 (1976) 179189

- Posoborowe Ordo Missae. 6 (1969) 350-357

STACH Piotr ks., Daniel Rops: Dzieje Chrystusa. 2 (1951) 170-203

- Miejsce zaśnięcia N. Maryi Panny. 1 (1951) 59-82

- Prolegomena do Nowego Testamentu. 3-4 (1950) 240-248

- Sobór Trydencki a czytanie Pisma świętego w języku ludowym. 4 (1948) 202-208

STACHOWIAK Lech ks., Geneza dydaktycznego schematu „Dwóch dróg” w piśmiennictwie międzytestamentalnym. 2-3 (1969) 75-85

— Ks. Aleksy Klawek jako egzegeta i tłumacz Biblii. 4 (1980) 191-201

- Nowe wydanie krytyczne Biblii hebrajskiej. $4-5$ (1970) 232-234

- Odwieczne pochodzenie Słowa (J 1, 1-5). 3 (1972) 156-168

- Refleksje nad biblijnym pojęciem pokory. 3-4 (1960) 199-216

- Spór między Jahwe a Izraelem (Jr 2, 1-20). 2 (1967) 72-85

- Stary Testament w świetle ostatnich badań krytycznych. 1 (1989) 1-10

- Teologiczno-biblijna problematyka czasu. 5 (1964) 291-303

STAHR Jan, Dwaj świadkowie Apokalipsy. 5-6 (1950) 267-294

STANIEK Edward ks., Sekrety dobrego kaznodziejstwa w ujęciu św. Augustyna. 4 (1989) 302-308

- Stosunek chrześcijan starożytnych do dziecka przed narodzeniem według ojców Kościoła. 1-3 (1991) 47-53

STAROWIEYSKI Marek ks., Dzieje Pawła i Tekli (przekład). 4-6 (1991) 118-126

- Męka Pańska wedle diatessaronu Tacjana Syryjczyka. 4 (1989) 259-268

STEFANIAK Ludwik CM, Apokryf aramejski księgi Rodzaju. 6 (1957) 445-451

- Chrystus w świetle badań współczesnej epigrafii, paleografii i archeologii. 3 (1959) 230-245

- Historyczność zmartwychwstania Chrystusa w listach św. Pawła. 6 (1955) 306-327

- Kierunki i postulaty współczesnej biblistyki katolickiej. 3-4 (1960) 269285

— Kim byli członkowie sekty z Qumran. 3-4 (1961) 129-133 
- Kronika odkryć nad Morzem Martwym. 6 (1957) 463-467

— „Mulier amicta sole” (Ap 12, 1-17). 4-6 (1956) 262-283

- Przypowieść o modlitwie w Ewangelii św. Łukasza. 2-3 (1955) 84-107

- Sensacyjne odkrycie tekstu hebrajskiego. 3-4 (1960) 363-364

- Sposób zmartwychwstania ciał na podstawie listów św. Pawła. 2 (1957) 81-101; 3 (1957) 189-200

- Sprawozdanie z czternastego Międzynarodowego Kongresu Studiorum Novi Testamenti Societas. 1 (1960) 73-76

— Śp. ks. prof. Stanisław Styś TJ (1896-1959). 3 (1959) 317-319

- Tworzywo pojęciowe i literackie doktryny św. Pawła Apostoła. 3 (1965) $152-161$

- Zmartwychwstanie Chrystusa rękojmią naszego zmartwychwstania w świetle listów św. Pawła. 1- 2 (1956) 51-60

STEFAŃSKI Jerzy ks., Abp A. Bugnini (1912-1982) promotor posoborowej odnowy liturgicznej. 4 (1983) 329-334

- Adaptacja liturgiczna przyszłością odnowy liturgicznej. 1-2 (1990) 20-36

- Antonio Rosmini - prekursor odnowy liturgicznej. 5 (1981) 281-289

- Komentarze do nowych czytań mszalnych. 4-5 (1970) 240-242

- Modlitwy eucharystyczne z udziałem dzieci. Nowa szansa pastoralna. 5 (1988) 427-439

- Msze wspólne o świętych (Commune sanctorum) w liturgii rzymskiej. 6 (1969) 333-342

- Nowa redakcja Mszy wspólnych (communio) w mszale Pawła VI. 2-6 (1992) 74-82

STENCEL Eugeniusz ks., XXI sympozjum pastoralno - liturgiczne „Święta paschalne w liturgii, duszpasterstwie i tradycji polskiej”. 1-3 (1991) 73-74

— Niedzielna Msza św. w świetle wypowiedzi młodzieży. 3 (1994) 211-217

STĘCHŁY Stanisław ks., Profesor, który pamiętał. 6 (1983) 518

STĘPIEŃ Jan ks., Apostolstwo w ujęciu biblijnym. 5-6 (1973) 280-289

- Czas paruzji w listach św. Pawła. 6 (1961) 291-299

- Drugi znak paruzji w eschatologii św. Pawła. 2 (1962) 65-72

- Nauka św. Pawła o zmartwychwstaniu. 2-3 (1963) 71-79

- Nauka św. Pawła o śmierci. 5 (1962) 283-291

- Oczekiwania paruzji w listach św. Pawła. 3-4 (1961) 120-125

- Pawłowy charakter nauki dogmatycznej i moralnej Listów do Tesaloniczan. 3-4 (1960) 243-267 
— Problem „Joannitów” w świetle dokumentów z Qumran. 6 (1957) $452-462$

— Problem podwójnej perspektywy paruzyjnej w listach św. Pawła. 5 (1961) 205-209

- Problem wzajemnego stosunku literackiego Listów do Tesaloniczan i próby jego rozwiązania. 5 (1960) 414-435

STĘPIEŃ Piotr, Współczesna architektura sakralna w Irlandii. 3 (1984) 231-233

- 175 lat Brytyjskiego i Zagranicznego Towarzystwa Biblijnego w Polsce. 4-6 (1991) 150-151

STRAॄKOWSKI Henryk ks., Komentarz Habakuka. 6 (1957) 394-416

- Pismo święte w obradach Soboru. 2-3 (1963) 143-145

- Problem historyczny i literacki księgi Jozuego. 3-4 (1961) 82-95

- Wykłady dla duchowieństwa w Katolickim Uniwersytecie Lubelskim nt. Pismo święte w duszpasterstwie współczesnym. 1-3 (1956) 143-159

STRUS Andrzej SDB, Legenda, tradycja i historia o zaśnięciu i wniebowzięciu NMP. 2 (1984) 127-139

- Rozwój proroctwa o Emmanuelu jako przykład hermeneutyki w Starym Testamencie. 3 (1986) 197-211

- Sympozjum na temat inkulturacji na uniwersytecie salezjańskim w Rzymie (1983). 2 (1984) 148-150

STRYCHARZ Edward TChr, Teologiczno - liturgiczne aspekty szabatu. 5 (1988) 394-407

STRZELECKA Kinga OSU, „Ut putabatur — filius Joseph” (Łk 3, 24). 1 (1964) 4749

STRZELECKI Stanisław ks., O czytaniu Pisma świętego przez kapłana. 2 (1987) 159163

— Śp. ks. Tadeusz Paprocki (1927-1989). 3-6 (1990) 165-166

STYŚ Stanisław SJ, Duchowy tragizm Jeremiasza. 2 (1949) 81-93

- Nadprzyrodzony charakter profetyzmu izraelskiego w świetle pism prorockich. 1 (1959) 1-23

- Protoewangelia a Maryja. 1 (1952) 9-25

SULOWSKI Julian SJ, Śp. ks. Alfred Kazimierz Cholewiński SJ. 5-6 (1989) 394-395

SUSKI Andrzej ks., Struktura literacka perykopy o dobrym Pasterzu (J 10, 1-18). 5-6 (1976) 271-279

SYKULSKI Józef ks., Trzy typy prorockie. 3 (1951) 268-292; 4-6 (1951) 353-380

SWETNAM James SJ, Hesed w Starym Testamencie a eloes w Nowym. 4 (1998) 251260 
SZAFRANIEC Sykstus OSPPE, Święto Matki Bożej Częstochowskiej. 4-6 (1956) 205-208

— Z badań nad genezą tytułu Najświętszej Panny „Królowej Polski”. 4 (1957) 271-279

SZAFRAŃSKI Adam ks., Modlitwa wiernych. 4 (1964) 230-237

SZAMOTA Stanisław ks., Dzień Pański w sobotę się zaczyna. 1 (1985) 50-53

— Eucharystia w liturgii Kościoła. 4 (1962) 215-222

- Msza z ludem. 3 (1966) 166-172

- Odnowione obrzędy sakramentu małżeństwa. 6 (1971) 300-301

- Odnowiony ryt chrześcijańskiego pogrzebu. 4-5 (1972) 249-252

- Pobożność Kościoła. 2 (1964) 95-103

— Sztuka w służbie liturgii. 4 (1958) 318-331

- Wielkanocne jednanie pokutników z Kościołem. 2 (1960) 127-138

- Zgromadzenie w imię Chrystusa. 4-5 (1960) 252-258

- Życie religijne w Qumran. 2-3 (1969) 123-144

SZCZEPANIEC Stanisław ks., Posługi liturgiczne w zgromadzeniu eucharystycznym. 6 (1987) 534-541

SZCZUREK Tadeusz ks., Ks. prof. Seweryn Kowalski (1890- 1956). 1 (1957) 1-8

- Ks. Roman Głodowski (1891-1978). 2 (1980) 110

— Śp. ks. Piotr Federkiewicz (1900-1977). 6 (1977) 342

- „Ukazał się aniołom” (1 Tm 3, 16). 4 (1977) 195-198

- Znaczenie struktur literackich dla hermeneutyki na przykładzie zwiastowań Mt 1, 18-25; Łk 1, 26-38 oraz cudu w Kanie (J 2, 1-11). 4-5 (1975) 226-228

SZEWC Eugeniusz ks., Autorstwo ksiegi Henocha. 1 (1976) 20-26

SZKODOŃ Jan ks., Małżeństwo i rodzina w twórczości pisarskiej i działalności pastoralnej kardynała Karola Wojtyły. spec. (1979) 32-35

- Udział chrześcijan w potrójnej misji Jezusa Chrystusa według encykliki „Redemptor hominis”. 6 (1979) 341-347

SZLAGA Jan ks., Apokaliptyczne „co ma nastapić niebawem” a oczekiwanie paruzji. 4-5 (1975) 230-234

- Chrystus jako fundament Kościoła. 6 (1972) 307-315

— Henry Joel Cadbury (1883-1974). 6 (1975) 283-285

— Główne tematy w ewangelii Jezusa Chrystusa. 2-3 (1979) 90-104 
- Homilia we Mszy św. za śp. ks. Wojciecha Danielskiego, w trzydziestym dniu od śmierci, wygłoszona w kościele akademickim KUL, 24 stycznia 1986 r. 5 (1986) 443-446

- Obraz budowania w Nowym Testamencie. 6 (1974) 311-319

- Obrzędy Starego Przymierza według Hbr 9, 6-7. 5-6 (1976) 279-284

— V Tydzień Biblijny na KUL-u. 4 (1977) 217

— Pismo święte w nauczaniu Jana Pawła II. 1 (1988) 75-84

— Śp. ks. Tadeusz Penar. 4 (1989) 308-309

- Zmarł Charles Harold Dodd. 4-5 (1974) 279-282

SZREDER Feliks CR, Święty Józef a zjednoczenie hipostatyczne. 4-5 (1974) 215-220

— Ważniejsze metafory eklezjologiczne w Piśmie św. 6 (1962) 321-329

SZTEINKE Anzelm OFM, Polacy w Kustodii Ziemi Świętej. 6 (1986) 493-495

SZUBZDA Walerian ks., Kościół a Kościoły według doktryny świętego Pawła. 6 (1962) 330-336

SZWAGRZYK Tadeusz ks., Anioł Pański. 4-6 (1956) 283

- Benedictio mensae. 5 (1959) 517-519

- Binacja w zarysie prawno-historycznym. 2 (1962) 101-112; 3 (1962) 166174

- Confiteor przy udzielaniu ostatnich sakramentów. 6 (1958) 556-557

- Czy może być kilka Mszy św. żałobnych w dniu pogrzebu? 6 (1958) 553555

- Dopuszczenie obcego kapłana do ołtarza. 1 (1959) 54-62

- Dotykanie naczyń świętych i pranie bielizny kielichowej. 2 (1959) 194197

- Dyrektywy Episkopatu Polski w związku z instrukcją Św. Kongregacji Obrzędów o muzyce sakralnej i liturgii. 5-6 (1963) 307-313

- Ks. bp dr Zdzisław Goliński. 5-6 (1963) 318-319

- Ministrant do Mszy św. i jego ubiór. 4 (1957) 317-322

- Msza święta za wiernych. 3-4 (1961) 157-164

- Msze św. wotywne. 3-4 (1960) 331-340

— Msze św. żałobne. 6 (1959) 573-588

- Odpowiedź Św. Kongregacji Obrzędów z dnia 16 czerwca 1956 r. na zapytania i wątpliwości związane z interpretacją dekretu „De rubricis ad simpliciorum formam redigendis" $\mathrm{z}$ dnia 23 marca 1955 r. 3 (1957) 219220

- Patena przy udzielaniu Komunii św. 2 (1959) 198-199 
- Pocałunek pokoju. 5 (1959) 520-523

- Przechowywanie Najświętszego Sakramentu w historii i liturgii Kościoła. 1-3 (1956) 92-106; 1 (1957) 34-52; 4 (1957) 283-299

- Renowacja św. Postaci. 4 (1958) 347-349

- Samobójstwo i pogrzeb kościelny. 5 (1961) 232-242

- 700-lecie święta Bożego Ciała. 5 (1964) 325-327

- Sprawowanie pewnych funkcji przez diakona w nadzwyczajnych wypadkach. 4-5 (1955) 250-251

- Szafarz nadzwyczajny sakramentu bierzmowania. 2 (1958) 141-152

— Światło nieustające w liturgii Kościoła. 1 (1955) 24-37

- Uprawnienia płynące z przyjętych święceń lektoratu względem kościelnych błogosławieństw. 4-5 (1955) 251-254

- Uwagi do dekretów Stolicy Apostolskiej. 4 (1964) 250-251

- Uwagi do „De usu grammophonis et de horis mixtis in Ecclesia”. 4 (1957) 316-317

- Uwagi do motu proprio: Indulty uzupełniające konstytucję apostolską „Christus Dominus” papieża Piusa XII. 1 (1957) 61-63

- Uwagi do „Wyjaśnienia Świętej Kongregacji Obrzędów dotyczące czynności liturgicznych w czasie Świętego Triduum zgodnie z odnowionym porządkiem Wielkiego Tygodnia". 1 (1957) 54-56

- Wyjaśnienie dotyczące ważności koncelebry Mszy św. 1 (1958) 69-70

SZWARC Urszula, Głód Słowa Pana. Sens teologiczny wyroczni Am 8, 11-12. 2 (1983) 122-131

— „Iść za Panem”. Sens teologiczny tekstu 1 Krl 18, 21.4 (1978) 184-193

SZYMANEK Edward TChr, Ekumeniczny przekład Listu do Rzymian. 6 (1969) 328332

- Teksty biblijne w liturgii. 2 (1978) 57-63

- Wiara jako postawa człowieka w teologii św. Pawła. 4 (1984) 297-305

- Wiara jako przedmiot nauczania według św. Pawła. 3 (1983) 214-223

- Wolność ewangeliczna na podstawie Listu do Galacjan. 6 (1980) 308-314

SZYMAŃSKI Stanisław ks., Historia officium Bożego Ciała. 3-4 (1950) 219-229

SZYMIK Stefan MSF, Dz 6, 1-7 w świetle dotychczasowych badań. 6 (1986) 477-482

- Podstawowe aspekty analizy narracyjnej tekstu biblijnego. 2 (1996) 90103

- Współczesne metody analizy tekstu biblijnego na przykładzie Mk 5, 120. 2 (1995) 94-100 
ŚLIWA Tadeusz ks., Śp. ks. Tadeusz Szczurek (1922-1981). 1 (1983) 52-53

ŚLIWIŃSKA Iwona, Bogactwo liturgii ofiary Odkupienia. 3 (1984) 271-274

ŚLIWOWSKA Wacława, Wspomnienia nauczycielki. 5 (1986) 462

Śpiewnik kościelny, cz. I. 1 (1970) 44-60

ŚPIKOWSKI Władysław ks., Aktualne znaczenie słów konsekracyjnych. 5-6 (1948) 305-314

- Projekt rozwiązania kwestii polskich śpiewów mszalnych. 1 (1952) 85-86

- Uaktywnienie uczestnictwa wiernych we Mszy św. 5-6 (1950) 323-340

ŚWIERCZEK Edmund OFM, Zamysły serca czyli skłonność dobra i zła w nauczaniu bliblijnym. 1 (1997) 358-364

ŚWIERZAWSKI Wacław ks., Duszpasterskie implikacje thumaczenia liturgii. 2 (1978) 94-100

- Dwadzieścia pięć lat odnowy liturgicznej (Wprowadzenie do sympozjum). 1-2 (1990) 5-8

- Dialektyczny dynamizm sakramentów pokuty i Eucharystii. 2-3 (1976) 106-116

- Egzegeza duchowa Pisma św. w liturgii. 4-5 (1972) 234-241

— Hermeneutyka w liturgii. 2-3 (1971) 131-147

- Homilia hagiograficzna w posoborowej odnowie życia chrześcijańskiego. 2-3 (1979) 139-148

- Homilia liturgiczna. 4 (1963) 201-211

- Jan Paweł II o liturgii. 6 (1980) 337-344

- Katecheza liturgiczna. 5 (1964) 303-310

- Kazanie o posłudze organisty w czasie sprawowania świętej liturgii. 1 (1986) 75-78

- Kongresy liturgiczne w Wiedniu. 6 (1972) 345-350

- Liturgia u podstaw autentycznej interpretacji życia kapłańskiego. 6 (1972) 330-344

- Liturgiczna formacja kapłana. 2-3 (1970) 105-111

- Metodyczne uwagi na temat homilii. 3 (1972) 202-212

— Niektóre elementy formacji liturgicznej. 4 (1973) 176-185

- Odnowiony obrzęd pokuty i pojednania pomocą w pogłębieniu życia kontemplacyjnego. 3 (1985) 221-237

— Odo Casel — mystagog i teolog (1886-1948). 6 (1978) 310-319

- Odo Casel (1886-1948). Życie i dzieło. 2 (1988) 90-105

— Papieski Instytut Liturgiczny w Rzymie. 5 (1965) 313-316 
- Pismo św. w liturgii. 2-3 (1963) 105-113

- Sacerdotes mysteriis vivens (ks. Karol Csesznak). 2-3 (1970) 133-139

- Setna rocznica urodzin ks. Jana Korzonkiewicza (1877-1932). 6 (1977) 324-330

- Synody diecezjalne i reforma liturgii po Soborze Watykańskim Drugim. 3 (1974) 169-187

- Teologia liturgii. 2 (1962) 112-118

- Tłumaczenie liturgii rzymskiej na języki ojczyste. 2 (1978) 63-73

- Treść liturgicznej homilii. 1 (1964) 34-40

- Vetera et nova. 4 (1976) 177-178

— Wierność rubrykom a osobista inicjatywa liturgiczna. 5-6 (1963) 272-279

ŚWIĘCICKI Andrzej, „Redemptor hominis” a chrzescijańskie spojrzenie na kulturę. 6 (1979) 358-364

ŚWIĘTOCHŁOWSKI Robert OP, Leonard Niezabitowski tłumaczem Biblii Leopolity. 5 (1961) 195-197

- O. Jacek Woroniecki OP. 4 (1949) 293-296

- W dziesiątą rocznicę śmierci o. Efrema Glińskiego OP (1953-1963). 5-6 (1963) 319-320

ŚWISTAK Jan ks., Przygotowanie do duszpasterstwa biblijnego w seminariach duchownych. 4 (1981) 221-232

TARGOSZ Andrzej ks., Formy duszpasterstwa biblijnego młodzieży. Na kanwie działalności Felicji Żurowskiej. 6 (1985) 390-398

— Kółka biblijne księdza profesora Władysława Smereki. 2 (1984) 103-108

TARKOWSKA Halina, Deus Caritas est. 2-3 (1963) 134-142

TARNOWSKI Janusz ks., Język modlitwy liturgicznej a język dziecka. 2-3 (1977) 127-135

TASZYCKI Witold, Ks. Aleksy Klawek jako onomasta. 6 (1970) 291-293

T[EKLAK] Cz[esław] OFM, Sprawozdanie z sekcji homiletyczno-duszpasterskiej PTT w Krakowie. 1 (1967) 54-55

TOMALIK Stanisław, Biuletyn studiów o Karaitach. 3 (1974) 188

TOMASZEWSKI Eugeniusz ks., Formizm a problem chrystocentryczny. 5-6 (1952) 423-435

TOMCZYK Dominik SchP, Krag biblijny. 1 (1984) 79-83

- 50 lat Katolickiego Dzieła Biblijnego w RFN. 1 (1985) 35-40 
TOWARZYSTWO BIBLIJNE, „Bóg powierzył nam słowo pojednania” (2 Kor 5, 15). Słowo Towarzystwa Biblijnego w Polsce na Ekumeniczne Święto Biblii 1977. 2 (1997) 147-149

TRIACCA Achile SDB, Dom Burkhard Neunheuser (przegląd bibliograficzny). 6 (1978) 319-325

- Odo Casel i ruch biblijny. 2 (1988) 105-128

TRONINA Antoni ks., Jeszcze o imieniu Maria(m). 3-6 (1990) 127-130

— „Księga Jasar” i jej ślady w Biblii hebrajskiej. 3 (1987) 186-190

- Maria - Syjon — Golgota; transpozycja symboli. 2 (1983) 116-122

— „Pierwszego dnia po szabacie” (Ps [23] 24). 1 (1984) 56-65

— „Psalmy eucharystyczne” todah. 4 (1988) 286-299

- Saduceusze - historia i doktryna stronnictwa. 4 (1981) 215-220

- Szabat archetypem niedzieli w Starym Testamencie. 2 (1994) 95-103

— Śp. ks. prof. dr hab. Lech Remigiusz Stachowiak (1926-1997). 4 (1997) 296-299

- Świadectwa epigraficzne o początkach Izraela. 1 (1989) 21-27

- W poszukiwaniu świętego Graala. 2 (1998) 134-138

TSCHUSCHKE Michał ks., Diakon, prezbiter, biskup — znaki osobowe w zgromadzeniu liturgicznym. 4 (1983) 307-311

- Teologia chrztu dzieci według nowego rytu w aspekcie personalistycznym. 2 (1972) 81-89

TURSKA Maria., Myśli o niedzieli. 1 (1949) 57-61

TYLOCH Witold ks., Księga Izajasza z Qumran. 6 (1957) 382-393

— Pieśń o Słudze Jahwe w drugiej części księgi Izajasza. 4 (1958) 273-291

- Sprawozdanie z obrad sekcji biblijnej w Lublinie. 5 (1958) 448-458

TYMCZAK Adolf ks., Uczestnictwo Najświętszej Maryi Panny w ofierze krzyżowej. 5 (1960) 436-448

ULACZYK Antoni SCJ, Sprawozdanie ze zjazdu biblistów w ramach Kongresu Polskich Teologów (21-23 IX 1971). 6 (1971) 330-333

URBAN Wincenty ks., Najstarszy benedykcjonał w Bibliotece Kapitulnej we Wrocławiu. 3-4 (1960) 303-320

- Nieznane polskie teksty religijne z biblioteki św. Jakuba w Nysie (z XVI w.). 1-3 (1956) 106-124

- 50-lecie kapłaństwa ks. prof. Władysława Smereki. 6 (1981) 337-340

- Próba wyjaśnienia pochodzenia pontyfikału z r. 1435 przechowywanego w Bibliotece Kapitulnej we Wrocławiu. 3-4 (1961) 148-152 
- Przemówienie z okazji otwarcia XII Kongresu Biblistów Polskich we Wrocławiu. 4-5 (1975) 148-150

URBAŃSKI Stanisław ks., Modlitwa brewiarzowa. 3 (1989) 225-231

- Modlitwa liturgiczna. 2 (1987) 164-169

- Modlitwa kontemplacyjna dziś. 4 (1987) 362-365

- Pojęcie świętości w kazaniach biograficznych o. Józefa Męcińskiego (1748-1814). 6 (1988) 532-535

VANHOYE Albert SJ, Kapłaństwo Chrystusa i kapłaństwo chrześcijan. 1-3 (1991) 418

van VELDHUIZEN Piet, Prawe ucho Malchusa (J 18, 1- 11). 4 (1989) 276-278

WALICZEK Kazimierz ks., Poetyckie przekłady pojedynczych psalmów w XIX wieku. 4 (1957) 266-271

— Szkic historyczny przekładów Psałterza do XIX wieku. 2 (1957) 179-189

WALISZEWSKI Stanisław, Całun Turyński oczami lekarza. 5 (1984) 432-447; 6 (1984) 524-540

- Nowe stwierdzenia w sprawie Całunu Turyńskiego. Sprawozdanie ze Zjazdu Syndologicznego w Trani (1984). 6 (1985) 409-416

- Uwagi o Całunie Turyńskim. 1 (1953) 50-57; 2 (1954) 68-106

WALOSZCZYK Konrad ks., Qahal Jahwe jako pierwotyp zgromadzeń liturgicznych. 4-5 (1974) 204-211

WARZECHA Julian SAC, Błogosławić czy wielbić Pana. W sprawie przekładu. 4 (1997) 283-287

- Posłanie Słowa w Ps 147. 5-6 (1989) 329-334

— Wyrażenie „posłać Słowo” w Iz 9, 7.4 (1994) 225-234

WAWRZYNIAK Franciszek ks., Analiza doktrynalnych orzeczeń Soboru Trydenckiego o konieczności sakramentu chrztu dla zbawienia niemowląt. 1 (1973) 34-47

- Doktrynalne i teologiczne podstawy katolickiej sakramentologii. 6 (1971) 288-300

- Uniwersalna idea soteryczna a zbawienie dzieci nie ochrzczonych. 6 (1967) 348-361

- Zarys historii zbawienia w teologicznej refleksji ks. Ignacego Ró życkiego. 5 (1978) 253-262

WERYŃSKI Henryk ks., Ekumeniczny wieczór biblijny za Oceanem. 5 (1965) 308309

- Geneza aktu poświęcenia ludzkości Sercu Jezusowemu. 2-3 (1963) 148149

— Nowe odkrycia na Masadzie. 1 (1964) 51-52 
- O poświęceniu rodzin Sercu Matki Bożej. 4 (1964) 254-256

— Pięcioksiagg po japońsku. 5 (1964) 323

- Pismo święte w języku Hindu. 5 (1964) 323

— Pismo święte w języku Gujerati. 5 (1964) 323

- Ponadwyznaniowe stowarzyszenie liturgiczne. 5 (1965) 309-313

— Śp. ks. prof. Józef Archutowski. 5 (1964) 323

- Zakończenie prac na Masadzie. 4 (1964) 256-257

— Zasłużony prekursor ks. Jan Korzonkiewicz. 6 (1972) 351-354

— Z frontu archeologicznego w Izraelu. 4 (1964) 257

WESOŁOWSKA Germana Zofia s., Ona żyła liturgią. O siostrze Renacie niepokalance w czterdziestą rocznicę śmierci. 1 (1997) 38-48

WĘGRZYNIAK Tomasz OP, Słynny mariolog polski o. Justyn Zapartowicz (Miechowita) OP. 1 (1951) 113-121

W[ĘSIERSKA] I[rena], Myśli o Piśmie świętym według Ernesta Hello 1 (1952) 69-70 WĘSIERSKA Irena, Pozdrowienie Anielskie jako modlitwa. 1 (1959) 109-113

W. I., Filozof polski o śpiewie gregoriańskim. 4 (1952) 351-353

- Nowe wykopaliska w Jerycho. 4 (1952) 364-365

WICHER Władysław ks., Kontemplacja i Eucharystia. 6 (1968) 360-363

WIELGAT Włodzimierz ks., Wiara w Starym Testamencie w świetle filologii i teologii. 1 (1969) 12-21

WIESZCZAK Antoni SJ, Perspektywy reformy liturgicznej. 4-5 (1967) 234-244

WINIARSKI Karol CSsR, Stosunek Tradycji do Pisma świętego według konstytucji „O Bożym Objawieniu”. 4-5 (1968) 197-208

WIŚNIEWSKI Grzegorz OFM, O. Gabriel Maria Allegra - misjonarz i biblista. 1 (1978) 35-38

WIT Zbigniew ks., Aspekt liturgiczny muzyki kościelnej. 3 (1978) 117-129

— Błogosławieństwo organów. 4 (1979) 242-245

- Pożegnanie ks. dra Wojciecha Danielskiego - Warszawa 30 XII 1985 r. 5 (1986) 441-442

— Specjalne Modlitwy Eucharystyczne. 2-3 (1977) 98-112

WITASZEK Gabriel CSsR, Amos z Tekoa, prorok przyszłości. 1-3 (1991) 18-25

- Bez sprawiedliwości społecznej nie ma zbawienia (Iz 58, 1-13, 54). 2 (1997) 105-113

- Sprawiedliwość społeczna a odpowiedzialność indywidualna (Ez 18). 3 (1996) 154-164

— Tendencje partykularystyczne w gminie qumrańskiej. 3 (1995) 165-181 
- Wspólnota izraelska w świetle społecznej krytyki proroka Amosa. 3-6 (1990) 105-111

WITCZYK Henryk ks., Historyczno-prorockie tło dzieła kronikarskiego. 1 (1996) 1-14

- Powrót do Boga i wspólnoty. Zadośćuczynienie za grzechy według Deuteroizajasza i księgi Psalmów. 2 (1997) 86-104

WITEK Stanisław ks., Teologia pokory w Starym Testamencie. 3 (1968) 129-139

WITTLIEB Marian ks., Projekt polskiego słownika onomastyki biblijnej. 3 (1988) 229-230

WITTLIEB Marian ks., STAROWIEYSKI Marek ks., Opowiadanie o Józefie z Arymatei (przekł. Marek Starowieyski). 1 (1976) 27-34

WŁODARCZYK Stanisław ks., Antyteza Pawłowa sarx - pneuma w interpretacji św. Jana Chryzostoma. 4 (1977) 198-201

- Biblijne podstawy teologii laikatu. 2-3 (1979) 124-130

- Człowiek obrazem Boga według Jana Chryzostoma. 3-6 (1990) 121-127

- Język biblijny - ,język” Boga jako wzór języka w przekazywaniu wiary. 5 (1980) 258-263

- Język królestwa Ebli. 6 (1978) 330

- Miłosierdzie Jezusa w historii zbawienia (konferencje biblijne). 4 (1984) 355-363

- Misterium paschalne punktem kulminacyjnym historii zbawienia (refleksje egzegetyczno-metodologiczne). 3 (1984) 247-255

- Odkupiciel człowieka - Jezus Chrystus ośrodkiem wszechświata i historii. 6 (1979) 303-307

- Powrót do zasad teorii synkatabasis we współczesnej egzegezie katolickiej. 2 (1997) 113-118

- Rola synkatabasis w interpretacji Pisma św. według św. Jana Chryzostoma. 4-5 (1974) 246-251

- Tradycja jerozolimska grobu Najświętszej Maryi Panny w świetle tekstów Pisma św. i Tradycji. 6 (1980) 331-337

— Zwiastowanie Maryi zapowiedzią nadejścia „pełni czasów”. 3 (1983) 206213

WŁOSIŃSKI Marian ks., Implikacje teologiczne Syr 17, 1-14. 3 (1981) 165-173

WODECKI Bernard SVD, Aspekty soteriologiczne Przymierza synajskiego 1 (1995) $1-17$

- Dni judaistyczne w Pieniężnie. 6 (1980) 498-500

— „Dokument miedziany” z groty III w Qumran. 1 (1957) 63-66 
- Komunikat o Kongresie Światowej Federacji Apostolatu Biblijnego w Wiedniu. 4-5 (1972) 272

— Kongres biblijny w Ljubljanie (1996). 4 (1996) 263-267

- Międzynarodowy Kongres w Jerozolimie z okazji 3000-lecia Jerozolimy jako stolicy (1996). 4 (1996) 261-263

- Międzynarodowy Kongres Biblijny Starego Testamentu w Edynburgu. 6 (1975) 272-277

— XV Kongres IOSOT w Cambrigde (1995). 3 (1995) 214-217

- Przebudowa bazyliki Grobu św. bliska realizacji. 2 (1958) 114-123

— XVI Kongres Starego Testamentu (IOSOT) w Oslo (1998). 4 (1998) 292297

— Termin „posłani” w księdze Izajasza. 5 (1984) 387-393

- Tirsah, dawna stolica Izraela. Rzut oka na wykopaliska w Tell El-Far'ah (1946- 1955). 3 (1957) 213-218

- Wykopaliska z Mari a Stary Testament. 1 (1957) 9-23

- Wyposażenie duchowe Mesjasza według Iz 11, 1-5. 2 (1981) 88-97

WOJCIECHOWSKI Michał, Daty z życia Jezusa. 3 (1987) 202-214

- Dotknięcie trędowatego (Mk 1, 40-45). 5-6 (1984) 362-368

- Ewangelie jako biografie. 3 (1998) 168-180

- Język gestów w Starym Testamencie. 6 (1988) 504-517

— Od mitów do teologii („,Synowie boscy” z Rdz 6, 1-4). 4 (1988) 340-347

- Umycie nóg uczniom (J 13, 1-20). 3-6 (1990) 136-144

WOJTKOWSKI Julian bp, Colloquia Mediaevalia (1987). 6 (1987) 515

- Dogmat o Niepokalanym Poczęciu Najświętszej Maryi Panny w średniowiecznej literaturze polskiej. 1 (1953) 84-101

- Niepokalane poczęcie Najświętszej Maryi Panny w oficjach brewiarzowych i formularzach mszalnych Leonarda de Nogarolis i Bernardyna de Bustis. 2 (1954) 106-138

WOJTYŁA Karol kard., List do Przewodniczącego Sekcji Biblistów Polskich. 4-5 (1975) 146

- List z okazji 25-lecia RBL. 1 (1972) 1

— List z racji sympozjum „Biblia i Liturgia”. 2-3 (1971) 83

— Słowo wstępne. 2 (1966) 66

- W sprawie liturgii Wielkiej Soboty. 1 (1955) 40-47

WOLFF Jerzy ks., Czy Jezus był smutny? 6 (1958) 516-522 
WOLNIEWICZ Marian ks., Bezżeństwo dla królestwa Bożego (Mt 19, 10-12). 1 (1957) 23-34

- Biblijna działalność ks. Klawka w Wielkopolsce (1917-1923). 6 (1970) 266-276

- Ks. prof. Michał Peter (1922-1982). 1 (1983) 37-40

- Ks. prof. dr Witold Gronkowski. 5 (1964) 318-320

- Nauka o bezżeństwie i dziewictwie w Pierwszym liście św. Pawła do Koryntian. 3 (1958) 190-205

— Śp. ks. Felicjan Kłoniecki (1909-1990). 4-6 (1991) 151-153

WOLNY Jerzy ks., Udział polskiej teologii średniowiecznej w pracy duszpasterskiej Kościoła w Polsce. 2 (1966) 74-82

WOLSKI Józef, Wschód starożytny w świetle najnowszych badań. 2 (1952) 109-141; 3 (1952) 218-239

WORONOWSKI Franciszek ks., Grób św. Piotra (na podstawie wykopalisk). 1-3 (1956) 159-165

WRONKA Andrzej bp, 25 lat od wydania encykliki Piusa XII „Mediator Dei”. 6 (1972) 301-306

- Wprowadzenie do konstytucji „O liturgii” Soboru Watykańskiego II. 3 (1964) 138-146

WOŹNIAK Jerzy CM, Implikacje haj Jahwe. 2 (1980) 93-101

- Konferencja syriologiczna w Lejdzie (1985). 6 (1986) 497-498

- Znaczenie teologiczne wyrażenia „obrońca mój żyje” w Hi 19, 25. 1 (1984) 46-56

WÓJCICKI Krzysztof ks., Recytacje tekstów biblijnych. 1 (1978) 40-41

WÓJCIK Walenty ks., Wiatyk w średniowiecznym ustawodawstwie biskupów polskich. 1 (1953) 115-133

WÓJTOWICZ Joanna, Stopień znajomości słownictwa religijnego przez młodzież licealna.. 4 (1986) 362-365

WYCZAWSKI Hieronim Eugeniusz OFM, O właściwe imię błog. Władysława z Gielniowa. 3-4 (1961) 164-170

WYSZYŃSKI Stefan kard., List do Przewodniczącego Sekcji Biblistów Polskich. 4-5 (1975) 146

— Odpowiedź Prymasa Polski z dnia 6 II 1952 r. 6 (1983) 531-532

ZABORSKI Andrzej, Filolog i nauczyciel. 6 (1970) 293-297

- Nowe thumaczenie Biblii a teoria przekładu. 6 (1977) 296-310

- O recepcji metod strukturalnych w biblistyce. 2-3 (1973) 117-130 
ZAJĄCZKOWSKI Włodzimierz, Orientalistyka w uniwersytetach polskich. 3 (1951) 328

ZALEWSKI Stefan CSsR, Duchowość sakramentu bierzmowania. 1-2 (1975) 44-50

ZALEWSKI Zbigniew ks., Pobożność eucharystyczna, jej cechy i charakter. 4 (1986) 305-316

ZAŁĘSKI Jan ks., Nauka św. Pawła na temat małżeństwa w 1 Kor 7, 12b-13. 2 (1986) 108-111

Z archiwum liturgistów. Kilka myśli o ruchu liturgicznym (1951 r.). 6 (1983) 522-530

ZAWADZKI Józef ks., Jezusa Chrystusa „Kazanie na Górze” (Mt 5, 1-17; Łk 6, 2049). 1 (1949) 19-34; 2 (1949) 122-134

ZAWADZKI Roman Maria., Watykańskie kolekcje rękopisów św. Jana z Kęt. 5-6 (1973) 242-247

ZAWISZEWSKI Edward ks., Komentarz perykopy o Emmanuelu. 5 (1958) 384-403

— Księgi Kronik - apologia czy historia? 4-5 (1968) 233-237

- Nehemiasz poprzednikiem Ezdrasza. 6 (1969) 313-318

- Zagadnienia społeczne w prawodawstwie Starego Testamentu. 3 (1968) 139-146

ZDANOWICZ Stanisław ks., Zarys historyczny liturgicznego kultu św. Jadwigi. 1 (1953) 102-115

ZDZIARSTEK Roman OP, Chrystonomiczność egzystencji chrześcijańskiej według św. Pawła. 2 (1989) 98-110

Z działalności Polskiego Towarzystwa Teologicznego w Krakowie w roku 1983. 6 (1984) 505-510

ZEGZDA Marian SJ, Historia i problemy postu eucharystycznego. 1 (1955) 47-57

ZIELIŃSKA A[nastazja] J[anina] FMM, Odnowa liturgii w żeńskich wspólnotach zakonnych. 4-5 (1985) 355-371

ZIELIŃSKI Chwalisław, Co zleceniodawca powinien wiedzieć o malarstwie monumentalnym. 2 (1959) 184- 193

— Do kogo należą sprawy sztuki kościelnej? 3 (1959) 310-316

- Kościół i artysta. 5 (1962) 298-304

- Liturgia i sztuka a prawo kościelne. 5 (1960) 449-460

- Teologia a sztuka sakralna. 4 (1973) 200-204

ZIELNIOK Marian ks., Udział zakonu św. Benedykta w odnowie szat liturgicznych w XX wieku. 2 (1993) 64-72

ZIEMIAŃSKI Stanisław SJ, Udział ludu w śpiewie Proprium Missae. 1-2 (1968) 5559

ZIMOŃ Damian ks., Człowiek autorytetu. 6 (1983) 513-514 
- Eucharystia w kontekście duszpasterskim niedzieli. 1 (1981) 18-24

— Streszczenie dyskusji podczas sympozjum „Biblia i Liturgia”. 2-3 (1971) 148-150

ZIOŁO Piotr ks., Metaforyczność poezji hebrajskiej w ujęciu J. G. Herdera. 3 (1995) 193-199

ZIÓŁEK Władysław bp, Homilia wygłoszona podczas Mszy św. na rozpoczęcie sympozjum (Łódź 13 IX 1988 r.). 1 (1989) 61-63

ZIÓŁKOWSKI Zenon SDB, Esjon-Geber. 6 (1966) 377-381

- Najazd faraona Szeszonka I na Palestynę. 4-5 (1967) 219-226

- Starożytny Egipt a państwo Izrael. 6 (1967) 341-348

ZOLLI Eugeniusz, Uwagi do Psalmu 68. 1-3 (1956) 29-33

ZOŃ Andrzej OSB, Droga w Regule Wspólnoty. 4 (1963) 187-196

— Eklezjologiczny sens terminu „droga” w Dz 9, 2.4 (1964) 207-215

ZUZIAK Władysław ks., Europejska Federacja Uniwersytetów Katolickich (FUCE).

Na kanwie konferencji w Krakowie. 4 (1997) 293-295

ZWIĄZEK Jan ks., Argumentacja biblijna w kazaniach niedzielnych Mikołaja z Wilkowiecka. 4-5 (1969) 214-225

ŻARNOWIECKI Kazimierz ks., Chrystus w symbolach chrześcijańskich. 4 (1949) 253-271

- Odrodzenie życia liturgicznego we Francji. 3-4 (1950) 230-239

ŻELAZEK Józef ks., Liturgia i dziecko. 4 (1962) 222-231

- Rocznica chrztu św. 2 (1958) 153-158

ŻUREK Jacek ks., Środki audiowizualne a liturgia. 3 (1978) 154-157

ŻURAWSKI Franciszek ks., Ks. Karol Csesznak — twórczy praktyk posługiwania duszpasterskiego (W 100-lecie urodzin i 40. rocznic ę śmierci). 3 (1984) 242-246

- Zgromadzenie liturgiczne jako wydarzenie. 4 (1987) 359-362

ŻUROWSKA Felicja, Jałmużna bez reszty. 6 (1969) 357-361

- Łaska ostatniej godziny (Materiał do prowadzenia pogadanki ewangelicznej). 2 (1960) 153-162

- Miłosierdzie - nie ofiary! 5-6 (1963) 298-306

- Miłość błogosławiąca. 1-2 (1961) 62-67

- Miłość posługująca. 1 (1967) 40-47

- Odroczenie. 4 (1964) 243-248

- Płacz Chrystusa nad Jerozolimą. 1-2 (1968) 78-83

- Serce otwarte. 4 (1962) 232-240

— Śp. Dom Bernard Capelle OSB. 3 (1962) 187-190 
ŻYCHLIŃSKA Bernadetta s., Biblijna medytacja o Duchu Świętym. 3 (1998) 196-204 ŻYCIŃSKI Wojciech SDB, Przeklęte drzewo figowe - symbol czy legenda? (Mk 11, 12-14). 6 (1984) 483-493

\section{RECENZJE}

ABEL F. M., Histoire de la Palestine depuis la conquête d'Alexandre jusqu'e a l'invasion Arabe (ks. Kazimierz Borowicz). 3 (1952) 278

A Catholic Commentary on Holy Scripture (ks. Feliks Gryglewicz). 3-6 (1954) 233235

ADAM A., Das Kichenjahr mitfeiern (ks. Bogusław Nadolski TChr). 2 (1980) 111

ADAM A., Ernenerte Liturgie (ks. Wacław Świerzawski). 6 (1975) 297-298

ADAM A., Wo sich Gottes Volk versammelt (ks. Bogusław Nadolski TChr). 3 (1985) 263

ALBRIGHT W., Archeology and the Religion of Israel (ks. Stanisław Grzybek). 4-6 (1951) 435-440

ALBRIGHT W., Archeology of Palestine (ks. Feliks Gryglewicz). 6 (1949) 453-455

ALBRIGHT W., De l'âge de la pierre à la chriétenté (ks. Kazimierz Borowicz). 3 (1952) 277-278

de ALDAMA J. A., De quaestione mariali in hodierna vita Ecclesiae (o. Albert Urbański OC). 4-5 (1967) 297-300

ALLEGŔO J. M., The Dead Sea Scrolls (ks. Ludwik Stefaniak CM). 6 (1957) 498-500

ALONSO-SCHÖKEL L., Słowo natchnione (ks. Jerzy Chmiel). 2 (1985) 181-182

ALONSO-SCHÖKEL L., The Inspired Word (ks. Stanisław Mędala CM). 1 (1969) 4952

AMUSIN S. D., Nachodki u Martwogo Moria (Zdzislaw Kapera). 2 (1967) 123-126

Anamnesis (ks. Jerzy Chmiel). 2 (1997) 169

ANDET J. P., La Didache — Instructions des Apôtres (Tytus Górski). 1 (1959) 108109

ANONIMA, Dzieje pierwszej krucjaty albo czyny Franków i pielgrzymów jerozolimskich (ks. Jerzy Chmiel). 5 (1987) 461

ARENDT W. P., Bussakrament und Einzelbeichte (ks. Jerzy Stefański). 5 (1983) 467468

AUBERT R., La théologie catholique au milieu du XXe siècle (ks. Eugeniusz Florkowski). 4-5 (1955) 275-277

AUBRY A., de BACCIOCHI J., ROZIER C., Celebrations penitentielles (ks. Bogusław Nadolski TChr). 2-3 (1970) 159-160 
AUBRY A., Le temps de la liturgie est il passé? (ks. Bogusław Nadolski TChr). 6 (1968) 383-384

AYALA V., Z Maryją na modlitwie (ks. Adam Durak SDB). 4-6 (1991) 161

BAGATTI B., L'eglise de la Circoncision (ks. Aleksy Klawek). 2 (1967) 117-118

BALDI D., W ojczyznie Chrystusa. (ks. Jerzy Chmiel). 4 (1984) 368-369

BALY D., The Geography of the Bible (ks. Stanisław Grzybek). 1 (1958) 76-78

BAŃKA J., Biskup Teofil Bromboszcz (ks. Aleksy Klawek). 4-5 (1967) 308-309

BARDTKE J., Die Handschriftenfunde am Toten Meer (ks. Feliks Gryglewicz). 2 (1957) 167-168

BARTELT W., Hanbuch zur Schulbibel (ks. Józef Dajczak). 3 (1957) 223-225

BARTHÉLEMY D., MILIK J. T., Discoveries in the Judean Desert I (ks. Henryk Strakowski). 6 (1957) 482-485

BARTKOWSKI B., Polskie śpiewy religijne w żywej tradycji (Marian Fular). 1-3 (1991) 81-82

BARTNICKI R., Uczeń Jezusa jako głosiciel Ewangelii (ks. Stanisław Grzybek). 2 (1986) $174-175$

BAUER M., Aufänge der Christenheit von Jesus von Nazareth zur fruhchristlichen Kirche (ks. Edward Szymanek TChr). 1 (1972) 73-76

BAUER W., Wörterbuch zum Neuen Testament (ks. Ludwik Stefaniak CM). 2 (1955) $165-166$

BEA A., Le storicità dei Vangeli (ks. Zenon Ziółkowski SDB). 3 (1965) 185-191

BEASLEY MURRAY G. H., Baptism in the New Testament (ks. Ludwik Stefaniak CM). 5 (1965) 319-320

BECKER K. M., ROVIRA G., Aus den Menschen genomen (ks. Andrzej Fr. Dziuba). 5 (1981) 314-315

BECKER H., KACZYŃSKI R., Liturgie und Dichtung (ks. Wacław Świerzawski). 3 (1985) 259-262

BEDNARZ M., Zasłuchani w Słowo (ks. Jerzy Chmiel). 1 (1992) 47-48

BENOIT P., de VAUX R., Studia biblijne i archeologiczne (ks. Ludwik Stefaniak CM). 1 (1965) 56-58

BERGER K., Theologiegeschichte des Urchristentums (ks. Wiesław Alicki). 4 (1998) 319-320

BERNHARDT K. H., Der alte Libanon (ks. Jerzy Chmiel). 5 (1977) 281-282

BERTETTO B., Maria Immacolata (ks. Józef Litwin). 4-6 (1956) 316-318

BERTI C. M., CALABUIG J. M., Due progetti di canone eucharistico per il rito Romano nella luce ecumenica (ks. Aleksy Klawek). 6 (1966) 387-388

BESNARD A. M., Il vient toujours (ks. Stefan Koperek CR). 4 (1981) 253-254 
BESNARD A. M., La mystere du nom (ks. Aleksy Klawek). 1 (1964) 55-57

Beten mit der Kirche (ks. Andrzej Fr. Dziuba). 3 (1981) 191-192

BETZ O., RIESNER R., Jezus, Qumran i Watykan. Kulisy trzeciej bitwy o zwoje znad Morza Martwego (ks. Antoni Tronina). 1 (1997) 77

BEYERLIN W., Religionsgeschichtliches Textbuch zum Alten Testament (ks. Antoni Dreja). 3 (1981) 189-191

BIBBY G., Cztery tysiące lat temu (ks. Michał Peter). 4-5 (1967) 305-306

Bibel — Lexikon (ks. Stanisław Grzybek). 1 (1969) 47-49

Bibel und Kirche (Redakcja). 4 (1952) 376

Biblia księgą życia Ludu Bożego (ks. Stanisław Grzybek). 5 (1981) 315-318

Biblia to jest Pismo święte Starego i Nowego Testamentu z apokryfami (ks. Jerzy Chmiel). 1 (1992) 45

Biblia w dokumentach Kościoła (ks. Jerzy Chmiel). 3 (1997) 229-230

Biblia w nauczaniu chrześcijańskim (ks. Stanisław Grzybek). 1 (1993) 45-47

BISSOLI G. (red.), Giovani e Bibbia (ks. Ryszard Kempiak SDB). 1 (1992) 47

BLAISE A., Le vocabulaire latin des principaux liturgiques (ks. Stanisław Burzawa). 45 (1967) 314-315

BLIZNER J., Der Prozess Jesu (Irena Węsierska). 5-6 (1952) 488-492

BOGDAN Fr., Najmilsze pozdrowienie (o. Andrzej Krupa OFM). 4-5 (1971) 264-266

BOGUNIOWSKI J., Domus Ecclesiae (ks. Władysław Bomba CM). 1 (1989) 74-75

BOISMARD M. É., Le martyre de Jean l'apôtre (ks. Stanisław Mędala CM). 3 (1998) 241-242

BOLT D., Adam (Marian Fular). 1-3 (1991) 83

BOMBA W., Lectio brevis (ks. Tadeusz Matras). 2-6 (1992) 108-109

BONSIRVEN J., Le divorce dans le Nouveau Testament (ks. Stanisław Grzybek). 1-2 (1961) 74-77

BONSIRVEN J., Textes rabbiniques des deux premiérs siecles chriétens pour servir à l'intelligence du Nouveau Testament (ks. Tadeusz Szczurek). 3 (1957) 226-229

BORIG R.,. Der wahre Weinstock (ks. Feliks Gryglewicz). 4-5 (1968) 320-321

BORNKAMM J., Studien zum Neuen Testament (ks. Dominik Tomczyk SchP). 4 (1986) 368-369

BOROWSKI W., Psalmy. Komentarz biblijno-ascetyczny (ks. Jerzy Chmiel). 3 (1984) 277

BORRELLI A., de la FUENTE A., PUIG Ar., La Biblia i el Mediterrani (ks. Jerzy Chmiel). 4 (1997) 313 
Bóg. Dekalog. Błogosławieństwa. Modlitwa (ks. Stanisław Grzybek). 4 (1977) 225226

Bóg z nami (ks. Stanisław Grzybek). 6 (1972) 372

BOVER J. M., Novi Testamenti. Biblia graeca et latina (ks. Edward Harytym SJ). $1(1949) 68$

BOUYER L., La Bible et l'Evangile (ks. Ludwik Stefaniak CM). 4-5 (1955) 280-284

BRANDSTAETTER R., Jezus z Nazarethu (ks. Michał Peter). 6 (1967) 381-384

BRAULIK G., Deuteronomium II (ks. Józef Łach). 3-4 (1993) 191-192

Breviarum Romanum (ks. Tadeusz Szwagrzyk). 4 (1957) 349-350

BRIGHT J., Historia Izraela (ks. Julian Warzecha SAC). 4 (1994) 285

BRINKTRINE J., Msza święta (o. Paweł Sczaniecki OSB). 3 (1957) 233-238

BROWN R. E., The Community of the Beloved Disciple (ks. Stanisław Mędala CM). 3 (1981) 188-189

BROWN S., The Origins of Christianity (Michał Wojciechowski). 3 (1996) 207-209

BRUTSCHECK J., Die Maria — Marta — Erzählung (ks. Jerzy Chmiel). 3 (1995) 220-222

BRZEGOWY T., Księgi historyczne Starego Testamentu (ks. Stanisław Hałas SCJ). 1 (1997) 73-75

BRZEGOWY T., Prorocy Izraela (ks. Stanisław Grzybek). 3 (1994) 219-221

BUGNINI A., BRAGA C., Ordo hebdomadae Sancte Instauratus (o. Franciszek Małaczyński OSB). 2 (1958) 176

BUIS P., LECLERQ J., Le Deuteronome (ks. Kazimierz Borowicz). 2 (1964) 118-119

BUKOWSKI K., Biblia a literatura polska (Emil Biela). 6 (1985) 473-474

BUKOWSKI K., Słownik polskich Świętych (ks. Paweł Kowol). 2 (1995) 157-158

BUKOWSKI K., Święci polscy (ks. Paweł Kowol). 2 (1996) 140-141

BURCHARD Ch., Bibliographie zu den Handschriften vom Toten Meer. t. II (Zdzisław Kapera). 2 (1967) 121-123

BURROS M., More Lighton the Dead Sea Scrolls (ks. Eugeniusz Tomaszewski). 2 (1960) $179-180$

BURROS M., The Dead Sea Scrolls (ks. Henryk Strąkowski). 6 (1957) 485-488.

BUSS M. F. J., Die Missionspredigt des Apostels Paulus im Pisidischen Antiochien. (Dominik Tomczyk SchP). 5 (1984) 447-448

BUSSE H., Die Wunder des Propheten Jesus (ks. Tomasz Hergesel). 4 (1978) 225

CABIE R., La Penteĉote (ks. Stanisław Burzawa). 6 (1966) 384-385

Caeremoniale episcoporum (ks. Adam Durak SDB). 3 (1985) 263-264 
CALANDRA G., De historica Andreae Victorini expositione in Ecclesiastem (ks. Konrad Marklowski). 5 (1949) 375-376

Cantica Medi Aevi Polono-Latina (o. Paweł Sczaniecki OSB). 1 (1965) 61-62

CARMIGNAC J., La naissance des évangiles synoptiques (ks. Stanisław Mędala CM). 3 (1987) 263-264

CARMIGNAC J., Recherches sur le „Notre Père” — A l'ecoute du Notre Père (Zdzislaw Kapera). 3 (1974) 194-195

CARMIGNAC J., COTHENET E., LIGNÉE H., Les textes de Qumran (ks. Kazimierz Borowicz). 2 (1964) 124-125

CARMIGNAC J., GUILBERT P., Les textes de Qumran (ks. Kazimierz Borowicz). 2 (1964) 124-125

CARVAJAL F. F., Rozmowy z Bogiem (ks. Julian Warzecha SAC). 2 (1998) 151-152

CASEL O., Das christliche Opfermysterium (ks. Franciszek Woronowski). 1 (1970) 6162

CASSUTO M. D., Entzîglôpêdjahah Miqgrâîth (ks. Kazimierz Borowicz). 1 (1953) 219

Célèbrer la messe avec les enfants (ks. Stanisław Hartlieb). 2-3 (1977) 160-182

CERAM C. M., Bogowie, groby i uczeni (Tytus Górski). 3 (1959) 322-325

CERFAUX L., Le Christ dans la théologie de Saint Paul (ks. Eugeniusz Florkowski). 1 (1954) 58-59

CERFAUX L., TONDRIAN J., Le culte des souverains dans le civilisation grècoromaine (Tytus Górski). 2 (1959) 209-211

CHARLES F. J., Grammaire hebraique élementaire (o. Efrem Gliński OP). 3 (1949) 221-222

CHARPENTIER E., Czytając Stary Testament (ks. Antoni Dreja). 3 (1994) 217-219

CHAUVET L. M., Lignaggio e simbolo (ks. Jerzy Stefański). 4 (1983) 379-380

CHENU M. D., St. Thomas d'Aquin et la théologie (o. Bernard Przybylski OP). 4 (1959) 427-429

CHMIEL J., Homilie sakramentalne (ks. Kazimierz Panuś). 3 (1996) 216-218

CHMIEL J., Interpretacja Starego Testamentu w kerygmacie apostolskim o zmartwychwstaniu Jezusa (ks. Stanisław Grzybek). 4 (1980) 235-236

CHMIEL J., Lumière et charité d'après la première épitre de Saint Jean (ks. Stanisław Grzybek). 6 (1971) 334-336

CHMIEL J., Rozważania biblijne z Janem Pawłem II (ks. Kazimierz Bukowski). 2 (1986) 176

CHMIEL J., Z Chrystusem. Szkice homilii chrzcielnych, ślubnych i pogrzebowych (ks. Kazimierz Bukowski). 6 (1983) 554-555

CHMIELARSKI W., Życie Ewangelią (ks. Wojciech Pazera). 3 (1997) 232-234 
Chmury niewiedzy i listy (ks. Stanisław Urbański). 5 (1987) 461-462

CHOLEWIŃSKI A., Heiligkeitsgesetz und Deuteronomium (ks. Stanisław Łach). 5-6 (1976) 341-343

CHOLEWIŃSKI A., MOKRZYCKI B., Nabożeństwa biblijne (ks. Stanisław Grzybek). 6 (1968) 386-388

Chorał do modlitewników śląskich (ks. Władysław Kowalak SVD). 1-2 (1968) 123-128

Chorał opolski (o. Hugolin Langkammer OFM). 1-3 (1991) 82-83

Chronologia polska (o. Paweł Sczaniecki OSB). 3 (1959) 327-328

CHROSTOWSKI W., Prorok wobec dziejów (ks. Jerzy Chmiel). 4-6 (1991) 157

CIESZYŃSKI A., Bóg zbawia nas (ks. Stanisław Piątek). 6 (1972) 371-372

de CLERCK P., Zrozumieć liturgię (ks. Jan Janicki). 3 (1998) 242-244

COGGINS R. J., Introducing the Old Testament (Michał Wojciechowski). 1 (1995) 7274

Collectio Decretorum ad Sacram liturgiam spectantium ab anno 1927 ad annum 1946 (o. Franciszek Małaczyński OSB). 3 (1959) 325

Collectio Missarum de Maria Virgine (ks. Adam Durak SDB). 3 (1987) 266-267

Collectio théologhica, t. 36 (ks. Jan Kowalski). 1 (1967) 56-58

COLOMBO G., Introduzione allo studio della liturgia (ks. Adam Durak SDB). 4 (1989) 324-325

CONCETTI G., La Theologia dopo il Cincilio (ks. Stanisław Grzybek). 3 (1967) 190192

Concilium (ks. Jerzy Chmiel). 4-5 (1969) 308-312

CONGAR Y., La Mystère du temple ou l'économie de la présence de Dieu, a sa creat ure de Genèse à l'Apocalypse (ks. Marian Filipiak). 5 (1964) 331-332

CONTENAU G., La vie quotidienne à Babylone et en Assyrie (ks. Edward Haratym SJ). 4 (1952) 365-366

COOTE R. B., WHITELAM K. W., The Emergence of Early Israel in Historical Perspective (ks. Stanisław Mędala CM). 3-6 (1990) 173-174

Cor Salvatoris (ks. Michał Rękas). 3-4 (1954) 235-237

CORNELIUS I., The Iconography of the Caanite Gods Reshel and Ba' al. (Joachim Śliwa). 2 (1995) 152

Corpus christianorum (o. Dominik Michałowski OSB). 2 (1959) 203-204

de la CROIX P., Prièr les psaumes aujourd'hui (ks. Stefan Koperek CR). 4 (1983) 381

CROSS T. M., Ancient Library of Qumran and Modern Biblical Studies (Zdzisław Kapera). 2 (1965) 124-127 
CULlMANN O., Petrus. Jünger - Apostel - Märtyrer (ks. Eugeniusz Tomaszewski). 3-6 (1954) 220-227

CULLMANN O., La Tradition (ks. Szczepan Pieszczoch). 1 (1955) 65-68

Custodia di Terra Santa (A[leksy] K[lawek]). 1 (1952) 91

CZAJKOWSKI M., Biblia dziś odczytana. (ks. Julian Warzecha SAC). 6 (1990) 179190

CZAJKOWSKI M., Egzystencjalna lektura Biblii (ks. Julian Warzecha SAC). 2 (1995) 149-151

Cztery Ewangelie Pana naszego Jezusa Chrystusa. (ks. Aleksy Klawek). 1 (1966) 63-64

CZUJ J., Patrologia (ks. Wincenty Urban). 4-5 (1955) 267-270

DAJCZAK J., Katechetyka (ks. Władysław Wicher). 1 (1957) 73-74

DANIEL ROPS H., Das Volk Gottes (ks. Piotr Stach). 1 (1952) 88-90

DANIEL ROPS H., Histoire Sainte (ks. Stanisław Grzybek). 5-6 (1950) 375-376

DANIEL ROPS H., AMIOT P., Apokryfy Nowego Testamentu (ks. Władysław Smereka). 1 (1958) 78-80

DANIELOU J., Thèologie du judéo-christianisme (ks. Jan Łach). 3 (1959) 320-322

DANIELOU J., Thèologie de judéo-christianisme (ks. Stanisław Grzybek). 3-4 (1960) 379-381

DANILEWICZ J., Kościół i jego wnętrze w świetle przepisów prawno-liturgicznych (ks. Stanisław Szurek). 2 (1949) 143-144

DAVIES G. I., Ancient Hebrew Inscriptions (Marek Wodziński). 2 (1994) 132-133

DĄBEK T. M., „Nawracajcie się”. Metanoia w Nowym Testamencie (ks. Stanisław Grzybek). 4 (1996) 274-277

DĄBROWA E., Gangamela (ks. Jerzy Chmiel). 1-3 (1991) 83

DĄBROWSKI E., Dzieje Pawła z Tarsu (ks. Władysław Smereka). 2 (1948) 118-119

DĄBROWSKI E., Konkordancja podręczna do Pisma św. Nowego Testamentu (ks. Ludwik Stefaniak CM). 6 (1955) 374-375

DĄBROWSKI E., Pismo święte Nowego Testamentu (ks. Piotr Stach). 2 (1948) 105118

DĄBROWSKI E., Prolegomena do Nowego Testamentu (o. Augustyn Jankowski OSB). 1-2 (1961) 72-74

DĄBROWSKI E., Synopsa łacińsko-polska czterech Ewangelii (ks. Ludwik Stefaniak CM). 1-3 (1956) 174-180

DĄBROWSKI E., Święty Paweł — życie i pisma (ks. Piotr Stach). 3 (1951) 318-325

DEGENHARDT H. J., Lukas — Evangelist der Armen (ks. Michał Bednarz). 3 (1968) 195-196 
DEISSLER A., Das Alte Testament und die neuere katholische Exegese (ks. Aleksy Klawek). 4 (1965) 253-254

DEISSLER A., Die Grundbotschaft des Alten Testaments (ks. Stanisław Grzybek). 2-3 (1973) 165-167

DELLIUS W., Geschichte der Marienverehrung (o. Albert Urbański OC). 2 (1965) 118-119

DEMBSKA A., Kultura starożytnego Egiptu (ks. Jerzy Chmiel). 3 (1996) 216

DENIS A. M., Les thèmes de connaissance dans le Document de Damas (Zdzisław Kapera). 4-5 (1970) 248-251

Der Prozess gegen Jesus (ks. Jerzy Woźniak CM). 1 (1989) 79-80

DEUSSEU G., Die neue liturgische Gemeinde (ks. Bogusław Nadolski TChr). 2-3 (1969) 167-169

Die Bibel. Die Heilige Schrift des Alten und Neuen Bundes. (ks. Alfred Cholewiński SJ). 6 (1966) 386-387

DIEDERICH T., Das prophetische Berufsbewusstsein bei Jeremias (ks. Stanisław Sty ś SJ). 1 (1953) 208-210

Die katholische Kirche und das Judentum (ks. Bernard Wodecki SVD). 5 (1983) 471472

de DIETRICH S., Boży plan zbawienia (Redakcja). 4-5 (1967) 309-310

DIRKSEN P. B., The Transmission of the Text in the Peshitta (ks. Jerzy Woźniak CM). 4 (1986) 365-366

DISSEMOND F., Paulus und seine Zeit (ks. Jan Szlaga). 6 (1966) 385-386

DOBRACZYŃSKI J., Chrystus i Jego apostołowie (ks. Piotr Stach). 1 (1954) 47-56

DOBRACZYŃSKI J., Cień Ojca. (ks. Stanisław Grzybek). 5 (1977) 286-287

DOBRACZYŃSKI J., Manna i chleb (ks. Michał Peter). 2 (1955) 166-172

DOBRACZYŃSKI J., Pustynia (ks. Aleksy Klawek). 4-5 (1955) 270-275

DOBRACZYŃSKI J., Wybrańcy gwiazd (ks. Stanisław Grzybek). 3 (1949) 222-223

DROZD J., Ostatnia Wieczerza — Nowa Pascha (ks. Jerzy Chmiel). 6 (1978) 342

DRZYMAŁA K., Ks. Marcin Śmiglecki TJ. (ks. Jerzy Chmiel). 1 (1983) 62-63

DRZYMAŁA K., Ks. Stanisław Grodziski TJ (ks. Stanisław Grzybek). 2-3 (1973) 167168

DSCHULNIGE P., Sprache, Redaktion und Intention des Markus - Evangeliums (ks. Janusz Czerski). 2 (1987) 177-178

DUCHESNEAU C., La Celebration dans la vie chretienne (ks. Bogusław Nadolski TChr). 6 (1975) $298-299$

DUPONT J., CYN XRICTOI — L'union avec le Christ suivant Saint Paul (ks. Eugeniusz Florkowski). 3-6 (1954) 227-228 
DUPONT J., Mariage et Divorce dans l'Évangile Mt 19, 3-12 et paralleles (ks. Stan isław Grzybek). 3-4 (1961) 177-179

DUPONT-SOMMER A., Observations sur le Manuel de Discipline decouvert près de la Mer Morte (ks. Jan Łach). 6 (1967) 468-473

DUSSANT L., L'Éucharistie Pâques de toute la vie (ks. Jerzy Chmiel). 3 (1975) 143144

Dynamik im Wort (Dominik Tomczyk SchP). 6 (1985) 472-473

Działalność Instytutu ANTROPOS w dziedzinie lingwistyki, etnologii i religioznawstwa. (ks. Jerzy Chmiel). 6 (1981) 399-400

Dzieje Przymierza (ks. Stanisław Grzybek). 1 (1986) 79-80

DZIUBA A. F., Matka Boża z Guadelupe (ks. Stanisław Grzybek). 3 (1997) 230-232

EBELING G., Luther. Einfurhrung in sein Denken (o. Benedykt Sczaniecki OSB). 4 (1965) 249-250

EISSEFELDT O., Die Genesis der Genesis (Tytus Górski). 1 (1959) 106-110

Enchiridion biblicum (ks. Jan Augustynowicz). 1 (1955) 74-75

Enchiridion documentorum instaurationis liturgicae (ks. Władysław Nowak). 5 (1977) 283-284

ENGEL H., Die Vorfahren Israels in Ägypten (ks. Alfred Cholewiński SJ). 4 (1981) 247-249

Epitre de Saint Paul aux Romains (ks. Edward Szymanek TChr). 4-5 (1967) 317-319

Essential Papers on Messianic Movements and Personalities in Jewish History (Michał Galas). 4 (1994) 291-292

Évangile selon Marc (ks. Stanisław Włodarczyk). 6 (1978) 342

Ewangelia według św. Marka (ks. Stanisław Grzybek). 3 (1996) 214-215

FALSINI R., La Cresima sigillo della Spiritu (o. Franciszek Małaczyński OSB). 1-2 (1975) 88

FAVALE A., Il ministero presbiterale (ks. Adam Durak SDB). 1-3 (1991) 81

FAYNEL P., L'Église (ks. Adam Kubiś). 6 (1972) 366-367

FEDERICI T., Per conoscere Lui e la potenza della Resurrezione di Lui (ks. Adam Durak SDB). 1 (1989) 78-79; 3 (1987) 267-268

FENEBERG W., Der Markus prolog (ks. Tomasz Hergesel). 5-6 (1976) 331-332

FEUILLET A., Christologie paulinienne et tradition biblique (ks. Edward Szymanek TChr). 5-6 (1973) 338-340

FEUILLET A., La proloque du quatrième évangile (ks. Edward Szymanek TChr). 4-5 (1969) 304-308

Fides (Redakcja). 1 (1996) 69 
FILIPIAK M., Biblia o człowieku (ks. Stanisław Grzybek). 4 (1980) 233-234

FILIPIAK M., Człowiek współczesny a Stary Testament (ks. Jerzy Chmiel). 4 (1984) 363-365

FIONA V. R., Scarab Seals from a Middle to the Late Bronze Age Tomb at Pella in Jordan (Joachim Śliwa). 2 (1995) 152-153

FITZMYER J., Luke the theologian (Paweł Pietrusiak). 3-6 (1990) 176-177

FITZMYER J., 101 pytań o Qumran (Zenon Ziółkowski). 4 (1998) 321-323

FLEG E., Mojżesz w opowiadaniach mędrców (ks. Jerzy Chmiel). 3 (1994) 221

FOHRER G., Das Alte Testament (ks. Władysław Borowski CRL). 2-3 (1973) 158-159

FOKCIŃSKI H., Propozycje konsystorialne w XVI wieku (Redakcja). 4 (1994) 293294

Folia Orientalia, vol. XXIII (ks. Jerzy Chmiel). 6 (1987) 221

FORTMANN H., Vom bleibenden Sinn christlicher Feste (ks. Bogusław Nadolski TChr). 1 (1970) 62-63

FOURNIER E., L'Homilie selon la Constitution de la Sainte Liturgie (ks. Bogusław Nadolski TChr). 4-5 (1967) 311-313

FRANK M., Dieu a l'image de l'homme (ks. Konrad Marklowski). 4 (1952) 366-370

FRANKO I., Mojżesz (ks. Jerzy Chmiel). 3 (1994) 221

FREY A., Petite grammaire syriaque (ks. Jerzy Woźniak CM). 3 (1987) 263-264

FRIEDMAN R. E., Who Wrote the Bible (ks. Stanisław Mędala CM). 3-6 (1990) 172173

FRITSCH Ch. T., The Qumran Community (ks. Eugeniusz Sitarz CM). 6 (1957) 488490

le FROIS B., The woman clothed with the sun (Ap 12) individual ou collective? (ks. Ludwik Stefaniak CM). 1 (1955) 58-62

FROS H., SOWA F., Twoje imię (ks. Antoni Tronina). 5 (1977) 284-285

Frühchristliche Reden zur Osterzeit (ks. Wincenty Myszor). 1(1969) 47

FRYE N., The Great Code (ks. Jerzy Chmiel). 6 (1987) 546-547

GAĆ J., Moja Ziemia Święta (ks. Jerzy Chmiel). 4 (1994) 290

le GALL R., La liturgie, celebration de l'alliance (ks. Bogusław Nadolski TChr). 1 (1986) 83-84

GAMBER K., Liturgie übermorgen (ks. Jerzy Stefański). 2-3 (1969) 169-171

GARDEN E., Czy Biblia ma rację? (ks. Aleksy Klawek). 4-5 (1967) 315-316

GASTER T. H., The Dead Sea Scriptures in English Translation, with Introduction and Notes (ks. Eugeniusz Sitarz CM). 6 (1957) 490-491 
Geistliche Schriftlesung Erläuterungen zum Neuen Testament (ks. Aleksy Klawek). 4 (1965) 254-256

GELIN A., Les idées maîtresses de l'Ancien Testament (ks. Michał Peter). 2 (1952) 188-192

GELINEAU J., Dans vos assemblées (ks. Bogusław Nadolski TChr). 1 (1972) 77

GERRITZEN Ch., Lexikon der Bibel (ks. Józef Łach). 1-3 (1991) 78

GHIBERTI G., I racconti pasquali del cap. 20 di Giovanni confrontati con le altre tradizioni neotestamentarie (ks. Feliks Gryglewicz). 5-6 (1973) 341-342

GINSBERG H. L., Studies in Koheleth (ks. Kazimierz Borowicz). 4 (1952) 376

GIVEON R., Scarabas from Recent Excavations in Israel (Joachim Śliwa). 2 (1995) 153-154

GNILKA J., Das Evangelium nach Markus (o. Hugolin Langkammer OFM). 2 (1989) 135-136

GNILKA J., Der Epheserbrief (o. Hugolin Langkammer OFM). 2-3 (1973) 162-163

GNILKA J., Paulus von Tarsus Apostel und Zeuge (ks. Roman Pindel). 4 (1997) 311313

GOMA-CIVIT L., El Evangelio segun San Mateo 1-12 (ks. Jan Szlaga). 1 (1969) 52-53

GÓRSKI K., Od religijności do mistyki (o. Paweł Sczaniecki OSB). 4 (1963) 226-228

GOTETES R., Auswahlbibel fur katholische Schulen (ks. Aleksy Klawek). 4-5 (1966) 319-320

Gott ferien (ks. Andrzej Fr. Dziuba). 5 (1983) 468-469

Gott unser Heil (ks. Aleksy Klawek). 4-5 (1967) 316-317

Gottesdienst — Weg zur Einheit (ks. Leonard Górka SVD). 4-6 (1991) 159-160

GRABIANKA S., Drogi Chrystusowe (ks. Feliks Gryglewicz). 3 (1948) 191-192

GRAJKOWSKA L., Ks. Jakub Wujek z Wagrowca - Życie i działalność. (ks. Jerzy Chmiel). 3 (1997) 234

GRAMATOWSKI W., Polemika liturgiczna w Kongregacji Obrzędów (ks. Edward Sztafrowski). 2-3 (1992) 106-108

GRANDELAUDON M., Les livres des Maccabees (ks. Kazimierz Borowicz). 4 (1952) 372-373

GRELA K., Konkordancja Nowego Testamentu (ks. Jerzy Chmiel). 1 (1989) 80

GRELOT P., Sens chretien de l'Ancien Testament (o. Andrzej Zoń OSB). 2 (1964) $115-116$

GROER H. H., Litania loretańska (Marian Fular). 4 (1995) 302-303

GRUDNIOK Fr., „Która wiele umiłowała” (ks. Stanisław Grzybek). 2 (1996) 141-142

GRUDNIOK Fr., Pan idzie z nieba (ks. Stanisław Grzybek). 2 (1997) 166-167 
GRUDNIOK Fr., Skarb cierpienia (ks. Stanisław Grzybek). 2 (1994) 133-135

GRUDNIOK Fr., Z dnia na dzień (ks. Stanisław Grzybek). 3 (1998) 245-246

GRYGLEWICZ F., Archeologiczne odkrycia w egzegezie Nowego Testamentu (ks. Ryszard Karpiński). 1 (1963) 62-63

GRYGLEWICZ F., Błogosławiona przez wszystkie narody (ks. Jerzy Chmiel). 6 (1985) 469-470

GRYGLEWICZ F., Chleb, wino i Eucharystia w symbolice Nowego Testamentu (ks. Stanisław Grzybek). 6 (1968) 385-386

GRYGLEWICZ F., Ciało się stało (ks. Stanisław Grzybek). 1 (1976) 63-64

GRYGLEWICZ F., Chronologia życia Chrystusa Pana (ks. Ludwik Stefaniak CM). 4 (1958) 360-363

GRYGLEWICZ F., Ewangelia według św. Łukasza (ks. Stanisław Grzybek). 5-6 (1976) 335-337

GRYGLEWICZ F. (red.), Egzegeza Ewangelii św. Jana (ks. Jan Szlaga). 5 (1977) 282283

GRYGLEWICZ F., Studia z teologii św. Łukasza (ks. Ryszard Rubinkiewicz SDB). 56 (1976) 333-335

GRZEŚKOWIAK J., Liturgia dziś (Elżbieta Miziołek). 4 (1983) 281-282

GRZYBEK St., „Przygotujcie drogę Panu, Jemu prostujcie ścieżki” (Mt 3, 3) (ks. Wojciech Pazera). 3- 6 (1990) 180-181

GRZYBEK St., „,Wierzcie w Ewangelię” (Mk 1, 15) (Marian Fular). 1 (1985) 83-84

GRZYBEK St., CZERWIEŃ B., PANASIUK B., Polska bibliografia biblijna za lata 1931-1965 (ks. Ludwik Stefaniak CM). 2-3 (1970) 156

GUILLET J., Thèmes bibliques (ks. Michał Peter). 4-6 (1956) 320-327

GÜNTHER J. J., St. Paul's Opponents and Their Background (ks. Stanisław Mędala CM). 5-6 (1976) 337-339

HAAG H., Biblische Schoepfungalehre und kirchliche Erbsündenlehre (ks. Aleksy Klawek). 2 (1967) 118-119

Hagiografia polska (ks. Henryk Weryński). 4 (1973) 238-239

HAINZ J., Koinonia (o. Tomasz M. Dąbek OSB). 1 (1985) 76-77

HALTER H., Taufe und Ethos (ks. Andrzej Fr. Dziuba). 2-3 (1979) 172-173

HAŁAS St., L'interpretazione della Risurrezione e dei suoi effetti (ks. Jerzy Chmiel). 4 (1996) 277-278

HAŁAS St., Zmartwychwstanie Chrystusa w życiu chrześcijanina (ks. Tadeusz Matras). 1 (1993) 50

HAMMAN A., Vie liturgique et vie sociale (ks. Bogusław Nadolski TChr). 6 (1972) 370-371 
Handbuch der Verkündigung (ks. Wacław Świerzawski). 6 (1975) 295-296

HARING B., Nauka Chrystusa. Teologia moralna (ks. Władysław Wicher). 4 (1964) 258-259

HARRINGTON W. J., Klucz do Biblii (ks. Stanisław Grzybek). 1 (1983) 56-58

HARRISON R. K., Archeology of the Old Testament (Zdzisław Kapera). 1 (1965) 5960

HARRISON R. K., The Dead Sea Scrolls (Zdzisław Kapera). 2 (1964) 122-124

HAYEK M., Liturgie maronite - histoire et textes eucharistiques (ks. Stanisław Burzawa). 4-5 (1967) 307-308

HEIDEL A., The Babylonion Genesis (ks. Kazimierz Borowicz). 3 (1952) 276-277

HEINISCH P., Geschichte des Alten Testament (ks. Kazimierz Borowicz). 3 (1952) 276-277

HEINZ A, RENNINGS H., Heute segnen (ks. Bogusław Nadolski TChr). 2 (1993) 109-110

HENGSBACH F., Ich, der Mitälteste (ks. Stanisław Grzybek). 5-6 (1989) 401-403

HENNECKE E., Neutestamentliche Apokryphen (o. Hugolin Langkammer OFM). 4-5 (1968) 317-320

HENNECKE E., Neutestamentliche Apokryphen in deutscher Übersetzung (Tytus Górski). 5 (1962) 317-319

HESCHEL A. J., Szabat i jego znaczenie dla współczesnego człowieka (ks. Jerzy Chmiel). 4 (1994) 291

HENTSCHEL G., Die Elija — erzählungen (ks. Józef Łach). 5 (1978) 279-280

HICK L., Stellung des hl. Paulus zur Frau im Rahmen seiner Zeit (ks. Sylwester Baksik). 2 (1956) 174-175

S. HIERONIMI Presbyteri, Opera pars I (o. Paweł Sczaniecki OSB). 4 (1959) 429-432

HŁADOWSKI W., Początki chrześcijaństwa według egzystencjalenej interpretacji R. Bultmanna (ks. Ludwik Stefaniak CM). 3-6 (1954) 237-238

HOLZNER J., Autor de Saint Paul (ks. Stanisław Grzybek). 5 (1958) 462-463

HORNUNG E., Eschaton (Joachim Śliwa). 2 (1995) 151-152

HUBY J., Mistiques Paulinienne et Johannique (ks. Stanisław Smoleński). 1 (1953) 219-220

HUPPERT U., Izrael. Rabini i heretycy (ks. Jerzy Chmiel). 2 (1994) 151-152

HURTH F., ABELLAN P. M., De Sacramentis (ks. Władysław Wicher). 1 (1953) 219220

Idee przewodnie soborowej konstytucji „O Bożym Objawieniu” (ks. Michał Czajkowski). 4-5 (1970) 251-256 
Idee przewodnie soborowej konstytucji „O Kosciele” (ks. Stanisław Grzybek). 2-3 (1971) 156-160

van IMSCHOOT P., Théologie de l'Ancien Testament (ks. Stanisław Grzybek). 4-6 (1956) 312-316

INNITZER T., Komentar zur Leidens und Verklarungs-geschichte Jesu Christi (Redakcja). 3 (1949) 224

Instytut Teologiczny w służbie diecezji częstochowskiej (ks. Tadeusz Matras). 1 (1993) 49

ISNERI J., Expositio Missae. M. Zahajkiewicz, Msza św. w Polsce przed Soborem Trydenckim w świetle rodzimych komentarzy (ks. Roman Nir). 1 (1973) 53-54

Izrael (ks. Jerzy Chmiel). 4 (1994) 49

JACKOWSKI A., Zarys geografii pielgrzymek (ks. Jerzy Chmiel). 4-6 (1991) 161-162

JACOB E., Théologie de l'Ancien Testament (o. Juliusz Synowiec OFMConv). 2-3 (1969) 171-173

JAKUBIEC C., Ksiegga Hioba (ks. Stanisław Grzybek). 6 (1974) 355-356

JAKUBIEC C., Wprowadzenie do ksiąg Starego Testamentu (ks. Aleksy Klawek). 3-6 (1954) 239-240

JAKUBIEC C., Wstęp ogólny do Pisma świętego (ks. Aleksy Klawek). 1-3 (1956) 173174

JANKOWSKI A., Biblijna teologia przymierza. (ks. Jerzy Chmiel). 6 (1987) 541-542

JANKOWSKI A., Duch Dokonawca (ks. Jerzy Chmiel). 6 (1985) 465-466

JANKOWSKI A., Królestwo Boże w przypowieściach (ks. Jan Pytel). 1 (1983) 58-60

JANKOWSKI A., Listy więzienne świętego Pawła (ks. Kazimierz Romaniuk). 2-3 (1963) 153-157

JANKOWSKI A., Zarys pneumatologii Nowego Testamentu (ks. Jerzy Chmiel). 2 (1984) 184-185

JANKOWSKI A., Z rozważań nad Nowym Przymierzem (ks. Władysław Smereka). 3 (1962) 191-195

JANKOWSKI A., ROMANIUK K., Kapłaństwo w Piśmie świętym Nowego Testamentu (ks. Jerzy Chmiel). 1 (1973) 55

JANKOWSKI St., Przewodnik po Ziemi Świętej (ks. Edward Szymanek TChr). 3 (1984) 280-281

JANÓW J., Najstarsze szczątki ewangeliarza polskiego (ks. Aleksy Klawek). 3-4 (1950) 248

JAROŠ K., Hundert Inschriften aus Kanaan und Israel fur den Hebräischunterricht bearbeitet (ks. Jerzy Woźniak CM). 3 (1987) 263 
Jedynemu Bogu. Modlitewnik archidiecezji gnieźnieńskiej (o. Franciszek Małaczyński OSB). 2 (1959) 213-215

JELITO J., Historia czasów Starego Testamentu (ks. Michał Peter). 2 (1962) 129-132

JELONEK T., Biblijna historia zbawienia (ks. Tomasz Zaklukiewicz). 2 (1989) 151152

JEREMIAS J., Unbekannte Jesus worte (ks. Tadeusz Szczurek). 6 (1958) 567-569

JERGER G., „Evangelium des Alten Testaments” (ks. Jerzy Chmiel). 6 (1987) 546

JĘDRZEJEWSKI S., U korzeni zła (ks. Andrzej Kondracki SDB). 3 (1997) 77-78

JOHNSON S., The Theology of the Gospels (ks. Ryszard Rubinkiewicz SDB). 1 (1969) 55-56; 2-3 (1969) 173-175

JONGELING B., CLASSIFIED A., Bibliography of the Finds in the Desert of Judah 1958-1969 (Zdzisław Kapera). 2-3 (1973) 159-160

JOUNEL P., La Messe hier et aujourd' hui (ks. Andrzej Fr. Dziuba). 1 (1989) 77-78

JUNGMANN J. A., Liturgie der christlichen Frühzeit (ks. Wincenty Myszor). 1 (1969) 44-47

KACZMAREK L., Zarys psychologii neotomistycznej (ks. Zygmunt Szmigiel). $6(1958) 576$

KAHLEFELD A., Der Jünger (ks. Feliks Gryglewicz). 5-6 (1963) 322

Kalendarz żydowski (ks. Stanisław Pisarek). 6 (1985) 474

KALINOWSKI Z., Rozważania o św. Józefie (ks. Stanisław Rumiński). 3 (1981) 192

KANTOR M., Struktury dośrodkowe i odśrodkowe w poezji biblijnej (ks. Sylwester Jędrzejewski SDB). 3 (1998) 238-239

KAROL A., Jezuita romantyczny o. Maksymilian Ryłło (Joachim Śliwa) 2 (1995) 156157

Katholischer Katechismus der Bistümer Deutschlands (ks. Józef Dajczak). 6 (1955) 377-385

KELLER W., A jednak Pismo święte ma racje (Jan Desperak). 6 (1959) 601-603

KELLERMANN M., MĘDALA S., PICCIRIILLO M., SITARZ E., Welt aus der die Bibel kommt (ks. Jerzy Woźniak CM). 5 (1983) 469-471

KELLY P. H., Biblical Hebrew (Maria Kantor). 1 (1994) 66

KIEFFER R., Foi et justification á Antioche (o. Tomasz M. Dąbek OSB). 2 (1984) $185-186$

KINDER E., Der evangelische Glaube und die Kirche (ks. Kazimierz Hoffmann). 1 (1962) 61-63

KING A., Liturgie d' Antioche: La rite syrien et rite chaldéen (ks. Stanisław Burzawa). 4-5 (1967) 306-307 
KITTEL G., Theologisches Wörterbuch zum Neuen Testament (ks. Ludwik Stefaniak CM). 4 (1957) 351

KITTEL G., FRIEDRICH G., Theologisches Wörterbuch zum Neuen Testament, t. VI (ks. Ludwik Stefaniak CM). 2 (1960) 177-179

KITTEL G., FRIEDRICH G., Teologisches Wörterbuch zum Neuen Testament, t. VII (ks. Ludwik Stefaniak CM). 2 (1965) 114-115

KITTEL G., FRIEDRICH G., Teologisches Wörterbuch zum Neuen Testament, t. VIII (ks. Ludwik Stefaniak CM). 1 (1972) 69

KITZINGER E., Mosaïques byzantines israélienes (ks. Michał Peter). 3 (1968) 196

KLAWEK A., Onomastyka biblijna (ks. Stanisław Grzybek). 4 (1962) 256

KLUGMAN H., Polonica w Ziemi Świętej (ks. Jerzy Chmiel). 4 (1994) 291

KŁONIECKI F., Co sądzić o raju biblijnym? (ks. Michał Peter). 1 (1952) 91-94

KNOCH O., Begegnung wird Zeugnis (Dominik Tomczyk SchP). 3 (1984) 273-279

KNOCH O., Wer Ohren hat der höre (Dominik Tomczyk SchP). 1 (1985) 75-76

KOLAK W., Klasztor Augustianów przy kościele św. Katarzyny w Krakowie (ks. Jan Kuś). 4 (1983) 376-379

KOLBUSZEWSKI J., Wiersze z cmentarza (ks. Jerzy Chmiel). 2 (1987) 180-181

KOMISJA DUSZPASTERSKA EPISKOPATU POLSKI, Jezus Chrystus jedyny Zbawiciel świata (ks. Jerzy Chmiel). 4 (1996) 283

KOPP J. V., Entstelung und Zukunft des Menschen (ks. Aleksy Klawek). 2 (1967) 119120

KOPEREK S., Teologia roku liturgicznego (ks. Andrzej Korpusik). 1 (1985) 78-79

KORNFELD W., Das Buch Leviticus (ks. Stanisław Grzybek). 5-6 (1973) 330-331

KOSIDOWSKI Z., Gdy słońce było bogiem (Zygmunt Wawszczak). 4 (1957) 348-349

KOSTECKI R., Boże Macierzyństwo Najświętszej Maryi Panny (o. Ireneusz Łuczyński OP). 3-4 (1960) 374-375

KOSTECKI R., Świętość Chrystusa głowy Ciała Mistycznego (ks. Eugeniusz Sitarz CM). 1 (1957) 74-80

KOTLARCZYK M., Sztuka żywego słowa (ks. Jerzy Chmiel). 5-6 (1976) 344

KOŚCIAŁOWSKI S., Maksymilian Ryłło TJ (Włodzimierz Zajączkowski). 1 (1949) 69-70

Kościół w świetle Biblii (ks. Jerzy Chmiel). 5 (1987) 450

KOTT J., Zjadanie bogów (ks. Jerzy Chmiel). 4 (1989) 321-322

KRAWCZUK A., Król Herod Judei (ks. Aleksy Klawek). 5 (1965) 317-319

KRAWCZYK R., Sprawy ludzkie w Biblii (Wiesława Horst). 6 (1987) 547-548 
KRAUS J. H., Geschichte der historisch — kritichen Erforschung des Alten Testament (Tytus Górski). 1 (1962) 59-61

KREMER J., Lazarus (ks. Janusz Czerski). 2 (1987) 179-180

KRINETZKI L., Der Bund Gottes mit den Menschen nach dem Alten und Neuen Testament (ks. Ludwik Stefaniak CM). 1 (1965) 62-63

Książki nadesłane do Redakcji (ks. M[iłosław] K[ołodziejczyk]). 3-4 (1961) 179-180; 5 (1961) 272

Księga imion i Świętych (ks. Jerzy Chmiel). 2 (1997) 168-169; 3 (1998) 246

KUDASIEWICZ J., Biblia — historia — nauka (ks. Stanisław Grzybek). 5 (1979) 285$288 ; 3$ (1987) 268-270

KUDASIEWICZ J., Duch Święty w życiu chrześcijańskim (ks. Grzegorz Łopatka). 2 (1998) 154

KUDASIEWICZ J., Jezus historii a Jezus wiary (ks. Stanisław Grzybek). 5 (1987) 451452

KUDROŃ C., Bliżej nieba (ks. Stanisław Grzybek). 1 (1976) 60-62

KUDROŃ C., Nadzieją mocni (ks. Stanisław Grzybek). 1 (1976) 62-63

KUDROŃ C., Stał się człowiekiem (ks. Stanisław Grzybek). 1 (1976) 62

KUDROŃ C., Trwajcie we Mnie (ks. Stanisław Grzybek). 4 (1977) 225

KUGEL J. L., The Idea of Biblical Poetry (ks. Jerzy Chmiel). 5 (1987) 456-457

KULISZ J., Jezus w historii (ks. Janusz Królikowski). 1-3 (1991) 80-81

KUSHNER H. S., Kiedy złe rzeczy zdarzają się dobrym ludziom (ks. Stanisław Grzybek). 1 (1994) 64-65

KWIATKOWSKI W., Apologetyka totalna (ks. Szczepan Szydelski). 4-5 (1955) 255267

La Bible de Jérusalem (Dariusz Długosz). 4 (1998) 316-318

LABUDA A., Liturgia pogrzebu do wydania Rytuału Piotrkowskiego (ks. Jan Kracik). 1 (1985) 80-81

La confirmation (ks. Czesław Krakowiak). 1-2 (1975) 86

La liturgie aprés Vatican II (ks. Stanisław Burzawa). 4-5 (1968) 321-322

LANCELLOTI A., Gramatica accadia (ks. Aleksy Klawek). 2 (1965) 112-114

LANCZKOWSKI G., Wprowadzenie do religioznawstwa (ks. Jerzy Chmiel). 5 (1987) 457-458

LANG B., Ein Buch wie kein auderes (Dominik Tomczyk SchP). 3 (1984) 278

LANGE G., Kunst zur Bibel (ks. Jerzy Chmiel). 1-3 (1991) 80

LANGKAMMER H., Apokryfy Nowego Testamentu (Jolanta Włodarczyk). 3-6 (1990) 178-179 
LANGKAMMER H., Biblijne podstawy duchowości chrześcijańskiej (o. Marian Arndt OFM). 1 (1989) 149-151

LANGKAMMER H., Etyka Nowego Testamentu (ks. Janusz Czerski). 4 (1986) 367368

LANGKAMMER H., Ewangelia według św. Marka (ks. Jerzy Chmiel). 6 (1978) 339340

LANGKAMMER H., Hymny chrystologiczne Nowego Testamentu (ks. Jerzy Chmiel). 5-6 (1976) 343-344

LANGKAMMER H., Księgi Ezdrasza i Nehemiasza (ks. Stanisław Grzybek). 2-3 (1973) 164-165

LANGKAMMER H., Słownik biblijny (ks. Antoni Tronina). 1 (1983) 60-61

LANGKAMMER H., Teologia Nowego Testamentu (ks. Jerzy Chmiel). 1 (1992) 4647; (Dominik Tomczyk SchP). 6 (1985) 471-472

LANGKAMMER H., Wprowadzenie do ksiąg Nowego Testamentu (ks. Jerzy Chmiel). 2 (1981) 134-135

LANGKAMMER H., Wprowadzenie i komentarz do ewangelicznych opisów Męki Pańskiej (ks. Jerzy Chmiel). 5-6 (1976) 340

La nuova proposta di iniziazione alla vita cristiana (ks. Jerzy Stefański). 1 (1986) 82-83

LÄPPLE A., Od egzegezy do katechezy (ks. Stanisław Pisarek). 2 (1987) 172-175

La prédication en Pays d'Oc. (ks. Kazimierz Panuś). 4 (1998) 323-325

La Sainte Biblie traduite en français (ks. Stanisław Grzybek). 1-3 (1956) 171-173

LASOR W. S., Bibliography of the Dead Sea Scrolls (Zdzisław Kapera). 2 (1964) 121122

La Terra Sainte (ks. Aleksy Klawek). 6 (1964) 362-363

LATOURELLE R., L'accès à Jesus par Évangiles histoire et herméneutique (ks. Eug eniusz Florkowski). 3 (1980) 179-180

LATOURELLE R., Le Christ et l'Église signes du salut (ks. Adam Kubiś). 1 (1972) 78-79

de LAUGHE R., Le textes de Ras Shamra - Ugarit et Leurs rapports avec le Milieu biblique de l'Ancient Testament (ks. Edward Haratym SJ). 5-6 (1948) 359-360

LAURENTIN R., Les Évangiles de l'Enfance du Christ (ks. Teofil Siudy). 6 (1985) 466-468

LAZZARATO D., Chronologia Christi seu Discordantium Fontium Concordantio ad juris normam (ks. Jan Drozd SDS). 3-6 (1954) 228-233

LECMHNIS F., KLIJN A., van GELDER G., The Arabie Text of the Apocalypse of Baruch (ks. Jerzy Woźniak CM). 2 (1989) 152-153 
LEFEBVRE G., Notre participation au drame de la Redemption per la Liturgie (ks. Wacław Świerzawski). 5 (1962) 319-320

LEHNER M., HASLERS A. B., Neues Denken in der Kirche (ks. Franciszek Woronowski). 2-3 (1969) 177-179

LEIPOLDT J., GRUNDMANN W., Umwelt des Urchristentums (ks. Jan Drozd SDS). 6 (1969) 379-380

LEMAIRE A., Dzieje biblijnego Izraela (ks. Julian Warzecha SAC). 4 (1998) 318-319

LENCZEWSKI M., Liturgika (ks. Leonard Górka SVD). 5 (1977) 288-289

LENGELING E. J., Kritische Bilanz (ks. Bogusław Nadolski TChr). 5 (1977) 285-286

LÉON-DUFOUR X., Dictionnaire du Nouveau Testament (ks. Jerzy Chmiel). 1 (1978) 55

LÉON-DUFOUR X., Les Évangiles et l'histoire de Jésus (ks. Jerzy Chmiel). 2 (1964) 120

LEON WIELKI św., Mowy (o. Paweł Sczaniecki OSB). 4 (1958) 355-356

Le Testament Grec d' Abraham (ks. Marian Wittlieb). 4 (1989) 314-315

LEWASZKIEWICZ T., Łużyckie przekłady Biblii (Rafał Leszczyński). 2 (1996) 136137

LEWELS M., Was sagt der hebräische Text? (ks. Sylwester Baksik). 6 (1955) 376-377

LIEBES J., Studies in the 20 har Studies in Jewish Myth and Jewish Messianism (Michał Galas). 4 (1994) 292-293

List of Old Testament Peshitta Manuscripts (ks. Jerzy Woźniak CM). 2 (1986) 173

Liturgia horarum (ks. Jerzy Durak SDB). 4 (1986) 369-370

LIWSZYC G. M., Proischoždenie christianstwa v svete rukopisej Mertvego Morja (Zdzisław Kapera). 4-5 (1971) 266-270

LODS A., Histoire de la littérature hébreique et juive depuis les origines jusqu'à la riune de l'état juif (ks. Kazimierz Borowicz). 4 (1952) 371-372

LOHFINK G., Rozumieć Biblię (ks. Stanisław Grzybek). 6 (1987) 542-544

LOHFINK G., PESCH R., Triefeupsychologie und keine Exegese (ks. Jan Łach). 3 (1988) 270-271

LOHFINK N., Unsere grossen Feste (ks. Bogusław Nadolski TChr). 6 (1985) 474-475

LOHSE E., Die Texte ans Qumran (ks. Ludwik Stefaniak CM). 2 (1965) 120

LÖNING K., Die Saulustradition in der Apostolgeschichte (ks. Feliks Gryglewicz). 5-6 (1973) 340-341

le LORENZI L., Romani. Vivere nello Spiritu in Cristo (o. Tomasz M. Dąbek OSB). 1 (1985) 77-78

LURKER M., Słownik obrazów i symboli biblijnych (Jacek Stryczek). 3 (1990) 170171 
LUDEMANN G., SCHRÖDER M., Die Religionsgeschichtliche Schule in Göttingen (ks. Jerzy Chmiel). 4 (1989) 321

ŁACH J., Jezus syn Dawida (ks. Stanisław Grzybek). 5-6 (1973) 337-338

ŁACH J., Z myślą o rodzinie (ks. Stanisław Grzybek). 1 (1996) 67-68

ŁACH St., Księga Kapłańska - Liczb - Powtórzonego Prawa (o. Hugolin Langkammer OFM). 1 (1972) 69-73

ŁACH St., Rozwój ofiar w religii starotestamentalnej (ks. Jan Szlaga). 4-5 (1971) 256257

ŁACINA J., Słownik arabsko-polski (ks. Jerzy Chmiel). 3 (1997) 228-229

ŁUBIŃSKA E. A., Salamandra (Marian Fular). 2 (1987) 181-182

MAAS-EWERD Th., Liturgie und Pharrei (ks. Stefan Koperek CR). 6 (1972) 369-370

MAJANI Z., Szalom - żydowskie dla początkujących (ks. Zbigniew Kaznowski). 3-6 (1954) 238-239

MAŁUNOWICZ L., Podręcznik łaciny kościelnej (Tytus Górski). 4-5 (1955) 285-287

MAŁUNOWICZ L., Roma Christiana - Podręcznik do łaciny chrześcijańskiej (Tytus Górski). 3 (1962) 195-196

MANTEUFFEL J., Ze świata papirusów (ks. Feliks Gryglewicz). 3 (1951) 325-326

Manuscriptum Gertrudie (o. Paweł Sczaniecki OSB). 2 (1960) 183-185

MARCHADOUR A., Lazare (o. Tomasz M. Dąbek OSB). 1 (1989) 76-77

MARCHEL W., Abba, Père! La prière du Christ et des chrétiens (ks. Michał Czajkowski). 3-4 (1961) 175-176

MARCHEL W., Abba Père! (ks. Jerzy Chmiel). 1 (1972) 76

MARCHEL W., Abba, Vater! Die Vaterbotschaft des Neuen Testament (ks. Ludwik Stefaniak CM). 1 (1965) 58-59

MAREK Zb., Biblia w katechetycznej posłudze Słowa (ks. Grzegorz Łopatka). 2 (1998) 155

MARIANI B., Introductio in libros sacros Veteris Testamenti (ks. Stanisław Grzybek). 3 (1959) 326-327

MARIE-ALINE de Sion, La fotesse Antonia á Jerusalem et question du prétoire (ks. Kazimierz Barcki). 3 (1957) 221

MARTENS H. A., Hanbuch der Bibelkunde (ks. Julian Sulowski SJ). 1-2 (1968) 115117

MASSAUX E., Influence de l'Évangile de Saint Matthieu (Tytus Górski). 3 (1951) 327

Materiały pomocnicze do wykładów z biblistyki (ks. Jan Szlaga). 1 (1976) 58-59

MATTHIE K., THIEL W., Biblische Zeittaflen (ks. Dominik Tomczyk SchP). 2 (1987) $176-177$ 
MATURA M. C., La qahal et son contexte cultuel (ks. Stanisław Grzybek). 5 (1964) 330-331

MATURA T., La Radicalisme Évangélique aux sources dela vie chrétienne (ks. Teofil Herrmann CM). 4 (1961) 254-255

MAURIS E., Le travail de l'homme et son oeuvre (ks. Feliks Gryglewicz). 1 (1952) 95-96

MAYES A. D. A., Israel in the period of the Judges (ks. Stanisław Grzybek). 2 (1978) 115-116

MAZZOLENI A., La parrocchia (ks. Franciszek Woronowski). 6 (1972) 367-368

del MEDICO H. E., L'Énigme des manusrits de la Mer Morte (ks. Eugeniusz Sitarz CM). 6 (1957) 496-498

MEISSINGER K. A., Der katholische Luther (ks. Kazimierz Hoffmann). 2 (1967) 126128

de MELLO A., Przebudzenie (ks. Jerzy Chmiel). 1 (1993) 50-51

MENESCHG H., Die Erzählung von der ehernen Schlauge (Num 21, 4-9) in der Auslegung der fruhen judischen Literatur (ks. Bogdan Poniży). 3 (1988) 267-268

MERTON Th., La pain vivant (Zofia Włodkowa). 3-4 (1960) 370 -372

Il messaggio della salvezza (ks. Zenon Ziółkowski SDB). 1 (1967) 60-63

MESTERS C., Boże, gdzie jesteś? (ks. Stanisław Grzybek). 3 (1978) 171-172

MĘDALA St., Chrystologia Ewangelii św. Jana (o. Augustyn Jankowski OSB). 1 (1994) 62-63

MEDALA St., Parabola oleastri (ks. Jan Stępień). 2-3 (1973) 160-162

MICHAELIS W., Die Apokryphen Schriften zum Neuen Testament (ks. Tadeusz Szczurek). 3 (1957) 226

MICHAŁOWSKI K., Opera minora (ks. Jerzy Chmiel). 4-6 (1991) 157-158

MICHEL A., Lè Maître de Justice d'après les documentes de la Mer Morte, la litterature apocryphe et rabbinique (ks. Henryk Strąkowski). 6 (1957) 476-478

MICHIELS Al., Index verborum omnium sunt in Tertulliani tractatu de praescriptione haereticorum (o. Paweł Sczaniecki OSB). 6 (1959) 603-604

Miejsca święte (o. Franciszek Małaczyński OSB). 4 (1998) 325-326

MILIK J. T., Dix ans de découvertes dans le Désert de Juda (ks. Eugeniusz Sitarz CM). 6 (1957) 491-496

MILLER J. M., HAYES J. H., A History of Ancient Israel and Judah (Michał Wojci echowski). 1 (1993) 47-49

MILLER J. M., TUCHER G. M., The Book of Joshua (s. Emilia Ehrlich OSU). $6(1975) 295$ 
Minette de Tillesse. Le secret messianique dans l'Évangile de Marc (ks. Jan Łach). 4-5 (1970) 246-248

Ministrant światła (ks. Jerzy Chmiel). 1 (1985) 81-82

MIREVAL P., Lieux saints et pelerinages d'Orient (ks. Bogusław Nadolski TChr). 1 (1986) 80-81

MIREWICZ J., Na marginesie Biblii (ks. Henryk Weryński). 3 (1974) 195

Modlitewnik „Wielbij duszo moja Pana” (ks. W. P.). 3 (1949) 219-220

Mogilany 1993 (ks. Jacek Molka). 1 (1997) 75-77

MOJEK St., La centralità del sacrificio Eucaristico nella vita spirituale dei sacerdoti s econdo Pio XII (ks. Andrzej Fr. Dziuba). 1 (1983) 61-62

MONDIN B., Le teologie del nostro tempo (ks. Adam Kubiś). 5-6 (1976) 339-340

de MONLÉON J., Histoire sainte, commentaire historique et mistique (o. Paweł Sczaniecki OSB). 3-4 (1960) 372-374

MONLOUBOU L., Saint Paul et la prière (o. Tomasz M. Dąbek OSB). 2 (1984) 186188

MORGAN R., Biblical Interpretation (Michał Wojciechowski). 3 (1996) 211-213

MORINO C. G., Catechesi e catechisti (ks. Andrzej Fr. Dziuba). 4 (1989) 322-323

Mszał rzymski OO. Benedyktynów z 1963 r. (ks. Stanisław Piątek). 3 (1965) 191-192

Mszał z czytaniami w opracowaniu ks. T. Loski (ks. Stanisław Grzybek). 5 (1988) 453454

MÜLLER H. P., Vergleich und Methapher im Hohenlid (ks. Jerzy Woźniak CM). 4 (1987) 366-367

MÜLLER Th., Das Heilsgeschehen im Johannesevangelium (ks. Ludwik Stefaniak CM). 4 (1965) 250-251

MURPHY J., CONNOR O., La predication selon Saint Paul (ks. Edward Szymanek TChr). 4-5 (1967) 300-303

MURPHY R., A Study of Psalm 72/71 (ks. Zbigniew Kaznowski). 4-5 (1955) 284-285

Mysterium Salutis. Grundriis heilgeschichtlicher Dogmatic (ks. Adam Kubiś). 5-6 (1973) 343-344

MYŚLIWIEC K., Święte znaki Egiptu (ks. Jerzy Chmiel). 2 (1994) 135-136

NADOLSKI B., Liturgika (ks. Adam Durak SDB). 4-6 (1991) 158-159

NADOLSKI B., Ukochać Mszę świętą (ks. Andrzej Korpusik). 4 (1987) 368

NEHER A., Notes sur Qohelét (ks. Konrad Marklowski). 1 (1950) 210-214

Neues Bibel — Lexicon (ks. Jerzy Woźniak CM). 4 (1989) 318

Neues Testament und Kirche (ks. Feliks Gryglewicz). 4-5 (1974) 288-289 
Neutestamentliche Aufsätze Festschrift für prof. Josef Schmid (o. Andrzej Zon OSB). 1 (1964) 59-64

New Testament Abstracts (o. Stanisław Stańczyk CSsR). 3 (1957) 228-230

NIEWALDA P., Sakramentssymbolik im Johannes - evangelium? (ks. Stanisław Pisarek). 3 (1964) 189-196

NISIN A., Historia Jezusa (ks. Piotr Pajor). 4 (1967) 310-311

NITECKI P., Ks. Eugeniusz Dąbrowski (ks. Andrzej Fr. Dziuba). 2 (1983) 152-153

NORTH Chr. P., The Suffering Lervant in Deutero-Isaiah (ks. Witold Tyloch). 6 (1958) 558-561

NOWICKI P., Hebrajszczyzna biblijna (ks. Zdzisław Małecki). 6 (1978) 340-341

NOWICKI P., Język aramejski. Zagadnienia podstawowe (ks. Władysław Smereka). 4 (1961) 259-260

NOWICKI P., Pismo klinowe. Język akkadyjski (ks. Aleksy Klawek). 1 (1966) 59

Nowy Testament — 4 ewangelie w jednej (ks. Władysław Smereka). 3 (1948) 191

Nowy Testament w przekładzie ks. J. Wujka (ks. Stanisław Grzybek). 2 (1966) 144

Nowy Testament. Nowy przekład z języka greckiego na współczesny język polski (ks. Jerzy Chmiel). 1 (1992) 45-46

Obrzędy bierzmowania (o. Franciszek Małaczyński OSB). 1-2 (1975) 87-88

Obrzędy pogrzebowe dostosowane do zwyczaju diecezji polskich (ks. Stanisław Dadak). 2 (1978) 113-115

Od Nilu do Eufratu (Joachim Śliwa). 2 (1996) 132-133

OGRODZKI J., Słowo i kontemplacja (ks. Jerzy Chmiel). 3 (1998) 246

OLSZAŃSKI T., W światłach Męki Pańskiej (ks. Stanisław Grzybek). 3-6 (1990) 181182

OOSTERHUIS H., Quelqu' un parmi nous (ks. Bogusław Nadolski TChr). 1 (1970) 6364

Ordo Anni Sancti celebrandi in ecclesiis particularibus (o. Franciszek Małaczyński OSB). 4-5 (1974) 291-292

Ordo Lectionum pro Dominicis, Ferris et Festis Sanctorum (ks. Aleksy Klawek). 4-5 (1967) 303-305

ORDYK B., SATAŁA Z., Szalom Izrael (ks. Jerzy Chmiel). 2 (1994) 137

Oxford Bible series (Michał Wojciechowski). 4 (1995) 299-300

QUESSON N., 50 psaumes pour tous les jours (ks. Stefan Koperek CR). 1 (1983) 6364

„Pamiątka Pana” w Ziemi Świętej (ks. Jerzy Chmiel). 1 (1994) 66-67 
PANUŚ K., Kaznodziejstwo w katedrze krakowskiej (ks. Stanisław Obirek SJ). 1 (1996) 68-69

PANUŚ K., Uratować Naród (o. Wiesław Przyczyna CSsR). 4 (1996) 278

PARSCH P., Rok liturgiczny (o. Franciszek Małaczyński OSB). 1 (1959) 110-111

PARSCH P., Wtajemniczenie w ofiarę Mszy świętej (ks. Jan Wierusz- Kowalski OSB). 1 (1949) 68-69

Pascha nostrum (o. Paweł Sczaniecki OSB). 1 (1967) 58-60

PAUCHERI F., La Cresima sigillo della Spirito (o. Franciszek Małaczyński OSB). 3 (1975) 143

PAX El., Epiphaneia (ks. Lech Stachowiak). 3-4 (1960) 365-369

PENAR T., Semitic Philology and the Hebrew Fragments of Ben Sira (ks. Stanisław Łach). 5-6 (1976) 329

PESCH R., Der Prozess Jesu Geht weiter (ks. Jerzy Woźniak CM). 4 (1989) 318-319

Peshitta (ks. Jerzy Woźniak CM). 4 (1986) 366-367; 6 (1986) 530-531

Peshitta the Old Testament (ks. Jerzy Woźniak CM). 3 (1987) 264-265

Peshitta — The Old Testament in Syriac (ks. Jerzy Woźniak CM). 5-6 (1989) 403

PETER M., Wykład Pisma świętego Starego Testamentu (ks. Stanisław Grzybek). 3-4 (1960) 375-377

PETTINATO G., Ebla. Un impera inciso nell'argilla (ks. Stanisław Kur). 4 (1981) 250251

PETUCHOWSKI J., Wie unsere Meister die Schrift erklaren (ks. Bernard Wodecki SVD). 4 (1983) 282-283

Pieśń nad pieśniami (ks. Jerzy Chmiel). 3-4 (1993) 194-195

PIETRAS H., Dzień święty (ks. Jerzy Chmiel). 2 (1993) 111

Pismo święte Nowego Testamentu — przekład ks. S. Kowalskiego (ks. Wawrzyniec Gnutek). 2 (1959) 204-209

Pismo święte Starego i Nowego Testamentu (ks. Stanisław Grzybek). 2-3 (1963) 157159

PISAREK St., Cierpliwa wytrwałość (o. Augustyn Jankowski OSB). 3-4 (1993) 192193

PITSCH F., Durch Quiz zur Bibel (A. D.). 4 (1958) 357-358

PLÖGER I G., WEBER H. J., Der Diakon (ks. Jerzy Stefański). 4 (1984) 370-372

Podręczna konkordancja biblijna (ks. Stanisław Grzybek). 1 (1967) 64

POELMANN R., Le signe biblique des quarante jours (ks. Stanisław Grzybek). 6 (1965) 381-384

Polskie Qumranica (ks. Jerzy Chmiel). 1 (1992) 48-49 
Polskie śpiewy religijne społeczności kościelnych (ks. Jerzy Chmiel). 4-6 (1991) 162 Polszczyzna natchniona (ks. Jerzy Chmiel). 3 (1997) 234

PONIŻY B., Korzenie przesłania biblijnego Nowego Testamentu (ks. Stanisław Grzybek). 4 (1997) 309-311

PONIŻY B., Reinterpretacja wyjścia Izraelitów z Egiptu w ujęciu księgi Mądrości (o. Tomasz M. Dąbek OSB). 4-6 (1995) 156-157

POPLATEK Wł., Istota sumienia według Pisma św. (ks. Władysław Smereka). 1 (1962) 381-384

PORSCH F., Viele Stimmen - ein Glaube (Dominik Tomczyk SchP). 3 (1984) 279280

PRADO FLORES J., Mojżesz — Poza pustynię (ks. Jerzy Chmiel). 3 (1994) 221

Praktisches Bibellexikon (ks. Jerzy Chmiel). 1 (1978) 56

Présence de Saint Joseph au XVIIe siecle (ks. Michał Chorzępa CM). 4 (1989) 315-317

PRITCHARD J. E., Ancient Near-Easter Texts relating to the Old Testament (ks. Kazimierz Borowicz). 3 (1952) 275-276

Profesor i duszpasterz. Księga ku czci ks. W. Schenka (ks. Adam Durak SDB). 4-6 (1991) 160-161

Przewodnik po bibliografiach polskich judaików (ks. Jerzy Chmiel). 2 (1994) 136

PRZYBYSZEWSKI B., Romańskie kościoły pielgrzymkowe (ks. Jerzy Chmiel). 6 (1981) 396-398

Psałterz Dawidów (ks. Jerzy Chmiel). 3-4 (1993) 193-194

PYTEL J., Słowo Boże nie jest związane (o. Tomasz M. Dąbek OSB). 3 (1998) 244245

RABINOVICH A., Izrael (ks. Jerzy Chmiel). 3-6 (1990) 180

RACHWET G., Słownik cywilizacji egipskiej (ks. Jerzy Chmiel). 2 (1996) 135

von RAD G., Teologia Starego Testamentu (ks. Antoni Tronina). 2 (1987) 175-176

RAEDER S., Das Hebraeische bei Luther untersucht bis zum Ende der ersten Balmenvorlesung (ks. Aleksy Klawek). 1 (1965) 68

RAIMS J., Józef i jego bracia (ks. Jerzy Chmiel). 2-6 (1992) 109

RAK R., Od wszechświata stworzonego do człowieka odkupionego (ks. Jerzy Chmiel). 4 (1996) 282-283

RAMAZZOTTI B., Comunità e missione (ks. Andrzej Fr. Dziuba). 2 (1983) 151-152

RANOSZEK R., Mezopotamia i Syria (Tytus Górski). 6 (1949) 456

Reallexikon für Antike und Christentum (Tytus Górski). 5 (1962) 316-317

Recueil Lucian Cerfaux (Tytus Górski). 5 (1959) 528-531 
RECHOWICZ M., St. Jean Kanty a-t-il ete l'auteur du commentaire conciliariste sur l'Évangile de St. Matthieu? (ks. Eugeniusz Florkowski). 1 (1954) 180-184

RECHOWICZ M., SCHENK W., Studia z dziejów liturgii w Polsce (ks. Władysław Nowak). 1 (1976) 59-60

RECKENS H., Urgeschichte und Heilsgeschichte Israels Schau in die Vergangenheit nach Gen 1-3 (ks. Aleksy Klawek). 2 (1965) 116-118

REFOULE F., „Et ainsi tout Israel sera sauve” — Rom 11, 25-32 (o. Tomasz M. Dąbek OSB). 3 (1985) 258-259

Religia a literatura. Bibliografia (ks. Wiesław Wilk). 4 (1973) 239-240

Resurrexit Actes du Symposium (ks. Jerzy Chmiel). 4-5 (1975) 244

REVENTLOW H. G., Hauptprobleme des alttestamentlichen Theologie im 20 Jahrhundert (Dominik Tomczyk SchP). 2 (1985) 183-184

Revue de Qumran (o. Stanisław Stańczyk CSsR). 2 (1959) 211-213

RĘKAS M., Sakrament chorych (ks. Miłosław Kołodziejczyk). 1 (1962) 63-64

RICCIARDI A., Franciszka Siedliska (ks. Stanisław Grzybek). 2 (1989) 155-156

RICCIOTTI G., La Bibbia e le scoperte moderne (ks. Feliks Gryglewicz). 2 (1960) 182-183

RICHARD L., Le Mystere de la Redemption (ks. Kazimierz Romaniuk). 1 (1964) 5759

RICHTER K., Die katholische Kirche und das Judentum (ks. Leonard Górka SVD). 4 (1984) 369-370

RICHTER K., Hose unser Gebet (ks. Andrzej Korpusik). 4 (1989) 323-324

RIESNER R., Jesus als Lehrer (ks. Jan Łach). 3 (1984) 282-284

RITT H., Offenbarung der Johannes (ks. Andrzej Mozgol). 2 (1997) 164-166

Rivelazione e morale (ks. Feliks Gryglewicz). 5-6 (1973) 342-343

ROBERTSON E., The Old Testament Problem (ks. Kazimierz Borowicz). 4 (1952) 375-376

ROGER H., Jesus in His Own Words (ks. Władysław Smereka). 1 (1952) 94

ROGUET A. M., Table ouverte (ks. Bogusław Nadolski TChr). 4-5 (1971) 262-264

ROLLAND F., Les premièrs Évangiles (o. Tomasz M. Dąbek OSB). 6 (1985) 468-469

ROMANIUK K., „A wy za kogo mnie uważacie?” (ks. Jan Augustynowicz). 3 (1995) 222

ROMANIUK K., Czwarty rozdział Ewangelii Łukasza. (ks. Jerzy Chmiel). 3 (1996) 213-214

ROMANIUK K., Il timore di Dio nella teologia di San Paolo (o. Augustyn Jankowski OSB). 4-5 (1968) 316-317 
ROMANIUK K., Krótki zarys historii zbawienia (ks. Jerzy Chmiel). 6 (1975) 279-280

ROMANIUK K., L'amour du Père et du Fils dans la soteriologie de saint Paul (o. Augustyn Jankowski OSB). 2-3 (1963) 150-153

ROMANIUK K., Les chemins de l'exégese du Noveau Testament (ks. Stanisław Grzybek). 2 (1965) 127-128

ROMANIUK K., Le sacérdoce dans le Nouveau Testament (ks. Stanisław Grzybek). 3 (1967) 187-189

ROMANIUK K., Nie zaniedbuj w sobie charyzmatu (ks. Jan Augustynowicz). 4 (1995) 303-304

ROMANIUK K., Powołanie w Biblii. (ks. Jerzy Chmiel). 5-6 (1976) 341

ROMANIUK K., Wprowadzenie do krytyki tekstu Starego Testamentu (ks. Jerzy Chmiel). 6 (1975) 299

ROMANIUK K., Wprowadzenie metodologiczne do Nowego Testamentu (ks. Stan isław Grzybek). 2 (1967) 115-117

ROSŁON J. W., Podręcznik języka hebrajskiego (Andrzej Zaborski). 4-5 (1972) 296299

ROSŁON J. W., Zammeru maskil (ks. Jerzy Chmiel). 5 (1987) 455-456

ROSŁON J. W., ŁACH S., Studia z biblistyki (ks. Stanisław Grzybek). 4 (1978) 226227

ROSSANO P., RAVASI G., GIRLANDA A., Nuovo Dizionario di Teologica Biblica (ks. Jerzy Chmiel). 3-6 (1990) 170

ROUET A., La Messe dans l'histoire (ks. Bogusław Nadolski TChr). 6 (1980) 261-262

ROUX J. P., Jesus (ks. Jerzy Chmiel). 1 (1994) 65-66

ROWLEY H. H., Studies in Old Testament Prophecy (ks. Władysław Borowski CRL). 1 (1955) 62-65

ROWLEY H. H., The Old Testament and modern Study (ks. Czesław Jakubiec). 5-6 (1952) 492-496

ROWLEY H. H., The Zadokite Fragments and the Dead Sea Scrolls (ks. Henryk Strakowski). 6 (1957) 474-475

RÓŻYCKI I., Podstawy sakramentologii (ks. Adam Kubiś). 4-5 (1971) 261-262

RUBINKIEWICZ R., Eschatologia Hen 9-11 a Nowy Testament (ks. Jan Szlaga). 2 (1985) 182-183

RUBINKIEWICZ R., Wprowadzenie do apokryfów Starego Testamentu (ks. Stanisław Mędala CM). 6 (1987) 544-546

RUCKSTUHL E., Die Chronologie des letzten Mahles und des Leidens Jesu (ks. Jan Łach). 1 (1966) 60-63

RUDOWICZ E., Ziemia Święta (ks. Stanisław Grzybek). 3-4 (1960) 381-383 
RUMAK J., Mistyka świętego Pawła Apostoła (ks. Andrzej Fr. Dziuba). 6 (1981) 394395

RUSECKI M., Wierzcie swoim dziełom (Eugeniusz Sakowicz). 4 (1989) 320-321

Sakrament chrztu (ks. Stanisław Rumiński). 4-5 (1974) 290

Sakramenty święte (ks. Eugeniusz Florkowski). 4-6 (1956) 308-310

SALVADOR MUÑOZ I., Et Evangelio de Maria (ks. Jan Łach). 5 (1980) 298-299

SANDAUER A., „Bóg. Szatan. Mesjasz.” (ks. Jerzy Chmiel). 5 (1977) 289-290

SAOÛT Y., Le grand souffle de l'Exode (ks. Jerzy Chmiel). 4 (1978) 225-226

SARTORY Th., Die Ökumenische Bewegung und die Einheit der Kirche (ks. Stefan

Mojsa SJ). 5 (1960) 494-496

Satelitarny atlas Ziemi Świętej (Joachim Śliwa). 2 (1996) 130-132

SCIAMÉ U. G., La musica sacra nella liturgia oggi (ks. Andrzej Fr. Dziuba). 5 (1984) $451-452$

SCHARBERT J., Der Schmerz in Alten Testament (ks. Kazimierz Barcki). 4 (1957) 341-345

SCHARBERT J., Einführung in die Heilige Schrift (ks. Antoni Dreja). 1 (1964) 54-55

SCHARBERT J., Heilsmittler im Alten Testament und im Alten Orient (ks. Aleksy Klawek). 1 (1965) 54-56

SCHARBERT J., Numeri (ks. Jan Łach). 3-4 (1993) 190 -191

SCHEFFCZYK L., Das biblische Zeugnis von Maria (ks. Andrzej Fr. Dziuba). 2 (1981) 136-137

SCHELKLE K. H., Die Kraft des Wortes (Dominik Tomczyk SchP). 1 (1985) 74-75

SCHENK W., Liturgia sakramentów świętych (ks. Romuald Rak). 4 (1965) 246-248

SCHENRING L., Due per la gioios il cammino esaltante di una coppia di sponsi (ks. Andrzej Fr. Dziuba). 1 (1985) 82-83

SCHICK E., Alten Altes werden (Dominik Tomczyk SchP). 6 (1985) 472

SCHILDENBERGER J., Literarische Arten der Geschichtsschreibung in Alten Testament (ks. Aleksy Klawek). 6 (1965) 384

SCHILLING O., Das Mysterium Lunae (ks. Aleksy Klawek). 1 (1965) 64

SCHLIER H., Grundzuge einer paulininische Theologie (Dominik Tomczyk SchP). 5 (1984) 449-450

SCHMID J., Studien zur Geschichte des griechischen Apokalypse - Texte (ks. Ludwik Stefaniak CM). 4 (1957) 345-348

SCHMIDT N., Sinai und Rotes Meer (Joachim Śliwa). 2 (1995) 154-156

SCHNACKENBURG R., La Théologie du Nouveau Testament - Neutestamentliche Theologie (ks. Ludwik Stefaniak CM). 2 (1964) 125-127 
SCHNACKENBURG R., ERNST J., WANKE J., Die Kirche des Anfangs (ks. Michał Czajkowski). 6 (1980) 360-361

SCHNEIDER G., Die Apostelgeschichte (ks. Stanisław Haręzga). 2 (1981) 139-140

SCHNIDER F., Die verlorenen Söhne (Janusz Tum). 6 (1981) 395-396

SCHNITKER T., SLABY W., Concordantia verbalia Missali Romani (ks. Bogusław Nadolski TChr). 5 (1984) 450

SCHNITZLER T., Die Messe der Betrachtung (ks. Stanisław Piątek). 2 (1970) 160

SCHREINER J., „Die eine Gott Israels” (ks. Zdzisław Małecki). 1 (1998) 76-77

SCHREINER J., Theologie des Alten Testaments (ks. Zdzisław Małecki). 4 (1995) 300-301

SCHREINER J., Wort und Botschaft des Alten Testament (ks. Stanisław Grzybek). 5-6 (1973) 333-335

SCHULZ H. J., Die byzantinische Liturgie (ks. Leonard Górka SVD). 5 (19 81) 313314

SCHÜRMANN H., Die egzegetische Seminararbeit (ks. Stanisław Grzybek). 1 (1969) 54-55

SCHÜRMANN H., Die geistlichen Gnadengaben in den paullinischen Gemeinden (ks. Jan Szlaga). 6 (1967) 383-384

SCHÜRMANN H, Gottes Reich - Jesu Geschich (ks. Dominik Tomczyk SchP). 3 (1988) 268-269

SCHÜRMANN H, Studien zur neutestamentlichen Ethik (ks. Jerzy Chmiel). 1-3 (1991) 79-80

SCHÜRMANN H., Worte des Herrn Jesu Botschaft vom Königtum Gottes auf Grund der synoptischen Uberlieferung zusammengestellt (o. Augustyn Jankowski OSB). 3 (1966) 207

SCZANIECKI P. OSB, Msza po staremu się odprawia (ks. Jan Kowalski). 4-5 (1967) 319-320

SEGERT S., Altaramäische Grammatik (ks. Jerzy Chmiel). 5 (1977) 281

SEYNAEVE J., Cardinal Newman's Doctrine of Holy Scripture (ks. Eugeniusz Florkowski). 4-5 (1955) 278-280

SIEDLECKI J., Śpiewnik kościelny (Redakcja). 1 (1953) 221-222; (o. Franciszek Małaczyński OSB). 5 (1961) 270-271

SINKA T., Literatura grecka (ks. Piotr Stach). 2 (1952) 179-187

SINKA T., Zarys liturgiki (ks. Władysław Bomba CM). 1 (1989) 75-76

SIUDY T., Refleksje maryjne (ks. Stanisław Grzybek). 4 (1994) 288-290

SIWEK G., Homilie obrzędowe (ks. Andrzej Kołek). 2 (1998) 152-153

Skarbnica modlitw (ks. Jerzy Chmiel). 2 (1998) 153-154 
SKRINJAR A., Teologija sv. Ivana (ks. Feliks Gryglewicz). 2-3 (1976) 175-176

SKOWRONEK A., Sakrament in der evangelischen Theologie der Gegenwart (ks. Stanisław Rumiński). 3 (1974) 195-196

SŁOMKOWSKI A., Problem pochodzenia człowieka (ks. Antoni Cząstka). 4 (1958) 363-366

Słownik do nowego Psałterza (Redakcja). 4-6 (1956) 327-328

Słownik teologów polskich (ks. Jan Kracik). 4 (1983) 373-376

SMOLEŃ W., Ilustracja świąt kościelnych w polskiej sztuce (ks. Jan Kuś). 5 (1988) 453-454

Sobór drogowskazem (ks. Stanisław Grzybek). 4 (1989) 319-320

SODI M., MORANTE G., Anno liturgico: itinerario di fede e di vita (ks. Jerzy Stefański). 4-6 (1991) 159

SOLAK E., Nowobułgarska Biblia i jej język (ks. Jerzy Chmiel). 1 (1998) 77

SONNEN J., Die Beduinen am Sec Genesareth (ks. Sylwester Baksik). 1 (1954) 57-58

Specimen Examinis Ordinandorum (ks. Tadeusz Szwagrzyk). 3 (1957) 230-231

SPEISER E. A., Genesis. Introduction, translation and Notes (ks. Stanisław Mędala CM). 4-5 (1968) 322-324

SPICQ C. S., Agapè dans la Nouveau Testament (ks. Stanisław Grzybek). 3-4 (1960) 377-379

SPICQ C. S., Spiritualité Sacerdotale d' après Saint Paul (ks. Jan Drozd SDS). 1 (1953) 214-219

SQUARNEC M., Vivere, credere, celebrare (ks. Jerzy Stefański). 1 (1986) 81-82

STACHOWIAK L., Chrestotes (ks. Jan Stępień). 6 (1958) 569-572

STACHOWIAK L., Księga Jeremiasza (o. Hugolin Langkammer OFM). 2-3 (1969) 174-177

STACHOWIAK L., Potop biblijny (ks. Jan Augustynowicz). 3-6 (1990) 172

STACHOWIAK L., Prorocy — słudzy Słowa (ks. Stanisław Grzybek). 2 (1981) 137139

STANTON G. N., The Gospels and Jesus (Michał Wojciechowski). 3 (1996) 209-211

STARCZEWSKA A. I., Listy do Ciebie (ks. Tadeusz Olszański CM). 2 (1993) 111-112

Starożytne dzieje i kultura (Joachim Śliwa). 2 (1996) 134-135

STEFAŃSKI J., Sakrament chorych w reformie Soboru Watykańskiego II (ks. Czesław Krakowiak). 5 (1988) 451-453

STEINMANN J., Le prophéte Isaie (ks. Stanisław Grzybek). 5-6 (1952) 496-499

STEINMUELLER J. E., SULLIVAN K., Catholic Biblical Old and New Testament Encyclopedia (ks. Ludwik Stefaniak CM). 4-6 (1956) 318-320 
STENDEBACH F. J., Der Mensch wie ihn Israel vor 3000 Jahren sah (ks. Stanisław Grzybek). 5-6 (1973) 331-333

STĘPIEŃ J., Teologia swiętego Pawła - Człowiek i Kościół w zbawczym planie Boga (ks. Stanisław Grzybek). 6 (1980) 262-264

STOFF M., Ägyptische Siegelac mulette in menschlicher und trierischer Gestalt (Joachim Śliwa). 2 (1996) 133-134

STRĄKOWSKI H., Chrystus - Baranek w Piśmie świętym (ks. Ryszard Karpiński). 1 (1963) 61-62

STRĄKOWSKI H., Manuskrypty z Qumran a chrzescijaństwo (ks. Ludwik Stefaniak CM). 4 (1958) 359-360

Studia Gnesnensis, t. I. (ks. Bernard Wodecki SVD). 4 (1976) 238-240

Studia Jasnogórskie, t. V. (ks. Jan Kuś). 1 (1985) 84-85

Studia liturgiczne, t. V (Jerzy Flaga). 2 (1989) 153-154

Studia Płockie (ks. Wojciech Góralski). 4-5 (1974) 292

Studia z archeologii Azji Przedniej i Starożytnego Wschodu (Tadeusz Bartkowiak). 4-5 (1971) 259-261

Studies in Ancient Art and Civilization (ks. Jerzy Chmiel). 2 (1997) 168

STUMMER F., Geographie des Buches Judith (ks. Stanisław Grzybek). 6 (1949) 455456

STYŚ S., Biblijne ujęcie stworzenia świata wobec nauki (ks. Stanisław Papier). 2 (1948) 119-120

de SURGY P., GRELOT P., CARRES M., GEORGE A., DELORME J., LÉON- DUFOUR X., La Résurrection du Christ et l'éxégese moderne (ks. Edward Szymanek TChr). 2-3 (1969) 179-184

SWANSON R. J., The Horizontal Line Synopsis of the Gospel (ks. Jan Szlaga). 5-6 (1976) 339

Synoptische Studien (ks. Tadeusz Szczurek). 2 (1957) 164-167

SZCZEPKINA M. W., Miniatury Chłudowskoj Baltyri (ks. Jerzy Chmiel). 6 (1978) 343

SZLAGA J. (red.), U boku Syna (Dominik Tomczyk SchP). 6 (1985) 470

SZOSTKIEWICZ Z., WESOŁY S., Bibliographia Mariana Polonorum ab anno 1903 ad anno 1955 (ks. Eugeniusz Florkowski). 4-6 (1956) 306-308

SZULC Fr., Struktura teologii judeochrzescijańskiej w świetle badań Jeana Danielou (ks. Jerzy Chmiel). 6 (1983) 556

SZYFMAN J. Ch., Finikijski język (ks. Aleksy Klawek). 2 (1965) 112

ŚLIWA J., Skarabeusze egipskie (ks. Jerzy Chmiel). 2 (1996) 135-136

ŚWIDERKÓWNA A., Prorocy (ks. Jan Augusrtynowicz). 4 (1995) 303 
ŚWIECZYŃSKI J., Wskrzesiciele faraonów i pogromcy sztuki (Marian Fular). 2-6 (1992) 110

ŚWIERZAWSKI W., Liturgia uświecenia czasu (ks. Jan Decyk). 4-5 (1985) 368

Teologia moralna w obliczu aktualnego stanu etosu polskiego (ks. Andrzej Franciszek Dziuba). 2-3 (1979) 173-174

The Anchor Bible Dictionary (ks. Andrzej Mozgol). 2 (1997) 162-164

The Bulletin of the University Museum of the University of Pennsylvania (Zdzisław Kapera). 2 (1965) 120-123

The New Jerome Biblical Commentary (ks. Jerzy Chmiel). 3-6 (1990) 171

The Old Testament in Syriac according to the Peshitta Version (ks. Jerzy Woźniak CM). 2 (1986) 173-174

Théologie et pratique de la Concélèbration (ks. Stanisław Burzawa). 1-2 (1968) 122123

Theologischer Handkommentar zum Neuen Testament (ks. Jan Drozd SDS). 2-3 (1969) 159-167

Dom THIERRY MAERTENS, Au Couer de Notre Pastorale: La Semaine Sainte (o. Franciszek Małaczyński OSB). 2 (1958) 175-176

Dom THIERRY MAERTENS, Le sept jours Genèse I (ks. Kazimierz Borowicz). 5-6 (1952) 499-500

THILS G., Histoire doctrinale du mouvement écumenique (ks. Stefan Moysa SJ). 5 (1960) 491-494

THURIAN M., O Eucharystii i modlitwie (ks. Andrzej Korpusik). 5 (1998) 449-451

THÜSING W., Herrlichkeit und Einheit (ks. Wojciech Zalewski). 2 (1964) 127-129

TILBURY N., Izrael (ks. Jerzy Chmiel). 4 (1994) 290

TOAFF E., Perfidi Giudei fratelli maggiori (ks. Jerzy Chmiel). 2 (1994) 136-137

TRESMONTANT C., Le Prophétisme hébreu (ks. Tadeusz Brzegowy). 4 (1984) 365367

TREU K., Die griechischen Handschriften des Neuen Testaments in UdSSR (ks. Aleksy Klawek). 2 (1967) 120-121

TRILLING W., Denn Staub bist du Eine Einführung in den Bericht vom Paradies und Sundetall (ks. Aleksy Klawek). 4-5 (1966) 317-318

TRILLING W., Im Aufang schuf Gott (ks. Aleksy Klawek). 2 (1965) 115-116

TRILLING W., Untersuchungen zum zweiten Thessalicherbrief (ks. Feliks Gryglewicz). 5-6 (1973) 341

TRONINA A., „Panie, abym przejrzał” (ks. Julian Warzecha SAC). 2 (1998) 149-151

TRUBLET J., ALETTI J. N., Aproche poétique et théologique des Psaumes (ks. Julian Warzecha SAC). 6 (1985) 463-464 
TUDDA F., La Bibbia libro di autentica esperienza religiosa (ks. Andrzej Dziuba). 4 (1981) 252-253

TURBAK F., „Pójdź za Mną” (o. Franciszek Małaczyński OSB). 6 (1958) 572-576

URBAŃCZYK St., Z dawnych stosunków językowych polsko-czeskich. cz. I: Biblia królowej Zofii a staroczeskie przekłady Pisma św. (ks. Władysław Smereka). 2 (1951) 236-240

UFNIARSKI St., Międzynarodowe Stowarzyszenie Badaczy Pisma świętego (ks. Władysław Smereka). 5-6 (1948) 356-358

U źródeł mądrosci (ks. Jerzy Chmiel). 3 (1997) 228

YERKES R. K., La sacrifice dans les religions grecque et romaine et dans judaisme primitif (Tytus Górski). 2 (1960) 185-190

YIGAEL I., The Ben Sira Scrolls of Masada (ks. Aleksy Klawek). 4-5 (1966) 320

VAGANY L., La Probleme Synoptique (ks. Stanisław Grzybek). 1 (1958) 72-76

VAGANY L., AMPHOUX C. B., Initiation à la critique textuelle du Nouveau Testament (ks. Jerzy Chmiel). 3-6 (1990) 175-176

VANDERKAM J. C., Manuskrypty znad Morza Martwego (Piotr Muchowski). 3 (1998) 240

de VAUX R., La Genèse (ks. Kazimierz Borowicz). 4 (1952) 373-375

de VAUX R., Les sacrifices de l'Ancien Testament (ks. Kazimierz Borowicz). 2 (1964) 116-118

de VAUX R., STEVE A. M., Fouilles à Qaryet el — 'Enab (Tytus Górski). 4 (1952) 370-371

VERMES G., Les manuscrits du désert de Juda (ks. Henryk Strąkowski). 6 (1957) 478482

VOGEL C., Introduction aux sources de l'histoire du culte chrétien au Moyen Âge (ks. Stanisław Burzawa). 1-2 (1968) 120-122

VOGEL C., Le pécheur et la pénitence dans l'Eglise ancienne (ks. Stanisław Burzawa). 4-5 (1967) 313-314

VÖLKL R., Dinende Kirche - Kirche der Liebe (ks. Franciszek Woronowski). 6 (1972) 368-369

WATSON W. G., Classical Hebrew Poetry (Maria Kantor). 3-6 (1990) 175

WATSON D. F., HAUSER A. J., Rhetorical Criticism of the Bible (ks. Wiesław Alicki). 1 (1998) 75-76

WERYŃSKI H., W apostolskiej szkole (ks. Ludwik Stefaniak CM). 1 (1963) 63-64

WIENER C., Récherches sur l'amour pour Dieu dans l'Ancien Testament (ks. Stanisław Grzybek). 5 (1959) 531-532

WILSON J., The Turin Shroud (ks. Zbigniew Kaznowski). 3 (1981) 186-187 
WHITELEY D. E., The Theology of St. Paul (ks. Ludwik Stefaniak CM). 4 (1965) 251-253

WITCZYK H., Teofania w Psalmach (ks. Antoni Tronina). 6 (1986) 531-532

WITEK St., Sakrament Pojednania (ks. Jan Kowalski). 3 (1980) 178-179

W kręgu Dobrej Nowiny (ks. Jerzy Chmiel). 5 (1987) 452-453

WŁODARCZYK St., Realizacja zbawienia „dzis’” w Chrystusie (ks. Jerzy Chmiel). 1 (1992) 46

WOJTYŁA K., U podstaw odnowy (ks. Adam Kubiś). 4-5 (1972) 299-300

WOLNIEWICZ M., Studium Pisma świętego w Arcybiskupim Seminarium Duchownym w Poznaniu w latach 1835-1939 (ks. Edward Szymanek TChr). 4-5 (1971) 257-259

WOLSKI J., Historia powszechna. Starożytność (ks. Aleksy Klawek). 4-5 (1966) 316317

WÓJCIK St., Księga Psalmów oraz pieśni biblijne (ks. Stanisław Grzybek). 1 (1960) $77-80$

WÓJCIK St., Wielki Tydzień według porządku wznowionego (ks. Tadeusz Szwagrzyk). 3 (1957) 231-233

Wprowadzenie do liturgii (ks. Jan Kowalski). 1-2 (1968) 118-120

Wstęp do Nowego Testamentu (ks. Jan Kanty Pytel). 4-5 (1970) 243-246

Wstęp do Starego Testamentu (o. Hugolin Langkammer OFM). 4-5 (1974) 285-287

Wstęp ogólny do Pisma świętego (ks. Jerzy Chmiel). 4-5 (1974) 287-288

Wypisy źródłowe do dziejów Wawelu (ks. Jerzy Chmiel). 1 (1985) 84

ZAWADZKI R. M., Spuścizna pisarska Stanisława ze Skalbimierza (ks. Jerzy Chmiel). 6 (1981) 398-399

ZDUNKIEWICZ-JEDYNAK D., Językowe środki perswazji w kazaniu (Renata Przybylska). 4 (1996) 279-282

ZDZIARSTEK R. S., Chrystologia świętego Pawła. Aspekt ontyczny (ks. Janusz Królikowski). 3-6 (1990) 177-178

ZEDDA S., La prima lettura di san Paolo (ks. Kazmierz Romaniuk). 5 (1964) 328-329

ZERFASS R., Od aforyzmu do kazania (Piotr Urbański). 2 (1996) 137-140

ZERWICK U., De matrimonio et divortio in Evagelio (Tytus Górski). 1-2 (1961) 77-80

ZIEJA J., Przyjdź Panie. Ewangelia i życie (ks. Stanisław Grzybek). 3 (1966) 208

ZIMMERMANN A., Radujcie się! Kazania niedzielne i świąteczne (ks. Stanisław Rumiński). 2-3 (1979) 174-175

ZIMMERLI W., Grundriss der alttestamentlichen Theologie (ks. Stanisław Grzybek). 5-6 (1976) 330-331; 5-6 (1973) 336-337 
ZIMOŃ D., Czas zbawienia (ks. Roman Kempny). 2 (1993) 110-111

ZIÓŁKOWSKI Z., Spotkanie z Biblią (ks. Stanisław Mędala CM). 2-3 (1970) 156-159

ZUBERBIER A., Gdy zajął z Nim miejsce u Stołu (ks. Janusz Królikowski). 2 (1993) 108-109

Zwycięzca śmierci (Marian Fular). 2 (1987) 181

Życie Jezusa według czterech ewangelistów (ks. Jerzy Chmiel). 4 (1984) 367-368

Żydzi w dawnej Rzeczypospolitej (ks. Jerzy Chmiel). 2-6 (1992) 109

ŻMIJEWSKI J., Das Neue Testament (ks. Dominik Tomczyk SchP). 4 (1987) 367-368

\section{DOKUMENTY}

EPISKOPAT POLSKI, Instrukcja o muzyce liturgicznej po Soborze Watykańskim II. 3 (1981) 141-148

- Instrukcja o wprowadzeniu w życie przywileju Stolicy Apostolskiej z dnia 7 lipca 1961 r. 6 (1961) 331-333

- List do duchowieństwa w związku z wejściem w życie konstytucji soborowej „O liturgii świętej”. 3 (1964) 134 - 138

— List pasterski biskupów polskich z okazji wejścia w życie soborowej konstytucji „O liturgii świętej”. 3 (1964) 129-134

— List pasterski o nowym rytuale. 4 (1963) 220-222

- Objaśnienia do konstytucji „O zachowaniu dyscypliny postu eucharystycznego". 1-6 (1953) 193-198

- Przekład Ordo Missae ustalony przez Komisję Liturgiczną Episkopatu Polski do modlitewników i publicznego używania w kościele. 5 (1958) 369-383

- Regulamin Komisji Episkopatu Polski do Spraw Liturgii i Duszpasterstwa Liturgicznego. 1 (1981) 1-5

— Śpiewnik mszalny, cz. 1.1 (1970) 45-60

- Zalecenia duszpasterskie w związku z Dyrektorium o Mszach św. z udziałem dzieci. 2-3 (1977) 86-89

Formularz mszalny na Rok Święty (przekł. o. Franciszek Małaczyński OSB). 4-5 (1974) 275-279

Innowacje we Mszy św. 4 (1965) 241-245

Instrukcja o tłumaczeniu tekstów liturgicznych (przekł. ks. Jan Adamecki). 6 (1971) 320-329

JAN XXXIII, Pismo apostolskie zatwierdzające zbiór nowych rubryk brewiarza i mszału rzymskiego (przekł. o. Franciszek Małaczyński OSB). 6 (1960) 499-502 
JAN PAWEŁ II, List apostolski „Redemptionis anno”. 4 (1984) 285-289

Kalendarz powszechny ad iterum. 1 (1970) 23-32

Kalendarz powszechny rzymski. 1 (1970) 33-42

Komunikat końcowy IV sesji plenarnej Katolickiej Federacji Biblijnej — Bogota 1990 (przekł. ks. Bernard Wodecki SVD i Maria Kantor). 1 (1992) 24-38

Konstytucja dogmatyczna „O Objawieniu Bożym” (wersja łacińska i polska). 1 (1966) $2-25$

Konstytucja „O liturgii świętej”. 3 (1964) 147-174

KONGREGACJA KULTU BOŻEGO, Deklaracja w sprawie Modlitw eucharystycznych i eksperymentów w liturgii (przekł. o. Franciszek Małaczyński OSB). 5 (1988) 391-394

- Dekret - Obrzędy bierzmowania (przekł. o. Franciszek Małaczyński OSB). 1-2 (1975) 7-18

- Dekret - Obrzędy sakramentu pokuty (przekł. o. Franciszek Małaczyński OSB). 6 (1974) 293-311

- Dekret o zmianie daty liturgicznego obchodu św. Jadwigi królowej. 1 (1998) 74

- Dyrektorium o Mszach św. z udziałem dzieci. 2-3 (1977) 71-85

- Komunikat o zwyczaju noszenia krzyża przez biskupów. 2 (1998) 147

- List okólny o przygotowaniu i obchodzeniu świąt Wielkanocnych (przekł. o. Franciszek Małaczyński OSB). 5 (1988) 369-391

- Wprowadzenie do nowych obrzędów pogrzebowych (przekł. o. Franciszek Małaczyński OSB). 1-2 (1974) 1-5

KONGREGACJA OBRZĘDÓW, Decretum de nova formula in sacrae communionis distributione. 4 (1964) 249-250

- Decretum de nova pia invocatione in laudem Spiritus Sancto Paracliti. 4 (1964) 250

- Dekret generalny o uproszczeniu rubryk (przekł. ks. Tadeusz Szwagrzyk). 2-3 (1955) 149-155

- Dekret ogólny ogłaszający nowy kodeks rubryk brewiarza i mszału rzymskiego (przekł. o. Franciszek Małaczyński OSB). 6 (1960) 503

- Dekret ogólny ogłaszający obrzędy koncelebry oraz komunii pod obiema postaciami (przekł. o. Franciszek Małaczyński OSB). 3 (1966) 145-147

- Dekret ogólny o odnowieniu porządku nabożeństw podczas Wielkiego Tygodnia. 3-4 (1955) 230-233

- Dekret o odmawianiu modlitw po mszy czytanej. 5 (1960) 487

— Dekret o reformie obrzędu chrztu. 6 (1971) 273-288 
— Dekret o święcie Najświętszego Serca Jezusowego w 1962 r. 3 (1962) 183

- Dekret o ustanowieniu patronów Polski (dioecesium Poloniae). 5 (1962) 314

- Dekret wprowadzający nowe modlitwy eucharystyczne i prefacje. 6 (1968) 325-344

- De usu grammophonii et de horis mixtis in Ecclesiis. 4 (1957) 314-316

- Druga instrukcja o należytym wykonywaniu konstytucji „O świętej liturgii". 2 (1967) 65-71

- Dubia circa interpretationem instructionis de musica sacra. 3 (1962) 185.

- Historia wypominków czyli wspólnej modlitwy wiernych (przekł. o. Paweł Sczaniecki OSB). 4 (1965) 221-226

- Instructio pro sacerdote infirmo vel caecutiente circa missarum votivarum celebrationem eidem Apostolico indulto concessam. 3 (1962) 180 - 181

- Instrukcja o muzyce sakralnej i liturgii według wskazań encykliki papieża Piusa XII „Musicae sacrae disciplina” oraz „Mediator Dei” (przekł. benedyktynów tynieckich). 1 (1959) 66-77

- Instrukcja do należytego wprowadzenia w życie konstytucji „O świętej liturgii”(przekł. ks. Stanisław Grzybek). 1 (1965) 21-43

- Instrukcja o należytym odprawianiu odnowionego porządku Wielkiego Tygodnia. 3-4 (1955) 233-239

— Język polski we Mszy świętej. 6 (1961) 330 - 331

- Objaśnienia czynności liturgicznych podczas Świętego Triduum zgodnie $\mathrm{z}$ odnowionym porządkiem Wielkiego Tygodnia (przekł. ks. Brunon Magott). 6 (1955) 354-355

- Obrzędy mszy koncelebrowanej (przekł. R[yszard] W[ilczyński]). 3 (1966) 147-166

— Odpowiedź dana diecezji paryskiej. 1 (1957) 59-60

- Odpowiedź na wątpliwości w związku z dekretem C. R. C. z dnia 23 marca 1955 (przekł. ks. Brunon Magott). 6 (1955) 355-360

- Odpowiedź na wątpliwości w związku z thumaczeniem dekretu C. R. C. z dnia 23 marca 1955 „O uproszczeniu rubryk” (przekł. ks. Brunon Magott). 5 (1955) 360-362

- Ordo Missae - Obrzędy Mszy św. (przekł. ks. Ryszard Wilczyński). 1 (1970) 4-22

- Pismo okólne do przewodniczącego Konferencji Biskupów w sprawie troski o historyczno-artystyczne dziedzictwo Kościoła. (przekł. o. Franciszek Małaczyński OSB). 1 (1972) 33-35 
- Rubryki mszału i brewiarza rzymskiego (przekł. o. Franciszek Małaczyński OSB). 6 (1960) 504-636

- Wspólna modlitwa wiernych (przekł. o. Paweł Sczaniecki OSB). 4 (1965) 211-221

- Wyjaśnienie dotyczące czynności liturgicznych w czasie „Świętego Triduum" zgodnie z odnowionym porządkiem Wielkiego Tygodnia (przekł. ks. Tadeusz Szwagrzyk). 1 (1957) 53-54

- Wyjaśnienie o typicznym wydaniu drugiej części pontyfikału rzymskiego. 3 (1962) 184

- Wyjaśnienie o zmianach w kalendarzach partykularnych (przekł. o. Franciszek Małaczyński OSB). 6 (1960) 637-638

- Wyjaśnienie wątpliwości, które powstały przy interpretacji kodeksu rubryk. 3 (1962) 183-184

- Wyjaśnienie w sprawie formularza Mszy św. w oktawie Bożego Narodzenia oraz mszy wieczornych. 3 (1962) 185-186

— Wyjaśnienia w sprawie Wielkiego Tygodnia. 1 (1957) 57-58

- Zmiany tekstu modlitwy o nawrócenie Żydów w Wielki Piątek. 6 (1959) 600

- Zmiany w kodeksie rubryk. 6 (1961) 330

- Zarządzenia i wyjaśnienia do odnowionego porządku nabożeństw podczas Wielkiego Tygodnia (przekł. ks. Tadeusz Szwagrzyk). 4-6 (1956) 302-306

KONGREGACJA SAKRAMENTÓW, Dekret Kongregacji o wspomnieniu obowiązkowym błog. Jadwigi królowej w diecezjach polskich. 1 (1980) 43

- Dekret w sprawie aktów uwielbienia. 5 (1961) 232

- Tekst Mszy i Liturgii Godzin na wspomnienie obowiązkowe błogosławionej Jadwigi królowej. 1 (1980) 39-43

KONGREGACJA SPRAW KANONIZACYJNYCH, Deklaracja o błogosławionej Jadwidze królowej Polski (przekł. Roman Zawadzki). 1 (1987) 64-65

KONGREGACJA ŚWIĘTEGO OFFICIUM, Decretum de ieiunio eucharistico a sacerdotibus litantibus servandam. 4 (1964) 249

- Instructio „De disciplina circa ieiunium eucharisticum servanda”. 1-6 (1953) 189-193

- Instrukcja w sprawie konstytucji apostolskiej „Christus Dominus”. 1 (1953) 189-193

- Reforma rubryk w mszale. 1-6 (1954) 205-210

KONGREGACJA WYCHOWANIA KATOLICKIEGO, Instrukcja o liturgicznej formacji w seminariach. 5 (1987) 369-389 
- Wykaz zagadnień, które winny być uwzględnione w liturgicznej formacji alumnów. 5 (1987) 390 - 404

Ogólne wprowadzenie do mszału rzymskiego (przekł. Komisji Episkopatu do Spraw Liturgii). 1 (1971) 1-79

PAPIESKA KOMISJA BIBLIJNA, Biblia a chrystologia (przekł. o. Augustyn Janko wski OSB). 3 (1988) 185-226

- Instrukcja dotycząca stowarzyszeń, kongresów i zjazdów biblijnych (przekł. ks. Ludwik Stefaniak CM). 1-3 (1956) 139-142

- O pierwszych rozdziałach księgi Genesis (przekł. o. Efrem Gliński OP). 3 (1948) 126-129

— Tekst autentyczny listu Komisji Biblijnej. 4 (1948) 200-201

PAWEŁ VI, Do biblistów włoskich (wrzesień 1968). 6 (1968) 280-282

- Dekret o apostolstwie świeckich. 6 (1966) 321-345

- Konstytucja apostolska „Indulgentiarum doctrina” z dnia 1.01 .1967 r. 1 (1967) 1-13

- Konstytucja apostolska o sakramencie bierzmowania (przekł. o. Franciszek Małaczyński OSB). 1-2 (1975) 1-6

- List apostolski „Motu proprio Sedula cura” o reorganizacji Papieskiej Komisji Biblijnej (przekł. ks. Jerzy Chmiel). 1 (1972) 30-32

- List apostolski „Sabaudiae Gemma” (Czterechsetna rocznica urodzin św. Franciszka Salezego). 4-5 (1967) 279-288

- Teologia a Magisterium Kościoła (przekł. ks. Aleksy Klawek). 4-5 (1966) 209-215

PIUS XII, Constitutio apostolica „De disciplina servanda quoad ieiunium eucharisticum”. 1 (1953) 175-184; przekład polski: 180-189

- Encyklika „Divino afflante Spiritu” (O właściwy rozwój studiów biblijnych) z dnia 30 września 1943 r. (przekł. Zygmunt Wawszczak). 3 (1958) 248-268

- Encyklika „In multiplicibus” (W sprawie przywrócenia pokoju w Palestynie). 1 (1949) 6-9

- Encyklika „Musicae sacrae disciplina” - O muzyce sakralnej (przekł. ks. Karol Mrowiec CM). 6 (1955) 335-353

- Encyklika „Redemptoris nostri” (O miejscach świętych w Palestynie). 3 (1949) 155-157

- Encyklika z dnia 15 maja 1956 r. dotycząca kultu Najświętszego Serca Jezusowego (przekł. ks. Michał Rękas). 2 (1957) 135-163

- Motu proprio - Indulty uzupełniające konstytucję apostolską „Christus Dominus" (przekł. ks. Tadeusz Szwagrzyk). 1 (1957) 60-61 
— Z encykliki „Divino afflante Spiritu”. 1 (1948) 4-5

STOLICA APOSTOLSKA, Dekret o wprowadzeniu konstytucji „O liturgii świętej” w życie. 3 (1964) 174

Wyjaśnienie nowego kodeksu rubryk (przekł. o. Franciszek Małaczyński OSB). 5 (1961) 262-263

\section{BIBLIOGRAFIE}

Bibliografia artykułów biblijnych pomieszczonych w dwumiesięczniku „Ruch Biblijny i Liturgiczny" 1948-1982 (oprac. seminarium naukowe hermeneutyki biblijnej). 2 (1984) 161-181

Bibliografia biblijna. 1 (1949) 70-72

Bibliografia publikowanych prac o. dra Franciszka Małaczyńskiego OSB. 1-2 (1990) $2-5$

Bibliografia prac ks. biskupa prof. dra Andrzeja Wronki. 4 (1973) 174-176

GOŁĘBIEWSKI Marian ks., Bibliografia prac prof. Franciszka Jóźwiaka. 1 (1989) 7072

GRZYBOWSKI Michał Marcin ks,. Bibliografia publikacji ks. Konrada Gąsiorowskiego. 4 (1983) 339-341

HOMERSKI Józef ks., Bibliografia prac o. L. Semkowskiego SJ. 6 (1977) 340-342

JABŁOŃSKI Zachariasz OSPPE, Wykaz publikacji o. dra Rufina Abramka OSPPE. 1 (1995) 66-72

KAPERA Zdzisław, Bibliografia prac księdza Aleksego Klawka (1890- 1969) profesora UJK i UJ. 6 (1970) 319-336

- Uzupełnienie do bibliografii prac ks. Aleksego Klawka. 4 (1980) 227-232

KIEŁBASA Antoni SDS, Bibliografia publikacji ks. Jana Drozda SDS (1936-1995). 3 (1997) 218-222

KIERSTAN Janina RM, Bibliografia publikacji ks. prof. dra Michała Petera (19581982). 1 (1983) 41-51

KOWALSKI Jan ks., Bibliografia prac ks. dra Ferdynanda Machaya (w zarysie). 4-5 (1967) 202-209

KUBIŚ Adam ks., Bibliografia prac ks. prof. dra Eugeniusza Florkowskiego. 1 (1976) 8-9

LENART Emilian OFM, Bibliografia prac ks. dra Wojciecha Danielskiego. 5 (1986) 420-430

MAŁECKI Zdzislaw, Bibliografia ks. prof. dra Aleksego Klawka. 1 (1963) 10-15 
MATRAS Tadeusz ks., Bibliografia prac publikowanych ks. prof. dra hab. Stanisława Grzybka. 5 (1980) 291-297

- cz. II (1981-1995). 1 (1996) 63-67

- Bibliografia publikacji ks. prof. Władysława Smereki. 6 (1981) 344-346

- Bibliografia prac publikowanych ks. bpa Tadeusza Szwagrzyka. 2 (1993) 106-108

- Prace drukowane o. profesora Augustyna Jankowskiego OSB na łamach Ruchu Biblijnego i Liturgicznego. 1 (1997) 64-65

- Przegląd bibliograficzny. 2 (1983) 191-192; 1 (1984) 94-96; 1 (1985) 8687; 1 (1986) 85-88; 1 (1987) 93-95; 2 (1987) 183; 4 (1988) 366-367; 6 (1988) 535-536; 2 (1989) 157-159; 3-6 (1990) 182-184; 1-3 (1991) 8385 ; 4-6 (1991) 162-166; 1 (1992) 49-51; 2-6 (1992) 110-111; 1 (1993) 5153; 3-4 (1993) 195-197; 1 (1994) 67-69; 2 (1994) 137-140; 4 (1995) 304307; 2 (1996) 142-145; 3 (1996) 218; 4 (1996) 283-285; 2 (1998) 155-157

MĘDALA Stanisław CM, Publikacje ks. J. Stępnia w zakresie biblistyki. 2 (1995) 146148

PILARCZYK Krzysztof, Ewangelia i Dzieje Apostolskie św. Lukasza. Bibliografia publikacji w Polsce za lata 1945-1985. 6 (1986) 504-530

Polska bibliografia mariologiczna okresu powojennego. 1 (1956) 142-144

RUMIANEK Ryszard ks., Publikacje naukowe ks. prof. dra hab. Czesława Jakubca. 1 (1994) 61-62

SALOMON Adam OFMConv, Publikacje naukowe o. prof. Józefa W. Rosłona. 1 (1996) 60-62

SULOWSKI Julian SJ, Bibliografia publikacji ks. Alfreda Cholewinskiego SJ. 5-6 (1989) 395-396

TRONINA Antoni ks., Bibliografia publikacji ks. prof. L. R. Stachowiaka. 4 (1997) 299-308

WOLNIEWICZ Marian ks., Bibliografia prac drukowanych ks. Felicjana Kłonieckiego. 4-6 (1991) 153-156

Wykaz autorów. 6 (1959) 640-644

Wykaz treści „Ruchu Biblijnego i Liturgicznego” (1948-1957). 6 (1959) 605-640

\section{TEKSTY OGÓLNE}

Błogosławieństwo prymasowskie. 4-5 (1956) 185

Hołd Polskiego Towarzystwa Teologicznego w Krakowie dla papieża Jana Pawła II. 1 (1979) 2 
Hymn do Ducha Świętego (przekł. o. Stanisław Foryś CSSp). 6 (1972) 358-360

Hymn na święto Matki Bożej Częstochowskiej. 4-6 (1959) 208-209

Komunikat Wydawnictwa Pallottinum. 1 (1984) 93

Krucjata Modlitwy w obronie poczętych dzieci. 2 (1984) 188

Ks. Jakub Wujek w opinii wieków (zestawił ks. Aleksy Klawek). 1-2 (1950) 16-23

List gratulacyjny ks. kard. F. Macharskiego dla RBL. 4 (1998) 250

List Walnego Zebrania Polskiego Towarzystwa Teologicznego w Krakowie do papie ża Jana Pawła II. 2 (1991) 133

Liturgia pogrzebu ks. W. Danielskiego. 5 (1986) 434-435

Liturgia Słowa. Modlitwa za pomordowanych Żydów. 4 (1983) 342-344

Modlitwa powszechna na Mszy św. o pojednanie w Oświecimiu-Brzezince. 1 (1980) 44

Modlitwa powszechna na Mszy św. odprawianej na zakończenie Duszpasterskiego Synodu Archidiecezji Krakowskiej. 1 (1980) 45

Modlitwa powszechna na Mszy św. o N. Maryi Pannie Matce Kościoła w Nowym Targu. 1 (1980) 46

Myśli o św. Pawle w „Quo vadis” Sienkiewicza. 1 (1953) 167-172

Odpowiedź Sekretariatu Stanu na list PTT. 1 (1979) 3

Officjum nowe na dzień Wniebowzięcia MB. 1 (1951) 8-9

Oświadczenie Episkopatu Polski. 4 (1952) 377

Oświadczenie w sprawie zajść krakowskich. 4 (1952) 377

RICCI Katarzyna św., Misterium o Męce Pańskiej (przekł. ks. Aleksy Klawek). 2 (1948) 52-54

SKWARNICKI Marek, Hymn ku czci św. Stanisława. spec (1979) 96

SKWARNICKI Marek, Modlitwa za Jana Pawła II. spec. (1979) 96

SKWARNICKI Marek, Pieśń o błogosławionej Jadwidze królowej. 1 (1980) 48; spec. (1979) 97

SKWARNICKI Marek, Pieśń do św. Jana Kantego. spec. (1979) 97

Telegram Jana Pawła II do Metropolity krakowskiego po powrocie do Rzymu. 1 (1980) 47

Wielkie antyfony adwentowe (przekł. Maria Turska). 5-6 (1948) 272-275

Uchwała Walnego Zebrania Polskiego Towarzystwa Teologicznego w Krakowie w sprawie Papieskiego Wydziału Teologicznego w Krakowie. 2 (1981) 133 


\section{TEKSTY BIBLIJNE}

Błogosławieństwo umierającego Jakuba - Rdz 49,1-28. (przekł. ks. Aleksy Klawek). 1 (1953) 1-3

Bóg wszechobecny i wszechwiedzacy — Ps 139 (przekł. ks. Aleksy Klawek). 3 (1952) 193-194

Chrystus stworzyciel i zbawiciel świata - Hbr 1, 2-5, 10 (przekł. ks. Aleksy Klawek). 5-6 (1948) 267

De profundis — Ps 130 (przekł. ks. Jakub Wujek i inni). 1-2 (1950) 3-6

Dwie pieśni Izajasza: Gród Boży 26, 1-6; Tęskonota za pokojem 26, 7-19 (przekł. ks. Aleksy Klawek). 3-4 (1950) 161-162

Ecce Homo - J 19, 5-6; Iz 53,1-12 (przekł. ks. Aleksy Klawek). 2 (1949) 73-74

Elegia Dawida - 2 Sm 1,17-27 (przekł. ks. Aleksy Klawek). 3-4 (1950) 163

Ewangelia na Zielone Swiątki — J 14, 23-31 (przekł. ks. Jakub Wujek). 1 -2 (1950) 1-3

Incipit Lamentatio Jeremiae prophetae — Lm 3 (przekł. ks. Aleksy Klawek). 2 (1949) $75-76$

Iz 58, 1-12 (przekł. ks. Aleksy Klawek). 1 (1952) 4-5

Jezus w Nazaret (Łk 4, 16-23). 3 (1949) 148

Kim jest Chrystus? - Kol 1, 13-21; Ap 19 (przekł. ks. Aleksy Klawek). 1 (1949) 1-3

Któż jak Bóg — Iz 40, 12-31 (przekł. ks. Aleksy Klawek). 3 (1949) 145-146

Królestwo synów bożych — Iz 61 (przekł. ks. Aleksy Klawek). 3 (1949) 147-148

Krótkie teksty biblijne ku czci Najświętszego Serca Pana Jezusa. 3 (1949) 209-211

Modlitwa niewidomego. 4 (1978) 214

Modlitwa pokutna Azariasza - Dn 3, 24-45 (przekł. ks. Aleksy Klawek). 2 (1951) 145-147

Modlitwa Ezechiasza — Iz 38, 1-20 (przekł. ks. Aleksy Klawek). 3 (1951) 241-243

Modlitwa o mądrość (Sap 9, 1-17). 3-4 (1948) 122-123

Modlitwa na poświęcenie Przybytku Pańskiego - 1 Kr 18 (przekł. ks. Aleksy Klawek). 4 (1949) 225-227

Modlitwy pokutne - Mdr 15,1-3; Łk 18, 13; 23, $41-42$ (przekł. ks. Aleksy Klawek). 2 (1951) 146-147

Myśli o pasterzu i pasterzach. 2 (1955) 131-134

Obietnica pokoju — Iz 57,14-21 (przekł. ks. Aleksy Klawek). 1 (1952) 1-2

Obraz winnicy Pańskiej — Iz 5, 1-7 (przekł. ks. Aleksy Klawek). 5-6 (1950) 253-254

Pieśn ku czi Stworzyciela - Syr 42, 15 - 43, 33 (przekł. ks. Aleksy Klawek). 4-6 (1951) 329-332 
Postem Bożym — miłosierdzie — Iz 58, 1-12 (przekł. ks. Aleksy Klawek). 1 (1952) 2-

3; (przekł. ks. Jakub Wujek) 1 (1952) 4-5

Potęga Jahwe gromowładnego. 1 (1955) 37-39

Prymat miłości bliźniego - 1 Kor 13 (przekł. ks. Aleksy Klawek). 4 (1948) 193-194

Przepowiednia o królestwie pokoju — Iz 11, 1-9 (przekł. ks. Aleksy Klawek). 5-6 (1948) 265-266

Przepowiednia o upadku Babilonu — Iz 14, 3-23 (przekł. ks. Aleksy Klawek). 4 (1948) 194-195

Przepowiednia Zachariasza o przybyciu Chrystusa Króla - 9, 9-10 (przekł. ks. Aleksy Klawek). 5-6 (1948) 266-267

Przepowiednie Izajasza o wyzwoleniu - Iz 8, 23 - 9, 6 (przekł. ks. Aleksy Klawek). 5-6 (1948) 265

Przykłady pokory: Sdz 9; Flp 2; Ap 22, 8; Łk 18, 9 -14; 1 P 5, 5 (przekł. ks. Aleksy Klawek). 6 (1949) 377-379

Psalm 67/68 (przekł. ks. Aleksy Klawek). 1 (1956) 24-26

Słowa pociechy: Iz 41, 9-20; 66, 9-14 (przekł. ks. Aleksy Klawek). 1 (1949) 2-3

Słowo Boże. 1 (1948) 3-4; 3 (1948) 121-122

Szukajcie Pana: Iz 55 (przekł. ks. Aleksy Klawek). 4-6 (1950) 259-260

Śmierć Mojżesza - Pwt 32,48-52; 34, 1-12 (przekł. ks. Aleksy Klawek). 2 (1952) 9798 (Parafraza tekstu według Kornela Ujejskiego. 2 (1952) 98-100)

Te Deum Starego Przymierza — Ps 148 (przekł. ks. Aleksy Klawek). 1 (1964) 3-4

Teksty maryjne (przekł. ks. Aleksy Klawek). 1 (1951) 1-7

Upomnienia życiowe: Rz 12,1-21; Tb 4, 3-19; Prz 6, 6-11 (przekł. ks. Aleksy Klawek). 4 (1952) 281-284

Viderunt in quem transfixerunt - J 19,37; Za 12, 10 (przekł. ks. Aleksy Klawek). 2 (1949) 74-75

Widzenie Izajasza syna Amosa — Iz 1, 1-19 (przekł. ks. Aleksy Klawek). 2 (1948) 3941

Wizje zmartwychwstania (Ez 37, 1-14; Iz 26, 19). 5 (1949) 308-309

Z księgi Hioba (7, 16-21; 10, 1- 12. 18-22; 13, 22-28; 17, 1-3. 11-15; 19, 20-27). 5 (1949) 305-308

Kraków

KS. TADEUSZ MATRAS 